\title{
The Portrayal of the Germani in German Latin Textbooks
}

\author{
James McNamara
}

Submitted in fulfilment of the requirements for the degree of Master of Arts in Classics

Victoria University of Wellington

2008 
For Angharad. 


\section{Acknowledgements}

Thanks are due to a large number of people who have made it possible to produce this thesis.

First of all I would like to thank the Classics Department at Victoria University, who have helped me in innumerable ways leading up to and during this research. In particular I thank my supervisors, Professor Arthur Pomeroy and Dr. Babette Pütz, who were generous with their time and offered invaluable guidance and countless helpful suggestions along the way.

During the time I spent in Germany in 2007 I received generous help from a number of people. Without the friendly guidance of Professor Stefan Kipf of the Freie Universität and Humboldt Universität in Berlin, this topic would never have taken shape as it did. It was Professor Kipf who alerted me to the possibility of making textbooks the focus of my research. I would like to thank him and the curators of the excellent textbook collections of FU and $H U$. Thanks also to Professor Andreas Fritsch of FU, whom I did not meet but who allowed me to access some books in his own collection.

Thanks also to Dr. Josef Rabl, Chair of the Deutscher Altphilologenverband in Berlin and Brandenburg, who provided me with contacts among Latin teachers in Berlin and offered numerous helpful suggestions through e-mail correspondence and in person. I appreciate the information and personal reflexions that a number of Latin teachers have shared with me. Thanks in particular to Gottfried Schwemer and Dr. Gottfried Bloch (both of Tübingen) for their correspondence, to Jens Augner and Dietrich Stratenwerth (Berlin). I am particularly grateful to Jörg and Monika Dietrich for their hospitality in decumatibus agris.

I would like to express my gratitude to a number of other people who helped me in or from Germany: Professor Hans-Joachim Glücklich (Frankfurt a.M.) who has engaged in friendly and helpful correspondence via e-mail; Dr. Michael Zelle and his team at the Lippisches Landesmuseum Detmold who gave their time to discuss their upcoming exhibition programme; Stefan Mischer, who discussed his film Die Hermannsschlacht with me, Jonas Zipf of HermannScblachten07, Stuttgart; Hans Rübesame of the Deutsches Theater (Berlin); Jordin Tahana, Thomas Bleskin and Agnes Brandt who made sure I had accommodation in Berlin.

Thank you to Dr. Heidrun Schweinfurth-Marby, an old family friend, whose voracious reading of the $F A Z$ provided me with some valuable leads and who, together with her late husband Professor Ulrich Schweinfurth, did much to pique my interest in Germania Romana before I ever learnt Latin.

Thanks to Dr. Margaret Sutherland of the Victoria University German Department for generously offering her time to discuss various aspects of the topic and her experiences researching in Germany, and to Anke Szczepanski for kindly helping me to draft and proofread a number of documents in German. Thanks also to Professor Hansgerd Delbrück. her library.

Monika Smith has generously provided me with helpful observations and with books from

I would like to thank the participants in the 2007 AMPHORA conference at the University of Queensland and the Australasian Society for Classical Studies conference in Christchurch, 2008, for their feedback and encouragement.

I wish to acknowledge the generous support I have received in the form of scholarships and grants: a Masters by Thesis Scholarship from Victoria University and a Freemasons New Zealand Postgraduate Scholarship allowed me to devote myself to study full time and to conduct essential research overseas. Carrying out research in Germany on this topic was also assisted by a New Zealand Postgraduate Study Abroad Award.

Thanks to all my friends who have variously shown interest and empathy, have helped and diverted me and generally kept me happy!

My family have supported me wonderfully well throughout the course of this project (and, indeed, through all the time before it). They have devoted time, love and effort in too many ways to mention and so I thank them lovingly. 


\section{Contents}

$\begin{array}{ll}\text { Abstract } & 5\end{array}$

$\begin{array}{ll}\text { Abbreviations } & 6\end{array}$

$\begin{array}{ll}\text { Introduction } & 7\end{array}$

I The Kaiserreich: Ostermann's Übungsbucb 13

II The Weimar Republic: Ludus Latinus 24

III The Third Reich 36

IV The years 1945-1970 51

V The years 1970-2007 63

$\begin{array}{lr}\text { Conclusion } & 89\end{array}$

Appendix - The Germani in schoolbook illustrations 94

$\begin{array}{ll}\text { Bibliography } & 102\end{array}$ 


\section{Abstract}

This study investigates the ways in which the Germani have been portrayed in textbooks used for teaching and practising the Latin language in schools in Germany from 1872 to 2007. It is a contribution to the reception history of Roman ethnographic and historical writing about the Germani, especially Tacitus' Germania, but also Tacitus' Annals and Histories, and Caesar's Gallic War.

The study also provides a perspective on the place of classics in education and society at large since the 1870s. Concentration on Germany has been necessary for the sake of time, space and thoroughness, though many of the trends discussed are related to developments in other countries or are indicative of broader trends across Europe.

The first chapter discusses Christian Ostermann's textbooks from Prussia in the late $19^{\text {th }}$ century. The content of these textbooks' practice sentences often reflects Nationalist trends in German society and the education system. In the second chapter the influential Ludus Latinus series represents the Weimar Republic. The series attempted to make Latin appealing to young learners and also shows the influence of the Kulturkunde theory, which made understanding of German culture the centre of the education system. In the third chapter the influence of National Socialism on Germany's education system is discussed with reference to a variety of textbooks of the period from 1938 to 1945 . During this period, under the influence of racial ideology, nationalistic interpretations of ancient history and the close identification of Deutsche with Germani reached an extreme.

Chapter four deals with the years from 1945 to 1970. After 1945, associations with the ideology of National Socialism made Germania and the Germani unpopular topics. Latin and Greek also became unfashionable subjects and experienced a 'crisis' from which they only slowly recovered due to radical reforms in the methodology of ancient language teaching (described in chapter 5), including the production of textbooks that aimed at providing greater understanding of the ancient world and challenged long-entrenched stereotypes. Public interest in Germany's ancient heritage (both Roman and Germanic) has increased in recent decades, and the content of textbooks reflects this trend. In addition, the process of European unification has led to new perspectives on the ancient world and its relevance to modern Germany and Europe as a whole. 


\section{Abbreviations}

\section{See bibliography for further information about textbooks.}

Caes. $B G$

EL

EUhS

FAZ

FLL

Frankfurt a.M.

LL

Lat. Unt. Bornemann

Lat. Unt. Krüger

Lat. Unt. MW

Lat. Üb. Ost.

Lat. Üb. Ost.-M.

Tac. Ann.

Tac. Ger.

Tac. Hist.

$T A Z$

Vell. Hist.
Caesar, De Bello Gallico

Exercitium Latinum, Lese- und Übungsbuch, Röttger, G. (1941)

Leipzig/Berlin.

Erziebung und Unterricht in der böheren Schule. Amtliche Ausgabe des Reichs- und Preußischen Ministeriums für Wissenschaft, Erziehung und Volksbildung (1938) Berlin.

Frankfurter Allgemeine Zeitung

Fundamenta Linguae Latinae, Lateinisches Lehr-und Lesebuch (I A für die dritte Klasse der Oberschule), L. Voit, Zinsmeister, H. ( $\left.{ }^{5} 1942\right)$ Bamberg/Munich/Berlin/Reichenberg.

Frankfurt am Main

Ludus Latinus, (various versions and editions). For example, (LL I ${ }^{8} A$, iii) refers to Ludus Latinus, part I, version A (outside Bavaria), eighth edition; page iii.

Lateinisches Unterrichtswerk, Bornemann, E. (various versions and editions; see $L L$ for notation).

Lateinisches Unterrichtswerk, Krüger, M., (various versions and editions; see $L L$ for notation).

Lateinisches Unterrichtswerk, Mader, L., Wecker, O. (various versions and editions; see $L L$ for notation).

Lateinisches Übungsbuch im Anschluß an ein grammatikalisch geordnetes Vocabularium, erste Abtheilung für Sexta, Ostermann, Christian ( $\left.{ }^{8} 1872\right)$ Leipzig.

Lateinisches Übungsbuch (I: Sexta), Ostermann, C., Müller, H. ed. (51896) Leipzig.

Tacitus, Annals

Tacitus, Germania

Tacitus, Histories

Die Tageszeitung, Berlin

Velleius Paterculus, History of Rome 


\section{Introduction}

This study investigates the ways in which the Germani have been portrayed in textbooks used for teaching and practising the Latin language in schools in Germany from 1872 to 2007. ${ }^{1}$ It is a contribution to the reception history of Roman ethnographic and historical writing about the Germani, especially Tacitus' Germania, but also Tacitus' Annals and Histories, and Caesar's Gallic War. ${ }^{2}$

Existing research into German Latin textbooks includes Gisela Müller's 1975 dissertation, which examines a large sample of the approximately 100 different textbooks that were used in Germany during the $19^{\text {th }}$ century. Müller analyses methodological developments as well as the attempts to introduce pupils to the ancient world and ancient thought which resulted in "Erstarrung im patriotisch-moralisierenden Klischee". ${ }^{3}$ Ernst Habenstein briefly discusses his personal experiences with textbooks from before the First World War until just after the Second World War. ${ }^{4}$ Andreas Fritsch has carried out research on the role and content of Latin passages in textbooks - providing an overview from the early $19^{\text {th }}$ century until the mid 1970s - and on the role of Sachkunde (often referred to in English as historical and cultural 'background information') in the early stages of school Latin. ${ }^{5}$ Much of this research into the history of ancient language teaching has been motivated by the need to confront the implications of classical philology and ancient language teaching under the Third Reich. Fritsch has paid particular attention to the methodology and subject matter of textbooks of that period. ${ }^{6}$ Klaus-Dieter Thieme published a strongly-worded critique of conservative ideology in traditional textbooks in the late 1960s. ${ }^{7}$ Recently, Stefan Kipf's study of ancient language teaching (particularly Latin) since 1945 has included thorough

\footnotetext{
${ }^{1}$ The years 1872 and 2007 are the publication dates of the oldest and newest textbooks here examined. For the sake of variation the word 'coursebook' will sometimes be used.

${ }^{2}$ Narratives of the battle in the Teutoburg Forest tend to rely on a combination of sources, primarily Cassius Dio's Roman History, Velleius Paterculus' Roman History and Tacitus' Annals. Some points of diction should be clarified immediately. 'Germani' are those people described by the Romans as 'Germani', while 'Germans' are those who identify themselves as 'Deutsche'. Similarly, the adjective 'Germanic' will either be used to describe that which pertains to the Germani or in places where its usage is standard (for example, in the term 'Germanic languages'). 'German' will be used where 'deutsch' would be appropriate. 'Germania' (italicised) denotes Tacitus' work De origine et situ Germanorum, while 'Germania' (not italicised) describes the area inhabited by the Germani and known to the Romans as 'Germania'.

3 Müller (1975), 190.

${ }^{4}$ Habenstein (1963).

${ }^{5}$ Fritsch $(1976,1978,1991)$.

${ }^{6}$ Fritsch (1982). Nickel $(1972,1984)$ bases his research into the Humanist Gymnasium under the Third Reich on political documents and the writings of educationists.

7 Thieme (1969).
} 
surveys of textbooks in the period 1945-2006 and analysis of methodology, subject matter and, importantly, implicit or explicit justifications for teaching Latin. ${ }^{8}$

The portrayal of the Germani is discussed, in most instances briefly, in a number of the studies mentioned above, though there are no investigations into the history of how the Germani have been portrayed in textbooks - the thread which this thesis follows from Christian Ostermann's books which dominated the scene at the time the second German Reich was founded through to new publications of 2006 and 2007. The time-span examined requires the selection of representative textbooks from each period. A related question is how Germania and other Latin works involving the Germani (particularly excerpts from Caesar's Gallic War) have been received in the upper classes of school where original Latin texts are read (often called the Lektürephase). Whereas Caesar became synonymous with the subject of Latin in the $19^{\text {th }}$ century in many countries, the prominence of Tacitus' Germania is unique to German-speaking Europe.' It is outside the scope of my investigation to deal in depth with the history of Germania as a school text, but relevant aspects will be discussed briefly in each chapter.

A particular focus of this thesis is the portrayal of the Germani after the Second World War, a period usually mentioned only fleetingly in reception histories of Germania or dismissed on the grounds that there is not much to say. ${ }^{10}$ The appropriation of the text by the racist ideologies of the Third Reich has meant that the text which, over the centuries, has exerted an influence on German national identity and self-image greater than any other is of very little importance for politics and national identity today. For some decades after the Second World War, academic interest in Germania was minimal. Nevertheless, the Germani have always been included in most school Latin textbooks to a greater or lesser extent and, since the 1980s, academic, artistic, political and economic interest in the ancient inhabitants of Germany has increased considerably. School remains the most common place for Germans to encounter ancient descriptions of the Germani, both through the

\footnotetext{
${ }^{8}$ Kipf (2006), 54-79, 280-340.

9 The remarkable uniformity of the canon of school authors across Europe is discussed by Waquet with examples from the seventeenth to the mid-20 th century. Although Tacitus' other works are mentioned, Germania is absent (Waquet (2001), 33-34). For Caesar as an author synonymous with school Latin in Germany see Kipf (2006a), 28-46. Just as Germania has been widely read in German schools, the geographical and national relevance of Caesar's invasion of Britain (Caes. BG 4.20-5.23) and Tacitus' Agricola have often made them popular choices for reading in British schools. See, for example, Caesar's Invasions of Britain [Gallic War, Book IV, ch. 20-Book V, ch. 24], Carrington, R. ed., (1945) London, and Experientia. A Modern Practice Book for "O” Level Latin, Morris, S., ed. (1957) London/Toronto/Wellington/Sydney, the greater part of which presents stories from Roman Britain, and narratives and speeches relating to British history through the ages up to the 1950s. Textbooks are listed in section V of the bibliography, arranged by title.

10 About half of this thesis deals with the years 1945-2007.
} 
continuing presence of Caesar and Tacitus in Lehrplänen and - even more commonly through adaptations of ancient sources in textbooks.

Researching didactic history presents a number of particular difficulties. Official policies and regulations indicate what schools should be teaching, but reconstructing what happened in the classroom is more difficult because in the absence of empirical research we have to rely on personal recollections and often scant documentation such as inspectors' reports and lesson plans - all of which may be misleading or biased to a degree which is often hard to determine. The main primary sources for this investigation are textbooks, most of which were produced for use in Humanist Gymnasien, though a number of books for other types of school are included from the time of the Third Reich onwards. ${ }^{11}$ Andreas Fritsch observes that school textbooks (Schulbücher) can be regarded as "konkretisierte Lehrpläne", that is, concrete manifestations of the regulations and guidelines set down by educational authorities. He also observes that they can often be regarded as "[die] wirkungsmächtigsten Curricula" or "die eigentliche Großmacht der Schule", not merely acting as guides for the teaching process but actually determining the teaching methods, content, emphasis and boundaries of the subject. ${ }^{12}$ It is not my intention to reconstruct the world of past classrooms through this investigation, but instead to examine a thread through the history of the textbooks used in schools and the ways it reflects political, social and educational developments in Germany. ${ }^{13}$ Rather than providing an unbroken history of the subject over the period covered, the thesis will tend to concentrate on textbooks that show developments in the portrayal of the Germani. ${ }^{14}$

In the early $16^{\text {th }}$ century, two particularly influential interpretative trends became established amongst Humanist readers of Tacitus' Germania: the contemporary Deutsche were considered unreservedly to be the descendents of the Germani (who thus became early Deutsche), and their character traits came to be regarded as a 'canon' of eternal German

\footnotetext{
11 The history of textbooks presents its own difficulties as they tend to be discarded once they have outlived their usefulness in the classroom. My study is based on textbooks obtained from acquaintances and from libraries, particularly the excellent collections at the Freie Universität and Humboldt Universität in Berlin. Previous research into the history of textbooks (see above) has provided valuable information as well.

12 Fritsch in: Landfester (1999), 1101.

${ }^{13}$ Hans-Jürgen Apel and Stefan Bittner (1994) have assessed not only official teaching plans (Lehrpläne) but also school inspectors' reports and a variety of documentation from teachers' colleges and schools from the period 1890-1945 in the Rhine Province (a Prussian province made up of parts of present-day North-Rhine Westfalia, Rhineland-Palatinate and Hesse). I have made use of some of their findings regarding the use of Germania as a set text. Their emphasis is on the reading of ancient texts in the later school classes rather than the language-learning phase during which textboooks are used.

14 The First World War, for example, undoubtedly had a strong impact on the classroom reality of school Latin but it was not a catalyst for the production of new textbooks for linguistic instruction and thus the war itself is absent from this thesis. The effects of the war on German self-image and mythology are, however, important and its contribution to the 1924/1925 Gymnasialreform and the Kulturkunde movement are the focus of considerable attention (see chapter 2).
} 
characteristics. ${ }^{15}$ Such misconceptions exerted a strong influence on popular and academic interpretation of Germania until the end of the Second World War.

Klaus von See describes a set of characteristics that make up what he calls the "Lesebuchgermanen" - a positive stereotype of the Germani, based primarily on selective reading of Tacitus' Germania:

...rauh und kriegerisch gesinnt und dabei offenherzig und bieder, den althergebrachten, bäuerlich-bodenständigen Sitten verhaftet, von keuscher, schlichter Ehrbarkeit in der Acbtung der Frau und des Gastfreundes, abgeneigt dem Händler- und dem Advokatentum, im politischen nicht institutionell-etatisch denkend, sondern auf die natürlichen, gewachsenen Gemeinschaften von Familie, Sippe und Stamm bauend und auf die persönliche Treuebindung zwischen Gefolgsherr und Gefolgsmann. ${ }^{16}$

Other characteristics such as patriotism, piety and common sense are variously included in different descriptions. ${ }^{17}$ Patriotism in particular, it shall be shown, was a persistent characteristic of the Germani in traditional textbooks. ${ }^{18}$ The basic characteristics of the "Lesebuchgermanen" are more or less identical with the characteristics of what we might call "Lehrbuchgermanen" (figure 1 in the appendix shows a late $19^{\text {th }}$ century schoolbook illustration that exemplifies stereotypical Lesebuchgermanen). The stereotype persisted essentially unchallenged in Latin textbooks from the time of Ostermann's Übungsbücher (the earliest here examined) until it finally began to be challenged and revised from the 1970s onwards. The traditional Germanic stereotype was defined by its polar opposition to a negative Roman stereotype:

...überspitzt formuliert: treu, gemütvoll, leidenschaftlich, sittengebunden ist der eine, weil der andere ökonomisch, rational, kühl, individualistisch ist. ${ }^{19}$

\footnotetext{
15 Von See (1970), 11. Fuhrmann (1977), 73. The Germani were often considered, in Germany, to be the ancestors of the Germans exclusively (Römer (1989), 88).

16 Von See (1970), 9.

17 'Common sense' is very much an English turn of phrase, but it is used here to describe various chracteristics such as what Herder, cited by Muhlack (1989), 145, called "Zutrauen auf Verstand" and Ostermann (1872), 13, called "ein gesunder Sinn" (see chapter 1 for reference to this sentence from Ostermann's Lateinisches Übungsbuch).

18 The term 'traditional' will be used in the following to refer to textbooks from Ostermann's Lateinisches Übungsbuch until the 1970s when the concept of a Latin textbook changed dramatically. The designation 'traditional' is justified due to the consistency of the textbook format and many features of the Germanenbild over this period.

${ }_{19}$ Von See (1970), 10.
} 
Although many features of Germanic (and associated Roman) cliché were influential in traditional textbooks, the stark antithetical model was somewhat tempered in the school context. Humanist Gymnasien (and Latin teaching in other schools) were founded on admiration for Greek and Roman antiquity. Latin textbooks are certainly not the place for an anti-Roman world view, and admiration for Roman achievements could be expected to bring with it disdain for the primitive Germani. In fact, the characteristics often claimed as uniquely Germanic were for the most part generic barbarian topoi as Roman authors such as Tacitus and Caesar were working in an ethnographic tradition largely based on what Eduard Norden called "ethnographische Wandermotive". The opposition of civilised autostereotype (Greek, Roman or Greco-Roman depending on the author) and barbarian heterostereotype was itself a topos, and heterostereotypes in particular were often constructed largely out of barbarian $W$ andermotive or clichés well established in the tradition. $^{20}$

In the context of the "didaktisches Dreieck" of academia, society and pupils, which determines the nature of the educational system and thus the content of textbooks, "Lebrbuchgermanen" served a variety of purposes during the more than 100 years here examined. ${ }^{21}$ Until the end of the Second World War, political correctness required that the Gymnasium, particularly the Humanist Gymnasium, prove itself sufficiently national. The extremity of Deutschtümelei under the Third Reich and its contribution to racist ideology and warmongering meant that nationalism was no longer an acceptable justification for including a large amount of Germanic and modern German material in Latin textbooks after 1945 .

From 1945 until 1990, the division of Germany (into, from 1949, the German Democratic Republic and the Federal Republic of Germany) meant that there were two distinct school systems operating. This study, however, follows developments in the Federal Republic of Germany rather than the German Democratic Republic. The chief reason for doing so is that the government of the GDR deliberately marginalised ancient language teaching, viewing it as bourgeois and elitist. ${ }^{22}$ The significance of the theme of Germani is therefore slight when the subject as a whole was marginalised to such an extent. Developments in Latin teaching and textbook production since 1990 have been based on the tradition of ancient language teaching in West Germany, which was relatively much stronger.

\footnotetext{
${ }^{20}$ Lund (1991), 1958-1961. Norden (41959), 58: "Die germanische Ethnographie hat zeitlich fast am Ende einer sebr langen Reihe gestanden: daher ist sie von völkerkundlichen Wandermotiven wie übersät."

${ }^{21}$ For the "didaktisches Dreieck" see Kipf (1999), 2-5.

22 Fischer (1974), 5.
} 
Many of the textbooks here examined were published for use in Humanist Gymnasien (bumanistische Gymnasien), a kind of school founded in Prussia after J.W. Süvern's educational reform of 1816. They were the flagship representatives of Neubumanismus, a philosophy of general education championed by Wilhelm von Humboldt (who paved the way with his educational reform of 1809). Neuhumanismus was centred on engagement with the literature of the ancient world, especially Greece. Its purpose was the general education of the individual, whose intellectual capabilities would be developed towards a capability for independent thought and understanding of the good and the beautiful. The aim was to produce socially responsible and intellectually versatile thinkers. Of the planned 320 Wochenstunden (the sum of the hours-per-week during a pupil's nine years at the Gymnasium), 78 were allotted to Latin, 50 to Greek, 44 to German and 60 to mathematics. ${ }^{23}$ Pupils usually began at the Gymnasium at the age of 10 in the class known as Sexta. There followed Quinta, Quarta, Untertertia, Obertertia, Untersekunda, Obersekunda, Unterprima and Oberprima. Today these year levels are more often known as 5.-13. Klasse. ${ }^{24}$ Latin was taught as the first foreign language in a nine-year-long course from Sexta, a model that continues to operate in some Gymnasien today, though this is no longer the norm for school Latin. Gymnasien today may have a scientific, modern language, musical or ancient language focus. ${ }^{25}$ Years 5 and 6 are today sometimes known as the Orientierungsstufe, while years 7-10 are known as Sekundarstufe I and years 11-13 as Sekundarstufe II or the Oberstufe. Abitur is the name of the university entrance qualification that can be attained at the end of one's secondary schooling. Germany's constituent states have always regulated their own school systems and there has always been a certain amount of regional variation. The textbooks examined have mostly been used across numerous states, however, and the conclusions drawn are of relevance to most, or much, of Germany if not all. Further relevant details about the school system will be included in each chapter as required.

23 Apel in: Landfester (1999), 563-565.

24 5. Klasse, 6. Klasse will henceforth be translated as 'year 5', 'year 6' and so forth.

25 Glücklich in: Bulwer (2006), 58-9. 


\title{
I The Kaiserreicb: Ostermann's Übungsbucb
}

The teaching of Latin in schools up till the $17^{\text {th }}$ and $18^{\text {th }}$ centuries must be seen against the background of the fact that Latin was used across Europe as the language of scholars, of law, diplomacy and the Catholic Church. In the Renaissance, schools aimed at teaching "Latine legere, scribere, loqui". ${ }^{26}$ As Latin became less widely used, sheer utility was not enough to justify its being taught in schools. Instead of declining, however, Latin enjoyed a privileged position in $19^{\text {th }}$ century schools across Europe with an aura of what Françoise Waquet (writing about France, but with relevance to Europe generally) calls "royal grandeur". ${ }^{27}$ Throughout Europe Latin was "the distinguishing mark of educational establishments for the elite". ${ }^{28}$

In Germany, the Neubumanismus movement, generally associated with the years 1790-1830, boosted enthusiasm for Latin in schools. It was a movement focused primarily on Hellenic culture of the $5^{\text {th }}$ and $4^{\text {th }}$ centuries BCE, though Latin was always, and still is, introduced to school pupils earlier than Greek and had more teaching hours allotted to it. The aim of Neubumanismus was the general education (Allgemeinbildung) of the individual, who was to be educated towards autonomy and the unfolding of innate intellectual capabilities. ${ }^{29}$ In a speech of 29 September 1809, Wilhelm Friedrich Hegel, rector of the Gymnasium in Nürnberg, says that children need the material which they study to be "eine Nabrung", which excludes everyday material of the sort that readily fits in with the child's conception of the world.

\begin{abstract}
Nur der geistige Inbalt, welcher Wert und Interesse in und für sich selbst hat, stärkt die Seele und verschafft diesen unabhängigen Halt, diese substantielle Innerlichkeit, welche die Mutter von Fassung, von Besonnenheit, von Gegenwart und Wachen des Geistes ist... Den edelsten Nabrungsstoff nun und in der edelsten Form, die goldenen Äpfel in silbernen Schalen, enthalten die Werke der Alten, und unvergleichbar mehr als jede anderen Werke irgendeiner Zeit und Nation.
\end{abstract}

As the true spirit ("Geist') of the texts can only be experienced in the original language (he observes that translations can communicate the content but not the form of the texts, and

\footnotetext{
${ }^{26}$ Apel in: Landfester (1999), 114.

27 Waquet (2001), 9.

28 Quotation from Waquet (2001), 26-7. See also Fritsch (1976), 117-8 and Apel in: Landfester (1999), 114119.

${ }^{29}$ Landfester in: Landfester (1999), 919-922.
} 
compares them to lifeless artificial roses), pupils must learn the ancient languages. The "mechanische[s] Moment der Spracherlernung" is a valuable educational process, as it involves the study of grammar, which is "der Anfang der logischen Bildung". Conscious grammatical learning of a language is a valuable exercise because it forces the pupil to take the necessary words and apply the relevant rules: "Somit...findet ein beständiges Subsumieren des Besonderen unter das Allgemeine und Besonderung des Allgemeinen statt, als worin ja die Form der Vernünfttätigkeit besteht. ${ }^{, 30}$ Formale Bildung is a term often used to describe this training of thought processes. Throughout the $19^{\text {th }}$ century, formale Bildung and moralische Bildung were the dominant principles of education in the Humanist Gymnasien. The failure of the 1848 revolutions and the reactionary politics which dominated in the aftermath contributed to the primacy of formale Bildung rather than the development of individualism which had been the goal of Humboldt's Neubumanismus. ${ }^{31}$

Kaiser Wilhelm II spoke at the Prussian school conference of 1890, expressing his will that the Gymnasium become truly national.

Wir müssen als Grundlage für das Gymnasium das Deutsche nehmen; wir sollen nationale junge Deutsche erviehen und nicht junge Griechen und Römer... Der deutsche Aufsatz. muß der Mittelpunkt sein, um den sich alles drebt. ${ }^{32}$

The trans-national outlook of Greek and Roman studies became politically incorrect in the context of $19^{\text {th }}$ century nationalism. The Roman empire was seen as "antinational" because of its conquest of 'free' peoples, while Arminius gained in stature as a representative of national unity and Germanic freedom. The Hermannsdenkmal, completed in 1875, became an important focus of national identity. The foundation of the German Reich in 1871 led to the construction of a historical model which presented the Reich's foundation as the natural conclusion of a process that had begun with Germanic resistance to Roman occupation. Thus the Germani provided a nationalist reference from ancient history and continued to be part of the attempts to satisfy demands for a "nationales" or "deutsches Gymnasium" until the end of World War II. ${ }^{33}$

\footnotetext{
30 Excerpts from Hegel's speech are printed in Reble, A. ed. Zur Geschichte der Höheren Schule, vol. 2, Bad Heilbronn, 1975 15-24, and reproduced in Fritsch (1976), 118-9.

${ }^{31}$ Landfester (1988), 19-20. Apel, Bittner (1994), 1.

${ }^{32}$ Speech printed in 'Verhandlungen über Fragen des höheren Unterrichts, Berlin, 4. bis 17. Dezember 1890', Deutsche Schulkonferenzien, vol. 1, Berlin, 1891 (reprinted, Glashütten, 1972), cited by Landfester (1988), 149150.

${ }^{33}$ Landfester (1988), 141-143.
} 
One of the principles of New Humanism in schools was that the pupils should be introduced as early as possible to the ancient world, "um diese in der Zeit der empfänglichen Jugendblüte zu ibrer besseren Heimat zu machen". ${ }^{34}$ Friedrich Jacobs and Friedrich Gedike were proponents of the Lesebuchmethode, whereby pupils should be introduced to coherent, meaningful texts from the beginning of their study and, where possible, to original ancient texts - though the early passages in the Lesebücher, due to the lack of ancient texts suitable for beginners, were compositions based on or adapted from ancient works. There was an emphasis on subject matter, rather than on the grammatical content of the passages. ${ }^{35}$

Despite the attention paid by some educationists and textbook authors to the subject matter and interpretation of texts, Latin teaching in the early $19^{\text {th }}$ century was more likely to be dominated by the use of a grammar and an Übungsbuch. The grammar was the guiding thread of lessons while the Übungsbuch provided examples for illustrating the grammatical points learnt. ${ }^{36}$ From the 1820s and 1830s the grammar-centred Übungsbuchmethode ${ }^{37}$ gained supremacy following criticism that the Lesebuchmethode produced unsatisfactory results. ${ }^{38}$ The Übungsbücher consisted largely, and sometimes exclusively, of individual sentences composed in order to demonstrate particular features of grammar and syntax. The emphasis was placed not on the provision of texts with stimulating and meaningful content, but on providing sentences that would allow pupils to practise grammar in a methodical fashion.

Throughout the $19^{\text {th }}$ century, university entrance could be gained only through the Gymnasium, where Latin and Greek were compulsory. ${ }^{39}$ The narrowly grammatical methodology of the late $19^{\text {th }}$ century reflected not only the importance of formale Bildung but also the practical requirements of Abitur candidates. It was mastery of Latin vocabulary and grammar that was essential for passing the Abitur exams. ${ }^{40}$ The dominance of the grammarcentred method and comparative neglect of subject matter in textbooks was to continue, despite various educational reforms and changes in pedagogical theory, until the 1970s. Even when pupils progressed to the reading of ancient authors, the continuing grammatical

\footnotetext{
${ }^{34}$ Jacobs, F. quoted by Lattmann, J., Geschichte der Methodik des Lateinischen Elementarunterrichts seit der Reformation. Eine specialistische Ergänzung zur Geschichte der Pädagogik, Göttingen, 1896, 263, in Fritsch (1976), 119. It is notable that Jacobs' point of view has nothing to do with a German Heimat projected onto the ancient world (see the discussions of the Ostermann textbooks below, as well as chapters 2 and 3, for projection of Deutschtum onto the ancient world).

35 Fritsch (1976), 122.

36 Müller (1975), 29.

37 As named by Lattmann (1896), 259, in Fritsch (1976), 120.

${ }^{38}$ Fritsch (1976), 128; Müller (1975), 29.

39 Müller (1975), 7. The decree of Wilhelm II on 26 November 1900 allowed the Oberrealschule and Realgymnasium to grant university entrance. Apel, Bittner (1994), ix.

${ }^{40}$ Müller (1975), 7.
} 
focus often resulted in the neglect of content and interpretation. The content of Übungsbücher and chrestomathies (selections of ancient texts, often adapted, for pupils in Quarta reading ancient authors for the first time) consisted largely of war narratives. The overall impression that many pupils must have taken away from their Latin lessons is likely to have been much like that described by Carl Hirzel:

So viel mir aus meinen eigenen Schuljahren im Gedächtnis geblieben ist, so trat damals der Inhalt des Übersetzten meist in den Hintergrund. Ich kann mich deshalb weder eines besonderen Woblgefallens, das ich an den Kriegsgeschichten der Römer gehabt hätte, erinnern, noch auch besonderen Missfallens... ob Titus Manlius Recht gehabt habe, seinen Sohn töten zu lassen, quod is extra ordinem in hostem pugnasset... darüber nachzudenken füblte ich mich nie aufgefordert; aber das weiß ich noch recht gut, dass in dem livianischen Stück, das die Hinrichtung jenes Manlius erzählt und in unserer Chrestomatbie sich vorfand, das lange Wort quandoquidem mir besonders interessant war, dass mehrere Sätze schwer zu übersetzen, die Ausdrücke, die der Lehrer gab, schwer zu behalten waren. ${ }^{41}$

Germania was such an important school text in the late $19^{\text {th }}$ century that Friedrich-August Eckstein's standard work on Latin and Greek teaching (1887) states that Germania appears in all lesson plans and asserts: "Das vaterländische Interesse macht es wünschenswert, daß kein deutscher Jüngling das Gymnasium verlasse, obne die Bekanntschaft mit dieser Schrift gemacht zu baben." ${ }^{42}$ National sentiment is the important motivation for attributing such importance to what Eckstein calls "ein Werk... für das wir Deutsche dem großen Historiker nicht dankbar genug sein können." ${ }^{43}$ Eckstein cites the national enthusiasm of a number of recent authorities, including Frick, who stated, "Die Germania jedem Schüler in die Hand zu geben hat das Gymnasium eine beilige Pflicht." ${ }^{44}$ Eckstein also recommends an interpretation according to which Tacitus recognises, "wahrhaft divinatorisch", in the Germanic Volk "[die] weltgeschichtliche Aufgabe..., das römische Kaiserreich zu vernichten und eine neue Zeit herbeizuführen." ${ }^{45}$ Eckstein's recommendations are a clear example of the influence of nationalist Germanenideologie on the interpretation of Tacitus' Germania in schools.

${ }^{41}$ Hirzel, C., Die Classiker in den niederen Gelehrtenschulen (Zur würdigung der Schrift von Dr. Eyth), Stuttgart, 1838, 15. Hirzel's publication was, as the title suggests, a reply to a speech published by Eduard Eyth, who had expressed concern that the overwhelmingly bellicose content of chrestomathies must have a negative effect on pupils. Eyth, E., Classiker und Bibel in den niederen Gelehrtenschulen, Basel, 1838. Cited by Müller (1975), 45.

42 Eckstein (1887), 241.

${ }^{43}$ Eckstein (1887), 240.

${ }^{44}$ Eckstein (1887), 241, n. 1.

${ }^{45}$ Eckstein (1887), 241. 
Christian Ostermann's Lateinisches Übungsbuch first appeared in $1860 .{ }^{46}$ It was re-issued and re-edited many times and was one of the most widely-used textbooks for pupils' first years of Latin in north and central Germany until the "preußische Richtlinien" of 1925. It represented the grammatistische Methode at its peak. ${ }^{47}$ Friedrich Hoffmann wrote in 1921, "Am Ostermann sind zwei Geschlechter von Lateinlehrern groß geworden." 48 The eighth edition of Christian Ostermann's Lateinisches Übungsbuch for Sexta from 1872 consists almost entirely of single, unconnected sentences either in Latin, for translation into German, or in German, for translation into Latin. There are more examples for translation into Latin than from Latin, which Ostermann justifies, indeed advertises, in his foreword, saying that translation from German into Latin was the best way to train pupils in the correct use of grammatical forms (Lat. Üb. Ost., iv: foreword to first edition, March 1860). Ostermann identifies the main learning goal of Sexta as "Fertigkeit in der Bildung der regelmäßigen Nominalund Verbalformen". He also aims to provide "Sicherbeit in der Anwendung der Casus in ibrer Uebereinstimmung mit dem Deutschen" (Lat. Üb. Ost., iii). The focus, therefore, is entirely linguistic. Linguistic instruction, furthermore, is centered on the word and its inflections (not on the sentence), and the use of noun cases insofar as they are comparable with the use of cases in German.

Groups of unconnected sentences are arranged like paragraphs of between 12 and 25 lines. The sentences tend to increase in length and complexity throughout the book. The sentences in each 'paragraph' focus on practising a particular point (or particular points) of grammar or syntax, and the vocabulary used in each reflects the words in the Vocabularium published by Ostermann along with the book of sentences. At the end of the book are some short fables and stories taken largely from myth and history (the content will be examined below).

Ostermann describes the sentences as "meist concreten Inhalts" and "so viel als möglich der Geschichte entlehnt" (Lat. Üb. Ost., iii). Although the Germani are mentioned mostly in individual statements scattered throughout the book, a uniform Germanenbild is evident. ${ }^{49}$ Germani, Germania, Germans or Germany are mentioned every two pages on average, though rather more frequently early on in the book than later. The use of the Germani as a topic in the early stages of a Latin textbook and their appearance more frequently in books for Sexta than those for later classes continues in traditional Übungsbücher until 1945 and in

\footnotetext{
46 It is hereafter referred to as 'Ostermann' or 'Lat. Üb. Ost.'.

${ }^{47}$ Lattmann (1896), 356, in Müller, 25. Fritsch (1976), 133.

${ }^{48}$ Hoffmann (1921), 27, in Fritsch (1976), 133.

49 There is a passage about Arminius among the stories at the end of the book.
} 
some cases after that. There is interchangeable usage of the terms 'alte Deutsche' and 'Germanen', 'Deutschland' and 'Germania' throughout. For example, in one sentence we find "Ein gesunder Sinn war in dem alten Volksstamm der Germanen" (Lat. Üb. Ost., 13), and on the next page, "Die Treue der alten Deutschen lobt Tacitus, ein berübmter Schriftsteller der Römer" (Lat. $\ddot{U}$ b. Ost., 14). Evidently the Germani are intended to be seen as ancient Germans and their comparatively frequent appearance early in the textbook reflects their role as points of identification for pupils. The ancient world is thus inhabited not only by Romans and Greeks, but also, according to the textbook, by Germans. ${ }^{50}$

The Germanenbild that develops is simplistic and is almost entirely made up of well-worn clichés. Many sentences are modified (usually simplified) versions of statements from Tacitus' Germania: “Die Körper der alten Deutschen waren sebr groß; sie waren größer als unsere Körper” (Lat. Üb. Ost., 31), “apud veteres Germanos boni mores plus valebant (vermögen), quam apud alios populos bonae leges" (Lat. Üb. Ost., 55). Stripped of their original context, the sentences, in so far as attention is to be paid to their content, are presented as if they were nuggets of fact. The good sense and loyalty of these Lebrbuchgermanen are introduced early on, along with their "bellica gloria”, their being “asperi et bellicosi" (Lat. Üb. Ost., 7) and later their love for "Gebrauch der Waffen" and their surpassing all other nations "fide et probitate" (Lat. Üb. Ost., 23).

In rare instances, current events and recent history crop up among the sentences, and the blurred distinction between Germany and Germania, Germans and Germani allows modern events into the midst of sentences that describe the ancient world. In fact, the word Germanien is used nowhere in the German examples, the word Deutschland being preferred. The Deutsche appear as latter-day Germanen. Perhaps the clearest example is a comparatively long practice sentence near the end of the book: "Die Deutschen haben beschlossen (festgesetzt) dem Arminius, welcher im Jahre 9 n. Chr. die Deutschen von der Herrschaft der Römer befreit hat, ein Standbild zu errichten" (Lat. Üb. Ost. 66). Presumably the pupil is expected to translate both occurrences of 'die Deutschen' as 'Germani.

The focus on "Grammatik und Krieg" that long dominated Latin classes is evident in Ostermann. ${ }^{51}$ Because of the exclusive use of the word 'Deutschland', it is hard to know

\footnotetext{
50 The sentence, "Die alten Deutschen waren uns sehr unähnlich" appears on page 50 but this statement of the obvious does not discount the general assumption that the Germani were in essence deutsch.

51 The phrase "Grammatike und Krieg" is widely used by Andreas Fritsch - see especially Fritsch (1991), 4 - and Stefan Kipf.
} 
whether the following sentences are supposed to refer to modern Germany or to Germania.

Die Siege Deutschlands bereiten dem V aterlande Ruhm und Freude (Lat. Üb. Ost., 3).

Der glänzende Sieg der Deutschen bereitet unserer Nachkommenschaft einen sicheren und langen Frieden (Lat. Üb. Ost., 27). ${ }^{52}$

Predictably, the Germanic military leaders Arminius and Ariovistus feature several times each and Arminius is the subject of one of the passages at the end of the book, of which Ostermann writes, "Den Schluß des Buches bilden einige kleine Eräählungen und Fabeln in der leichtesten Form, da das Bedürfnis einer zusammenbängenden Lektüre auch für diese Stufe vielfach ausgesprochen ist' (Lat. Üb. Ost., iv, foreword to first edition, March 1860). Apart from the fables, the passages are mythological or historical in content. Tales from early Roman history are prominent, including Romulus, Sabinorum virgines rapiuntur, Tarquinius Superbus, Horatius Cocles, Mucius Scaevola and Pyrrbus. The only story from the age of imperial Rome is Arminius. The particular focus on the early Roman Republic and lack of emphasis on the Empire was a feature of most school textbooks until the last few decades of the $20^{\text {th }}$ century. ${ }^{53}$

As is to be expected, the passages present considerably simplified versions of the stories they tell. The story of Arminius is a pale and highly selective version of the events as recounted by Roman historians. All that we have is a brief narration of how Varus treated the Germani "pessimo modo", how the Germani decided to free themselves from Roman rule and how Arminius attacked the Romans when they were impeded by storms and mud in Teutoburg Forest. Varus then falls on his sword and Augustus, when he hears of the news, cries, "Vare, Vare, redde... mihi meas legiones?" There is no mention of Arminius' Roman training or of his using an alliance to trick Varus. Arminius is simply a heroic commander who displays prudentia and fortitudo.

The passages about figures and events from early Roman history are similarly simplistic. What little comment they do include promotes a pro-Roman interpretation of events and

\footnotetext{
52 It is tempting to see a reference to Germany's recent success in the Franco-Prussian war. The question of where the boundaries of Germany should lie seems to appear in some examples such as, "Der Rhein, ein breiter Fluß Deutschlands, hat schöne Ufer" (8). The description of the Rhine as a German river crops up frequently amongst the first sentences of textbooks.

53 After the foundation of the Reich in 1871, nationalism contributed to the portrayal of imperial Romans as degenerate compared with the virtue of the Germani (Landfester (1988), 142-143).
} 
one that is in line with conservative Roman republican values. Romulus' murdering Remus is mentioned perfunctorily and followed by praise of his strong kingship: "Postquam Romulus fratrem interfecit, nova urbs Roma appellata est. Ipse autem Romulus erat rex fortissimus. Itaque multa bella suscepit et multos populos, qui circa... Romam habitabant, regno suo adjecit." Fortitudo is the virtue around which most of the passages are built. Romulus (as above), Horatius Cocles ("Ita unius viri fortitudine Roma servata est"), Mucius Scaevola ("vir fortissimus"), Pyrrhus ("vir fortissimus et belli peritissimus") and Arminius all owe their greatness and historical importance to fortitudo.

Many textbooks, it must be noted, used the same selection of words in the earliest lessons, due to the preference for beginning with first declension nouns and first conjugation verbs in various inflected forms. There may be lists of countries with first-declension names, and feminine nouns such as patria, gloria, regina are very common. In order to introduce males early on, it is found necessary for poetae, agricolae and nautae to fill the early lessons. ${ }^{54}$

In 1892 Hermann Johannes Müller published a new, re-worked edition of Ostermann's Übungsbuch and stated in the foreword his approach to the much-revised textbook. Ostermann's revisions, he said, had never really solved some of the important problems with the book and had simply made each new edition difficult to use alongside its predecessors. He goes on to say,

\begin{abstract}
Die preußischen Lehrpläne vom 6. Jan. 1892, durch die eine Umgestaltung der Ostermannschen Lebrbücher notwendig geworden ist, haben mir eine erwünschte Gelegenheit gegeben, mit den vielfach ganz. unbrauchbaren Sätze der früberen Ausgabe schonungslos aufzuräumen und dem Ganzen ein neues und zeitgemäßes Gewand anzulegen. Die Sätre batten, wie bekannt, teils einen ungeeigneten Inbalt, teils waren sie unlogisch gefaßt, teils verstießen sie im Ausdrucke gegen den Geist der Sprache: in allen diesen Beziebungen ist Wandel geschaffen worden (Lat. Üb. Ost.-M. (1896), v, foreword to first edition, March 1892).
\end{abstract}

\footnotetext{
${ }^{54}$ Bruno Snell's Neun Tage Latein begins with an affectionate reminiscence of the strange world into which the earliest Lateinbuch sentences introduced him as a schoolboy. Although he was not a particularly enthusiastic pupil, he says, "Immerbin war es doch schon eine kleine Verzauberung, wenn die erste Lateinstunde mit dem Satz anfing: "Die Tochter des Landmanns schmückt den Altar." Welch ein Land, welch eine Zeit, da die Königin sich an Rosen ergötzte und die Einwohner der Insel ein Mabl bereiteten" (Snell (1968), 3). Snell's amused recollections of an imaginative engagement with a world composed largely of first-declension nouns is, however, to be seen against the complete lack of engagement with the subject matter reported by many students. See for example Waquet (2001), 39, and Hirzel (above).
} 
Müller states that almost no line has been taken over unchanged from the old Ostermann to the 'neue Ausgabe' and that almost all the stories and fables (the 'rusammenhängende Stücke') have had to be tossed out. The material has been simplified to fit in with the reduction in the hours spent on Latin per week. Deponent verbs and most irregular verbs have been delayed till Quinta and the amount of vocabulary to be learnt has been reduced by about a fifth (Lat. Üb. Ost.-M. (1896), vi, foreword to first edition, March 1892).

The role of 'zusammenhängende Stücke' has been increased. At first Müller sticks to the principle that word-forms are best practised through single sentences. In the book for Sexta they do not make their appearance until the second quarter of the year, but in the second half of the year they come to the fore. In Quinta they come to predominate over the individual sentences (Lat. Üb. Ost.-M. (1896), vii-viii, foreword to first edition, March 1892).

Müller states that he wants to avoid presenting in his texts "ein ungewöhnliches Vielerlei... von dem man alles andere, nur nicht Gedankenkonzentration erwarten darf' (Lat. Üb. Ost.-M. (1896), viii, foreword to first edition, March 1892). The content of the textbook for Sexta is, he says, taken primarily from Greek and Roman legend. The first eleven passages, however, include introductions to the Greeks, the Romans, "Die Deutschen", the Persians, and later the Cimbri and Teutones. Greek and Roman poets, orators, military commanders and writers then have a passage each of their own, and the battles of Marathon, Salamis and Plataea are also described. The historical subjects that gain a mention in the remaining passages are grouped together: Alexander the Great, "Die Heldenthat des Arminius" and the battle of Thermopylae. War is the most prominent theme, with writers and orators in the background, and the battle in Teutoburg Forest is among the few great historical events to be mentioned.

Andreas Fritsch's comments on the first of the passages, Die Griechen, are rightly critical of the failure of the passage to live up to Müller's own decision to put texts ('zusammenhängende Stücke') in the place of single sentences. As Fritsch observes, this passage is not so much a coherent text as a series of individual sentences which have only apparently been drawn together to make a text. Furthermore, many of the sentences are "praktisch inhaltsleer", telling us, for example, that the inhabitants of Athens were the Athenians. ${ }^{55}$

${ }^{55}$ Fritsch (1976), 137. 
The passages do show an attempt to introduce pupils to the ancient world, Greek as well as Roman, and although they are necessarily simple and are a "sehr gemischte Zusammenstellung", 56 which could prove confusing to a pupil, they nevertheless create some strong impressions due to their stylised, often stereotypical, portrayal of the ancient world. Each of the peoples described is assigned certain distinguishing characteristics. These are conventional stereotypes. Greece is peopled by cultivated Athenians, warlike Spartans, steadfast Thebans and wealthy Corinthians, who wage war with arrogant Persians.

Athenienses litteras et sapientiam amabant, bella populum Lacedaemoniorum delectabant, Thebani constantia clari erant, Corinthii magnas divitias habebant. Graecis bella erant cum Persis; causa bellorum fuit superbia Persarum (Lat. Üb. Ost.-M., 10).

The Romans, meanwhile, are "semper bellicosi", but their expansionism is presented more positively than that of the Persians.

Romani non modo cum...populis Italiae, sed etiam cum populis aliarum terrarum bella gerebant,...velut...cum Carthaginiensibus, Graecis, Germanis. Multi Romani erant duces egregii et multis victoriis populo Romano et magnam gloriam et magnam potentiam parabant. Antiqui scriptores amorem patriae et constantiam Romanorum laudant. Castra et proelia iuvenes Romanos delectabant (Lat. Üb. Ost.-M., 13).

Persae bellicosi erant et ceteras gentes Asiae audacia superabant. Persae multarum gentium victores fuerunt et imperium Persarum magnum erat... Graeci copias Persarum multis proeliis... superabant, et fuga hostium foeda erat... Postremo Persae sub imperio Alexandri erant, et incolae urbium, agricolae, milites, mercatores iustitiam novi regis laudabant (Lat. Üb. Ost.-M., 17).

The Germani, meanwhile, are just as much of a caricature as they were in the earlier editions of Ostermann. The only event in Germanic history that gains a mention is Arminius' victory over Varus, described here as his "Heldenthat". He is the liberator of Germania (following Tacitus' description, “liberator haud dubie Germaniae” at Ann. 2.88). The story about Arminius is more detailed and less simplistic than that of the older Ostermann, but still noticeably tendentious in its positive portrayal of the Germanic victory. This time it is, however, acknowledged that Arminius had served in the Roman army, that he was "non modo artis bellicae et omnino... rei militaris, sed etiam dolorum insidiarumque peritus" (Lat. Üb. Ost.-

${ }^{56}$ Lattmann (1896), 375, in Fritsch (1976), 138. 
M., 53). The passage begins with Caesar's campaigns followed by those of Drusus and Tiberius, then describes Varus' excessive demands for tribute from the Germani, who "neque... aurum neque... argentum habebant." Only the victorious episodes of Arminius' life gain a mention. Nothing is said about the later, less glorious, years of Arminius' life that culminated in his death "dolo propinquorum" (Tac. Ann. 2.88), as the Arminiusbild presented in the Ostermann books is very much a heroic one, characterised by glory and victory. Since the war against Napoleon, Arminius' victory had often been appropriated to symbolise "Befreiung von Fremdherrschaft und... [die] Selbstbehauptung naturhafter, kollektiver Kräfte gegen rational organisierte Macht' ${ }^{57}$ Arminius' victory over Varus in 9 AD was frequently portrayed as an expression of the desire of the Germanic Volk to be free. In the Ostermann textbooks and later textbooks that present a traditional Germanenbild, the battle in Teutoburg Forest is generally presented in a way that reflects the notion of a "Volkskampp". 58

Despite the primacy of grammar over subject matter in Ostermann and Ostermann-Müller, these widely-used Übungsbücher create some strong impressions about the ancient world through the stylised and highly selective subject matter of individual sentences and basic passages. The Germani are in most cases described in simplified and de-contextualised versions of statements by Tacitus, while the battle in Teutoburg Forest is described in a way reminiscent of Velleius' account, influenced by other ancient sources and by the modern post-Napoleonic Hermann myths. War is the principal topic of sentences and passages, and the Germani are often portrayed as warriors and opponents of the Romans. Tacitus' Germania is a difficult text to interpret, requiring at the very least an awareness of conventions and commonplaces of the ancient ethnographic tradition, and the effects of interpretatio Romana. Against the background of enthusiasm for Germani as ancient Deutsche, the presentation of versions of Tacitus' ethnographic statements out of context and without comment served to transmit and perpetuate an impression of the noble barbarian that was a popular way of viewing the Germani in the $19^{\text {th }}$ and early $20^{\text {th }}$ centuries.

\footnotetext{
57 Timpe $(2006=1999), 446$. Timpe points out that the fight against French hegemony, which was principally a war between states, was celebrated as a kind of Volkserhebung. Arminius' victory was used to convey a similar notion.

58 The word Volkskampf is used by Timpe (2006=1973), 229. Timpe suggests that the rebellion led by Arminius may have been primarily an auxiliaries' revolt, rather than a people's uprising.
} 
The Richtlinien der böheren Schulen Preußens of 1925 show the effects of an educational reform movement that had led to a school reform in 1924. The Prussian reforms set the standard for the whole Republic and the Gymnasium, as a school for the future elite, still had great prestige: “...in der damaligen Zeit war das Gesicht des Gymnasiums ausschlaggebend auch für die Gestaltung der anderen Schularten, und nicht zuletzt der Universität. Die Tatsache, daß die Weimarer Republik sich ein deutschnationales Gymnasium schuf, bestimmte das bildungspolitische Klima."

Three of the most important methodological principles for language teaching set out in the 1925 Richtlinien were as follows: firstly, "Aller Sprachunterricht muß durchaus von dem Anschaunngs- und Interessenkreis des Schülers ausgehen." Secondly, "Die Methode alles grammatischen Unterrichts ist die induktive. Aus der Fülle der sprachlichen Erscheinungen ist das Prinzip berauszuarbeiten." Thirdly, "Aller Sprachunterricht muß sich auf den schon früher erworbenen grammatischen Kenntnissen aufbauen und an schon vorhandenes sprachliches Wissen - aus der Mutteroder einer schon bekannten Fremdsprache - anknüpfen; die Grundlagen des Verständnisses spracblicher Erscheinungen überhaupt müssen an der Muttersprache selbst gewonnen werden."

With respect to subject matter, an important influence was the Deutschkunde or Kulturkunde movement, an attempt to re-build a confident national identity after the capitulation of Germany in World War I and the emergence of conflict between increasingly irreconcilable political movements. ${ }^{61}$ The Kulturkunde movement placed German culture at the centre of education. German, Geography, History and Religion became the most important subjects. Hans Richert, who was instumental in the school reform of 1925 published Die deutsche Bildungseinheit und die böhere Schule in 1920 and described how learning about foreign cultures must be justified by drawing attention to "die Verbindungsfäden von der fremden Kultur zum deutschen Leben." ${ }^{2}$

Another important concern of education under the Weimar Republic, and an attempt to raise young people who accepted democracy and republicanism, was Staatsbürgerkunde. Article 148 of the Weimar constitution stated the following: "In allen Scbulen ist sittliche Bildung, staatsbürgerliche Gesinnung, persönliche und berufliche Tüchtigkeit im Geiste des deutschen

\footnotetext{
${ }^{59}$ Becker, Kluchert (1993), 370.

${ }^{60}$ Richtlinien für höhere Schulen Preußens, Beilage zum Zentralblatt für die gesamte Unterrichtsverwaltung, 1925, 8, p. 23. See Fritsch (1976), 143.

${ }^{61} \operatorname{Kipf}(1999), 181-182$.

62 Richert (1920),139 cited by Kipf (1999),183-184.
} 
Volkstums und der Völkerversöbnung zu erstreben... Staatsbürgerkunde und Arbeitsunterricht sind Lehrfächer der Schulen." ${ }^{63}$ The actual values involved were ill-defined and it was generally accepted by around 1930 that schools were failing to produce staatsbürgerliche Gesinnung in their pupils. ${ }^{64}$ I have chosen not to discuss Staatsbürgerkunde in detail as Kulturkunde is more relevant to the portrayal of the Germani in textbooks. The Germani are far less important than the Romans and Athenians in providing a model for a state, but they are very important as representatives of a Deutschtum that is projected back onto the ancient world. History was the subject which carried the greatest responsibility for teaching Staatsbürgerkunde. ${ }^{65}$ Kulturkunde impinged on Staatsbürgerkunde in so far as it produced a strongly positive portrayal of the Germani influenced by nationalist political sentiments allied with the authoritarian paternalism and militarism which pervaded the portrayal of the ancient world in textbooks. The Germani were, therefore, presented in a way which had little or nothing to do with republican values, democracy or Völkerversöhnung.

Tacitus' writings on the Germani were involved in an attempt to bring Kulturkunde into the upper classes of the Gymnasium where Latin texts were selected for reading. Chapters 1-27 of Germania were to be read in Obersekunda in an edition that included excerpts from chapters 28-54 and selections from other ancient sources on the Germani. In Unterprima and Oberprima the prescribed reading included a large range of texts demonstrating the importance of Rome in world history as well as the topic of Romano-Germanic encounters centred on Tacitus' Annals with selections from the Histories, from Velleius Paterculus, Suetonius, Dio Cassius (in translation) and others. ${ }^{66}$

The Latin course Ludus Latinus was developed 'in the spirit of the reform of 1924/1925. ${ }^{67}$ First released in 1926, it was re-printed, re-released and, at times, extensively re-worked up to the 1970s. The Übungsstücke are divided into Latin texts for translation and German texts for translation. The foreword to the first edition makes it clear that the authors were guided

${ }^{63}$ Die Reichsschulk:onferen\%. Ibre Vorgeschichte und Vorbereitung und ihre Verhandlungen. Amtlicher Bericht, erstattet vom Reichsministerium des Innern, Leipzig, 1921, 755 as cited by Geiger (1993), 2.

${ }^{64}$ See the discussion of Geiger (1993),1-20

65 The Germani also played a role in bringing Deutschlandkunde and nationalism to history classes: "Man wollte Alemannen und Franken als den Römern ebenbürtige germanische Völker darstellen. Besonders deutlich treten die zeitgeschichtlichen Beqüge des Jahres 1925 im Lehrplan hervor, wenn... von "Deutschlands Westgrenze, Beginn des Kampfes um den Rhein" die Rede war" (Joos (1997), 34).

66 Apel, Bittner (1994), 177-178. Records of inspected lessons from the Rhine province in the years 19251933 report digression from the prescriptions of the Richtlinien in $40.6 \%$ of lessons, and there is only one recorded instance of Germania being read. We cannot tell from the fragmentary evidence how often Germania was actually read, but it seems nationalistic intentions expressed through the Kulturkunde programme were often not carried out as the authorities intended, despite the fact that, officially, Germania was allotted greater importance in the later Weimar Republic than it had been before and during World War I (Apel, Bittner (1994), 187, 194-197).

${ }^{67}$ Ludus Latinus, Lese- und Übungsbuch für Sexta, first edition (1926), v-vi. 
by the methodological principles of the 1924/1925 reform and Kulturkunde-based justifications for Latin teaching.

Das Gebotene liegt ganz im Umkreis der Anschaunngen und Liebhabereien eines zehnjährigen Jungen. Die beigegebenen Skizzen werden es dem Schüler erleichtern, den Inbalt der Sätze in sich lebendig werden zu lassen. Dazu treten Stücke, die Römern, den alten Deutschen und den Beziebungen beider Völker gewidmet sind, und ein paar Stücke mit griechischem Sagenstoff (LL ${ }^{1} I$, vii).

There is a new emphasis on the Germani and on Romano-Germanic encounters. The Germanic material, which appears with special frequency in the early stages of the books and more frequently in the volumes for Sexta and Quinta than in that for Quarta, is regarded as deutsch and thus satisfies the requirements of Kuturkunde and of comparative familiarity for young pupils.

Ernst Habenstein wrote in 1963 about the impressions the new series made on him as a teacher when it first appeared.

Das Buch begann, was den Inhalt der Stücke betrifft, mit allgemeinen Lebensverbältnissen, deren Erscheinungsbilder sich zwar in 2000 Jahren gewandelt haben (villa - Haus?, mensa - Tisch?, tectum - Dach?), zu denen aber doch ein unmittelbarer Zugang möglich war... [E]rst nach einigen Wochen mit der Einführung der Imperfektformen pugnabant, bellabant begann sich die fremde, ferne $W$ elt aufzutun, erschienen die Romani. Die neuen Bücher hatten - ein Novum in der Lateinbuchgeschichte seit der Zeit des 'Orbis Pictus' Illustrationen im Text und ganze Bildseiten. ${ }^{68}$

In Ludus Latinus, the earliest passages revolve to a large extent around everyday German life in a manner reminiscent of children's storybooks or fairytale collections. When the texts describe the ancient world, the topic of Germani and their relations with the Romans is especially prominent. Just as we have seen in the Ostermann textbooks, the word "Deutsche" is freely used to translate "German", and the boundaries between Germania antiqua and Germania recentior are considerably blurred. Along with the ancient Germanic topics that occur frequently throughout Ludus Latinus, there are two passages with recognisably German topics: Rotkäppphen and Die Leutseligkeit Friedrichs des Großen. In many respects the attempt to bring Latin into everyday and specifically German contexts was

${ }^{68}$ Habenstein (1963), 5. 
strengthened after the book's first release, as we shall see in the discussion of the 1932 edition of Ludus Latinus I.

At the beginning of the section of Latin for translation are eight separate two-word sentences illustrating verbs of the first conjugation in the third person singular and plural of the present tense. The first stories are as follows: Das Mittagessen. Der Schiffer. Großmutters Hof und Haus. Die Webstube. Der Jäger. Der Frosch. Der Hirsch. Auf dem Hofe. Ferien. So far we remain in a world familiar to a ten year-old child from experience or children's stories. Accompanying the sentences and passages are line drawings reminiscent of Wilhelm Busch comics - the grandmother could easily be the familiar story book figure of Witwe Bolte. ${ }^{69}$

The next three passages finally introduce the pupil to the ancient world. The subject matter, Der Rhein, Die Römer and Die Lebensweise der Germanen, gives Germania and Germany more attention than Rome. Der Rhein presents the river as a source of pride for the Germani, whose poets sing its praises: "Germani Rhenum amant et laudant. Saepe poetae Germanorum de Rheno narrant et fluvium celebrant" $\left(L L^{1} I, 6\right)$. Poets who praise the fatherland are a common feature of Germanophilic Lateinbuch sentences, probably due to Tacitus' reference to Germanic songs of myth and history in Germania (2.3) and the mistaken reading "barditum" (Germ. 3.1, sometimes misinterpreted as bardic song), neither of which, however, are specifically patriotic. $^{70}$ The synchronic nature of so many of the references to ancient and modern Germania and Deutschland suggests resonances with the $19^{\text {th }}$ century notion of Germany as the land of Dichter und Denker. The dominant geographical feature of Germania is the forest, full of wild beasts. Here the Wald is described in its ancient, wild state (Urwald): "In silvis Germaniae, discipuli, olim cervi et lupi et ursi habitabant" (LL $\left.{ }^{1} I, 6\right)$. The forest is also the site of animal sacrifices to the Germanic gods carried out by the inhabitants who live as hunters (see appendix, figure 2). The period of rapid urbanisation from the mid-19 $9^{\text {th }}$ century up to the First World War had produced in some quarters "images of alienation, powerlessness, unceasing change, anonymity, and rationalisation". "The Humanist Gymnasien, with

\footnotetext{
${ }^{69} \operatorname{Kipf}(2006), 69$.

70 In most manuscripts, Germ. 3.1 reads: "sunt illis haec quoque carmina, quorum relatu, quem barditum vocant, accendunt animos, futuraeque pugnae fortunam ipso cantu augurantur...”. Some manuscripts read baritum for barditum. barditum, however, is likely to be a corruption, as its reminiscence of the Gaulish bards is out of context. baritum, meanwhile, is usually justified by reference to barritum, which, however, seems unlikely as the word first occurs in Ammianus and Vegetius and describes the trumpeting of elephants. There is no general agreement on the passage. Koestermann (1964) ad loc. accepts barditum, Winterbottom (1975) ad loc. puts barritum, while Lund (1988), 118-119 places the crux desperationis around baritum. The influence, outside academia, of the notion of Germanic bards in battle can be seen in Heinrich von Kleist's play Die Hermannsschlacht, in which a bardic choir sings before the battle in Teutoburg Forest (Act 5, Scene 14). It should also be remembered that as poeta is a first-declension noun, it fits with the method of introducing firstdeclension nouns before other declensions.

${ }^{71}$ Breuilly (2003), 218.
} 
their conservative and sometimes reactionary tendencies and reference to timeless Humanist values often idealised the ancient world, which could be seen as a refuge from Kulturpessimismus. The wildness of the ancient German forest provided an antithesis to modern urban materialism. ${ }^{72}$ Stefan Kipf has pointed out the continued use of stylised Lebrbuchlandleben in the early stages of textbooks of the 1950s and 1960s which were based on the methodology of the Weimar Republic. ${ }^{73}$

The Germani are described in numerous other passages: 7. Die Lebensweise der Germanen; 34. Die Germanen: Männer, Frauen und Sklaven; 40-42. Befreiung Deutschlands vom Römerjoch; 51. Die Germanen: Krieger, Priester, Freunde, Frauen; 52. Der Freiheitsdrang der Germanen; 58. Die Fürsten der Germanen und ibr Gefolge; 86. Stolze Unterhaltung eines Deutschen mit einem Römer. The range of stories on specifically Roman topics is as follows: 12. Die Römer; 16. Romulus; 20. Die römische Familie; 29,30. Römische Kriegszucht; 35. Das Römerreich; 37. Der römische Senat; 53. Der Kaiser Augustus; 54. Der römische Triumph; 57. Die römische Legionen; 66, 67. Wie behandelten die Römer ibre Toten? 74a. Die Gastmähler der Römer; 74b. Grabinschriften und Sprüche; 76. Blick auf Rom und Gang durch die Stadt; 85. Die Lagerwache.

Specifically Roman passages outweigh the passages on the Germani or those on RomanoGermanic encounters, but not greatly. As a result the pupils beginning Latin with Ludus Latinus could easily have been led to believe that Romano-Germanic relations were the single most important thread of Roman history. The theme of Romans at war is by far the most prominent one in the book - a continuation of the bellicose subject matter of $19^{\text {th }}$ century textbooks - and Ludus Latinus places especial emphasis on Rome's wars in Germania. The very first time the Romans are mentioned, it is as follows: "Romani bellum amabant. Arma et proelia et bella Romanos semper delectabant. Romani etiam cum Germanis bellabant" $\left(L L{ }^{1} I, 7\right)$. Most pupils would be preparing for a reading of Caesar's Gallic War at some point. The Gauls, however, are barely mentioned at all in Ludus Latinus, as the Germani provide greater national interest.

The passages about the Germani present a familiar picture of brave warriors, strict morality and simple life among the fields and forests. The battle in Teutoburg Forest features prominently, with three consecutive passages that closely resemble the examples we have

\footnotetext{
72 Since the late $19^{\text {th }}$ century many cultural movements had sprung out of "Kulturpessimismus" and "Zivilisationsmüdigkeit" which led to a desire for the primitive and the rejection of the progress, rationalism and industrialisation that were associated with modern cities. The Art Nouveau (Jugendstil) movement, the establishment of artists' colonies away from large cities (most notably the Künstlerkolonien in Worpsweder and Dachau) and the $W$ andervogel movement are representative of such trends (von See (1970), 63-64).

${ }^{73} \operatorname{Kipf}(2006)$, 69-70.
} 
seen from Ostermann-Müller. The first describes Varus' arrogance and greed (he is superbus and avarus) and his attempts to exact tribute from the Germani, who had 'neither gold nor silver', "ut populi Germaniae ira et odio flagrarent." Enter Arminius with his plan to free 'the fatherland' (patria). In the next passage are described Arminius' Roman military background and his trickery. The third describes the battle. The triumphant tenor of the passages is set by the title "Befreiung Deutschlands vom Römerjoch" and the blurring of Germania and Deutschland, Germani and Deutsche is again apparent in the concluding sentences: "Grato animo nunc statuam Arminii in saltu Teutoburgensi... collocatam spectamus. Arminius a Tacito "liberator Germaniae" apellatur. Germania a Romanis nunquam recuperata est." Presumably the idea is that "we" view the Hermannsdenkmal with a feeling of satisfaction at knowing that Arminius prevented Germania from becoming a Roman colony, identifying the freedom of Germania with the freedom of Germany $\left(L L^{1} I, 20-21\right)$.

In a German passage about Napoleon, entitled 1806 und 1813, 'Francogalli' is the recommended translation for 'Franzosen'." The recommended translation for "Die Engländer" in the text with that title is "Britanni", rather than, for example, Angli. An artificial 'classical' patina is superimposed on Latin descriptions of modern history in Ludus Latinus. The use of ancient terminology in inappropriate modern contexts goes hand in hand with an uncritical acceptance of ancient martial values. The Romans and the Germani love war. They look forward to battles and heap praise and glory upon the bold, derision upon the cowardly. The English are the subject of a text that says that, just as the ancient Phoenicians were "klüge Kaufleute und kühne Seefahrer, so baben die Engländer (Britanni) durch Klugheit und Kühnheit das Meer an sich gerissen... Und da sie klug und kühn und zäh waren, haben sie einen großen Teil der Welt erobert". 75 The characteristics of the English, though effective, are clearly in contrast with the Germanic virtues of simplicity, bravery, loyalty and incorruptibility. The comparison with the Phoenicians, moreover, aligns them with familiar negative Semitic or Jewish stereotypes. ${ }^{76}$ In a subject which claimed to give moral education, martial values are those most consistently championed, and against the background of language that blurs the distinction between ancient and modern, ancient warriors and empires are set up as the most admirable of models for the modern world.

In passage 33, "Wo ist Paul?" we find the Sextaner and Quintaner in the forest fighting a battle.

${ }^{74}$ Ludus Latinus I, 1926, V orabdruck aus der 2. Auflage, 3.

${ }^{75}$ Ludus Latinus I, 1926, Vorabdruck aus der 2. Auflage, 13.

76 The ethical antithesis of "Händler und Helden", which was the title of a polemical publication of 1915 by the sociologist and economist Werner Sombart, fitted the old model of Römer versus Germanen (von See (1970), 68-69). 
'Cum amicis in silva fui; ibi magna pugna inter sextanos et quintanos fuit. Ego sextanis praeeram, Carolus quintanis praeerat... Quintanis insidias paravimus et magna pugna adversarios superavimus. Quintanis animus deerat; ignavi erant.' 'Laudo Paule, quod ludis amicorum intereras; sed postulo, ut hora cenae adsis. Pulchrum est amicis adesse; non pulchrum est officio deesse' $\left(L L^{1} I, 17\right)$.

Passage 77, entitled "Schulausflug", also includes a battle scene, this time at the instigation of a schoolteacher.

Magister: Hic dies festus est, dicipuli; hoc die liberi estis laboribus. Contendemus in silvam atque ludis et pugnis delectabimur. Hi Germani, illi Romani erunt.

The Dux Romanorum (D.R.) and the Dux Germanorum (D.G.) then proceed to deploy their troops and make exhortatory speeches:

D.R.: Multitudine Germanorum non terreor. Nam pectora horum virorum et munimenta borum castrorum tam firma sunt, ut nibil timeam...

D.G.: Nunc hostes tenemus. Nemo perniciem evitabit. Uno impetu haec castra expugnabitis. Facilis nobis victoria! (Summa vi utrimque pugnatur.)

Magister: Satis est. Summa fortitudine pugnavistis. Huius diei memoriam retinebimus! Nunc corpora et animos cibo et potu recreate! $\left(L L^{1} I, 42 .\right)^{77}$

Just as the pupils are being educated into a Latin world at school, Ludus Latinus portrays them playing the role of little barbarians when they enter the forest (the defining geographical feature of Germania). ${ }^{78}$ The schoolboys at play in Ludus Latinus are warriorssometimes Germani, sometimes, in line with their Latin education, Romans.

The 1932 edition of Ludus Latinus has undergone revision throughout. Immediately noticeable is the colour picture facing the title page - the first colour picture in a German Latin textbook. ${ }^{79}$ The picture shows a German farmyard complete with half-timbered and

77 “Wo ist Paul?" appears again in Ludus Latinus I A, 1932. "Schulausflug” has, however, been removed.

78 Almost exactly the same sort of Schulausflug is described as taking place in 2007 (albeit with more historical content and less spoken Latin) at the archaeological park of Kalkriese, the possible site of the 'Varusschlacht'. "Als die Legionen im Nebel verschwanden"; FAZ 22/09/07; Reiseblatt 1, 3;. Playing soldiers is not an uncommon way of enlivening classics lessons in schools. As the teacher in the quoted passage states, such excursions tend to stay in the memory of the students (probably because the children can more easily slip into the role of barbarians than of bearers of civilisation).

${ }^{79}$ Habenstein (1963), 5. 
thatched buildings, a family in rural dress eating lunch and a village with a church nestled in the rolling hills in the background (see appendix, figure 3). Despite the absence of the Little Red Riding Hood and Frederick the Great stories, the emphasis on things German is still strong. Preceding the Latin pieces is a short text, Zur Vorbereitung. Zur Arbeit und Freude für die ersten Lateinstunden. It is in German sprinkled with familiar Latin nouns. The use of Latin terminology to describe many features of school life is supposed to give the pupil a sense of entering into a school world of which Latin is an integral part ("Da fübrt euch der ordinarius der sexta in die aula..."), though it was no longer as important as it had been. ${ }^{80}$

Since the first edition, the authors had reduced the required vocabulary by around 50 words and made sure that the texts used the prescribed vocab as exclusively as possible $\left(L L{ }^{8} I\right.$, iii). The essentials include a large amount of martial vocabulary from the earliest stages of the book. The practice sentences are as follows:

Germani saepe bellabant. Germani bellum amabant; bellum Germanos delectabat. Proelia Germanos delectabant. Etiam Romani proelia amabant. Romani copias ad pugnam vocabant. Romani arma in castra apportabant et castra firmabant. ${ }^{81}$

The 'endgültige Revision' of Ludus Latinus I - für Sexta, was followed by a revision of Ludus Latinus II - für Quinta ( $L L^{10} I I$, iv). The first quarter of the book deals mainly with Germani and their encounters with the Romans. There are several passages about the end of the Roman empire, namely König Alarich vor Rom, Alarichs Ende, Dietrich von Bern and Der Ostgoten Todeskampf am Vesuv. Germanentum in the broadest sense, including not only the Cimbri and Teutones and the Germani of Tacitus' era but also Visigoths and Ostrogoths, is the thematic connexion, and a rough historical overview beginning with Germanic resistance to Rome (and the failed Cimbric and Teutonic invasions) and ending with the invasions that toppled the empire is evident in the selection of subject matter. ${ }^{82}$

${ }^{80}$ For observations on the use of Latin terminology to make school into 'Latin country', see Waquet (2001), 8 , a discussion of France in the early $18^{\text {th }}$ century, when Latin "reigned [in school] ... as exclusive master of the terrain". The use of Latin terminology is relevant also to the German Gymnasium. Gymnasien still commonly use terms such as "Sexta".

${ }^{81}$ Each war-related word or phrase is underlined the first time it appears (my underlining). The importance of martial vocabulary was strongly linked to the prevalence of Caesar's Bellum Gallicum as an, in many cases almost the, set text for school Latin (Kipf (2006a), 28-32).

82 See chapter 4 for a table comparing the Germanic passages in Ludus Latinus II of 1934 and an edition of 1969. The rest of the 1934 edition mainly involves aspects of Roman life and culture and events from Roman history. The German passages are mainly on mythical and historical subjects (Roman, Germanic and Greek) with heroic central figures. The Germanic subjects include Hildebrand und Hadubrand and Siegfrieds Kampf mit Brunbild (marked as non-compulsory passages) (LL $\left.{ }^{10} I I, 61,66-67\right)$. 
Just like the 1932 edition of Book I, Ludus Latinus II opens with a welcome to students entering Quinta. The passage introduces the verb prodesse, putting it to the following use:

Salvete, pueri! Sextani fuistis, nunc estis quintani. Industria vobis profuit. Quintani doctiores sunt quam sextani. Nam lingua Latina mens exercetur; nibil menti tantopere prodest. Quae nunc discitis, ea postea vobis proderunt. Nam quamquam discere nonnullis displicet, tamen vobis proderit multa scire. Itaque este seduli, ut et vobis et patriae prositis! Nam virorum officium est patriae prodesse; patriae profuisse summum gaudium est senum $\left(L L{ }^{10} I I, 1-2\right)$.

This text contains a simplistic advertisement for Latin education and patriotism. In the context of a nationales Gymnasium, the former is supposed to serve the latter. The rationale for this is that nothing trains the mind more effectively than Latin. ${ }^{83}$ The aim is multa scire, in line with the oft-expounded implication that the material learnt in Latin lessons is intrinsically educational. Diligence at school and success in Latin are encouraged for patriotic reasons, which appear rather suddenly in the text. By doing their patriotic duty (the first part of which is diligent application to Latin), the boys will be able to enjoy 'summum gaudium' when they are old.

The next passage revisits the Germanenbild presented in Book I. The pupil is asked (by way of practice with interrogative pronouns) to recall important characteristics of the Germani, reinforcing the image of tall, blonde-haired, blue-eyed warriors whose life and customs were strict and moral. Their historical role is to be pitted against the Romans.

Qualis erat Germanorum statura?... Quales erant oculi, quales capilli Germanorum? Quis Germaniam a Romanis liberavit?... Victus et mores Germanorum non erant mites. Itaque viri tam fortes erant ut a Romanis superari non possent; munimenta autem eorum expugnare non poterant. Etiam mulieres proeliis intererant, ut sauciis adessent. Saepe viri a domiciliis aberant ut bellarent. Otium enim diu tolerare non poterant. Discordia Germanorum saepe Romanis profuit. Si concordiam servare potuissent, condicio eorum fuisset melior (LL, $\left.{ }^{10} I I, 2\right)$.

\footnotetext{
${ }^{83}$ Stray (2007), 6, calls this the "ideology of mental discipline, renamed by twentieth-century psychologists the transfer of training". In Germany, formale Bildung was a commonly used term that referred to the efficacy of Latin (particularly grammar) in teaching thought structures which could be applied to other areas of life (see chapter 1).
} 
Notable features include the emphasis on the Germanic lifestyle as not being soft. Along with the description of Germani as warriors comes the notion that the women came along to the battles to act as nurses to the wounded. The relevant passage of Tacitus' Germania, however, gives quite a different impression:

in proximo pignora, unde feminarum ululatus audiri, unde vagitus infantium. hi cuique sanctissimi testes, hi maximi laudatores: ad matres, ad coninges vulnera ferunt; nec illae numerare et exigere plagas pavent, cibosque et hortamina pugnantibus gestant (Tac. Germ. 7.3-4).

Here the women are frenzied supporters, counting and demanding the men's wounds, and bearing not medical aid but food and exhortations. The wildness of Tacitus' Germanic women has been understated in the adaptation.

The next passage portrays a council of war, including a speech by Arminius. The Cherusci, "et nobilissimi et humilissimi", gather together and agree to what seems very much like 'total mobilisation' ('etiam adulescentuli hodie armentur?'), then unanimously acclaim Arminius as their leader. He denounces Segestes as a traitor. In the next passage, Germanicus auf dem Teutoburger Schlachtfelde, Germanicus presents the story from the other side, telling how he has 'liberated' Segestes. The Germanicus passage describes the battlefield scene, taking some details from Tacitus' Annals 2.61-62. Germanicus swears that he will exact vengeance, but the story only goes as far as the next encounter between him and Arminius: "Postridie Romani contra Germanos ducti sunt; sed Arminium vincire non potuerunt." Because the story ends with the inconclusive wars waged by Germanicus, the fact that Arminius was eventually betrayed by Segestes and killed by his own people is omitted. Just as we have seen in the Ostermann books, Arminius remains a victorious figure, the liberator of Germania $\left(L L{ }^{10} I I\right.$, $3-4)$.

Several passages about the limes follow. The subject of Germania Romana is thus introduced, and we may note that despite the positive tone of the texts describing the 'liberation' of Germania from the Romans, romanisation of the west bank of the Rhine is also presented favourably. It is usual for a positive view of romanisation in the provinces, including Germania Romana, to be espoused by Latin schoolbooks. A negative view, after all, would perhaps undermine the notion of the superiority of classical culture and a 'classical' education. It is not Roman expansionism as such that is negatively portrayed, but the actions of Quintilius Varus, who is the villainous oppressor of the Germani. 
Varus severus in Germanos erat; iniuste iudicabat, superbe imperabat, crudeliter puniebat.

Iniurias eius illi patienter tolerare non poterant. Itaque miserum interitum ei paraverunt.

Varus bears the blame for his own demise, while romanisation of the Rhine's west bank comes across very favourably. Velleius' account emphasises Arminius' treachery as well as Varus' lack of consilium, while hinting at Varus' greed (Vell. Hist. 2.117-118, 120). The version presented here, however, downplays Arminius' treachery and puts more emphasis on Varus' greed. Meanwhile, romanisation itself is presented in a positive light.

Sinistram autem Rheni ripam Romani diligenter custodiebant. Eas regiones tam prudenter administrabant, ut celeriter incolarum animos sibi conciliarent. Ibi agricolae libenter et strenue agros curabant. Ibi oppida condita sunt, quae Romani pulcherrimis aedificiis liberaliter ornabant $\left(L L{ }^{10} I I, 5\right)$.

The passage "Die Römer als Kaufleute und Lebrmeister der Germanen" addresses the fact that Romano-Germanic relations were not entirely bellicose, and that Roman influences pervaded Germania libera. The Germani enjoy a variety of luxuries brought by the Romans:

\begin{abstract}
Magnopere maiores nostri pretiosis vestimentis delectabantur, magnis poculis aureis argenteisque, maxime vero vino et armis ferreis... Nulla gens usum tegularum, fenestrarum, murorum tam facile a Romanis didicit quam Germani. Propterea Romani non falsi magistri Germanorum nominantur (LL $\left.{ }^{10} I I, 6-7\right)$.
\end{abstract}

A completely unjustifiable claim is made, that no people learnt from Roman sophistication so easily as the Germani ("maiores nostri"). The role of the Romans as magistri Germanorum provides a model for the pupils as classically-educated Germans. The phrase "maiores nostri" recurs in a passage about the Saalburg, which is followed by a gleeful description of its sack: “... a maioribus nostris [Romani] devicti et propulsati sunt illudque castellum, quod supra descripsimus, circumventum, expugnatum, inflammatum est" (LL $\left.{ }^{10} I I, 8\right)$. Pupils are thus supposed to feel pride in the warlike virtues of the Germani (their 'ancestors') but to acknowledge the superiority of Roman civilisation - which is, after all, the reason for their being in the classroom.

Ludus Latinus, in keeping with the requirements of Kulturkunde, employs the Germani as proto-Germans and raises them to a new level of prominence in the early stages of Latin 
learning, amongst a large and eclectic variety of German subject matter. The Germani are one of the points of identification intended to help pupils engage with the subject. The characteristics of the Lesebuchgermanen, as seen in the Ostermann textbooks, remain essentially unaltered. Since the $19^{\text {th }}$ century, Latin classes had been defined by 'Grammatike und Krieg', and in Ludus Latinus Germanic warriors are supposed to incite the admiration of Latin pupils. At the same time, the Romans are to be remembered as the bringers of civilisation to the western bank of the Rhine. Ludus Latinus, in line with the nature of the Gymnasium, for which it was intended, is determinedly deutschnational. 
The topics of Germania and the Germani gained their greatest ever prominence under the Third Reich as they were used to promote Nazi racial ideology. Allan Lund, Karl von See and Ruth Römer have published research into the Germanenideologie of National Socialism and its precursors in the development of racialised thought and the application of racial theories to Indo-European linguistics, ancient history, prehistory and classical philology ${ }^{84}$ What follows is a brief outline of relevant features of National Socialist Germanenideologie and educational policy and an analysis of the way the Germani are portrayed in several new textbooks approved by the Nazi regime. ${ }^{85}$

The oppositional model of Germane versus Römer (see introduction) was appropriated by proponents of racial theories who used Indo-European studies (Indogermanistik) to assert the existence of an Indo-European Herrenvolk or Herrenrasse destined to conquer and rule others. The opponent of the Indogermane (or Arier), was identified as the Semite or else Vorderasiate, to whom the weak, effeminate and decadent qualities of the old Roman stereotype were applied. ${ }^{86}$ All that was good in history was to be attributed to the Indogermanen, the opposite to the 'vorderasiatische Gegenrasse', and many German researchers attempted to prove a special link, based on continuity of language, culture and descent (or race) between the earliest Indogermanen and modern Germans. Klaus von See shows how the established Germane versus Römer antithesis, developed into an Indogermane versus Semite antithesis or, in other words, Arier versus Jude, supported antisemitism, ${ }^{87}$ which was a central and defining point of Nazi ideology and its popular political manifestations. ${ }^{88}$ Most prominently, Gustaf Kosinna, who was widely celebrated during the Third Reich, attempted to prove that the Indo-Europeans originated in Northern Europe, in Denmark. ${ }^{89}$

\footnotetext{
84 See bibliography for: Von See (1970, 1972, 1994, 2006); Lund (1991a, 1995); Römer (1989). See also the contributions of Muhlack, Beck, Fuhrmann, Kroeschell and Fischer in Jahnkuhn, Timpe ed. (1989).

85 Third Humanism (Dritter Humanismus) was a new philosophy of education which attempted to renew the importance of the ancient languages for education by developing the concept of paideia based on ancient Greek society and literature. The movement's foremost representative was Werner Jaeger. While it was an important development in educational theory and the justification of the Humanist Gymnasium, and has been suspected of implication in National Socialist ideology, it is of little relevance to the portrayal of the Germani in textbooks and is therefore omitted from the discussion at hand. For further information on its role in relation to contemporary politics and ideology, see Fritsch (2001), 224-242.

86 The terms Arier and Indogermane were each used differently by different writers and politicians at different periods. This is not the place for a detailed discussion. Von See (2006), 9-54, describes the uses of the term Arier from the early $19^{\text {th }}$ century to the end of the Third Reich in philological and political circles. See also Lund (1995), 29-3, 89.

87 Von See (1970), 85ff.

${ }^{88}$ Fritsch (1982), 27-28.

89 Kosinna's work was mostly based on the following false premise: "Scharf umgrenzte archäologische Kulturprovinzen decken sich zu allen Zeiten mit ganz bestimmten Völkern oder Völkerstämmen." Kosinna projected
} 
The most influential racial ideologues of National Socialism were Alfred Rosenberg and Hans Günther, who re-interpreted history in terms of Aryan self-assertion against inferior Semitic or Near-Eastern races. While the 'classical' Greeks were universally admired, attitudes to the Romans were mixed. While the early Romans were described as Nordic, and certain figures from the nobility identified as Nordic heroes, Rome was said to have fallen under 'Near-Eastern' influence, including that of the Etruscans. ${ }^{90}$ Roman conflict with the Germani elicited disapproval. ${ }^{91}$ On the other hand, the Romans' state-building and successful conquests were viewed as Nordic traits, as reflected in educational policy (EUhS, 233). ${ }^{92}$ The fall of the Roman Empire was presented as the triumph of Nordic Germani over racially degenerate Romans. ${ }^{93}$ Since the classicism of Goethe's period there had existed the idea of a special bond between Greeks and Germans, which was now interpreted racially. ${ }^{94}$ It should be emphasised that National Socialist views on ancient history were by no means uniform (and were certainly contradictory in many respects). Hitler had little interest in Germanic prehistory and, at least privately, considered ancient Germanic culture embarassingly primitive compared with Greek and Roman achievements. ${ }^{95}$ The Germani, furthermore, were not the only ancient peoples to be appropriated as ancient ancestors of the Germans, and Hitler claimed, "Wenn man uns nach unseren Vorfabren fragt, müssen wir immer auf die Griechen binweisen." ${ }^{96}$ While the Greeks were, in theory, more important models than the Romans, Latin retained its pre-eminence over Greek in the classroom. ${ }^{97}$

Germanic and Indo-European habitation in Northern Europe back much earlier than can reasonably be proven and extended the identification of particular cultures as Germanic and Indo-European more widely than is justifiable, and his claims were cited as Nazi Germany claimed territory to the East (Römer (1989), 8081). Kosinna's theories of Germanic continuity also implied racial and spiritual continuity (Lund (1995), 9096).

90 Rosenberg (1934), 74, 96 as discussed by Apel, Bittner (1994), 258.

91 Marius, for example, is denigrated by Günther as an "Adelshasser" and a "fälisch-ostische Rassenmischung" because he carried out reforms against the will of the senate and because he destroyed the Cimbri and Teutones, Günther (1929), 93f. See Apel, Bittner (1994), 263.

92 See below.

93 The fact that tribes such as the Visigoths and Ostrogoths were quite different from the Germani of Caesar's and Tacitus' periods is a complication that receives relatively little attention. The attribution of 'Aryan' or 'Nordic' status became the important factor.

${ }^{94} \mathrm{Kipf}(1999), 221$.

95 "Warum stoßen wir die ganze Welt darauf, daß wir keine Vergangenheit haben? ... Himmler ... gerät in Begeisterung über jeden Tonscherben und jede Steinaxt, die er findet. Wir beweisen damit nur, daß wir noch mit Steinbeilen warfen und um offene Fenerstellen bockten, als sich Griechenland und Rom schon auf böchster Kulturstufe befanden. Wir bätten eigentlich allen Grund, über diese Vergangenheit stille zu sein. Statt dessen hängt Himmler das alles an die große Glocke. Wie müssen die heutigen Römer verächtlich über diese Enthüllungen lachen!' Speer, A., Erinnerungen (1976) Frankfurt a.M., 108. In a public speech in Karlsruhe on 5 December 1934, however, Hitler said the following: "Wir sind den Römern oder Griechen, den Galliern oder Briten und ibren heutigen Nachfolgern keinen größeren Dank für irgendwelcher Kulturgüter schuldig, als sie uns. Wir brauchen uns unserer Vorfahren ebensowenig zu schämen, wie sie sich der ibrigen. Wir können vielmehr darauf hinweisen, daß die Germanen schon 1000 Jabre, bevor Rom gegründet wurde, einen kulturellen Hochstand erlebt haben." Cited by Lund (1995), 103, with reference to: von Richthofen, B., Die Vor- und Frühgeschichtsforschung im neuen Deutschland (1937) Berlin, 44; also in introduction by W. Hülle to $7^{\text {th }}$ edition of Kosinna, G., Die deutsche Vorgeschichte - eine hervorragend nationale Wissenschaft (1936) Leipzig, iii.

96 Related by, amongst others, Picker, H. Hitlers Tischgespräche im Führerhauptquartier (1976) Stuttgart, 85 and cited by Scobie (1990), 13. Hitler's plan to re-name Berlin 'Germania' shows that his admiration of the ancient Mediterranean world extended so far as to lead him to consider applying a Latin name to the planned 
Heinrich Himmler and the SS founded the Abnenerbe organisation in 1935 to conduct research into Germanic antiquity and racial history. Himmler was considerably more interested than Hitler in Germanic antiquity. The Latinist Rudolf Till received sponsorship to produce a facsimile and critical edition of Germania, which was published in 1943 with a foreword by Himmler. ${ }^{98}$ In the 1920s and 1930s three commentaries on Germania appeared in a short space of time: those of Fehrle $\left(1929 ;{ }^{2} 1935 ;{ }^{3} 1939 ;{ }^{4} 1944\right)$, Reeb (1930) and Much (1937). ${ }^{99}$ Fehrle was a member of the SA and later the SS, and was regarded as "NSVolkskundechefideologe". ${ }^{100}$ Racial ideology informs Fehrle's whole approach to Germania:

Vollständigkeit habe ich nicht angestrebt. Es kommt mir vor allem darauf an, die Erbwerte zu betonen, die auch beute noch in unserem Volke leben und allezeit Grundlagen unserer sittlichen Haltung sein werden. ${ }^{101}$

He describes the Germani as representatives of arisches Bauerntum and considers Tacitus to have had a deep, racially-determined understanding of the Germani:

Aus diesem altarischen Bauernblut des Tacitus und seiner rassischen Verbundenheit mit uns ist sein Verständnis für unsere Abnen zu erklären. ${ }^{102}$

The following passage outlines the appropriation of Germanic history and prehistory as 'national' disciplines:

Die Germaniaforschung ist im Weltkriege und nachher immer neu belebt worden... Das deutsche Volk kam in dem gewaltigen Ringen zu sich selbst. Weitsehende Männer mit völkischer Haltung sahen ein, daß Deutschlands Erneuerung vom eigenen Volkstum ausgehen müsse. Deshalb suchte man aus Gegenwart und Vergangenheit germanischdeutsche Art zu erforschen und für das Gestalten unserer Lebenshaltung nutzbar zu machen. Bei diesen Bestrebungen ist die Frühgeschichte unseres Volkes von hervorragender Bedeutung. Denn in der Frühzeit ist unsere Kultur noch nicht durch so viel Entfremdungen

German 'Welthauptstadt' (Scobie (1990), 112). In Mein Kampf, Hitler wrote, "Der Kampf, der heute tobt, geht um gan₹ große Ziele: eine Kultur kämpft um ibr Dasein, die Jahrtausende in sich verbindet und Griechen- und Germanentum gemeinsam umschließt." Hitler (1934), 470.

${ }_{97}$ Neither Latin nor Greek was such a high priority as to warrant such a difficult and expensive change in policy as placing Greek ahead of Latin in schools.

98 Schama (1995), 79.

99 Städele (1997), 523.

${ }^{100}$ Lund (1995), 32.

${ }^{101}$ Fehrle (1939), xv.

102 Fehrle (1939), xv. 
umgestaltet wie später. Bei Erforschung der Frühzeit steht die Germania des Tacitus an erster Stelle. ${ }^{103}$

School editions and commentaries were subject to the practical requirements of explaining linguistic difficulties, and ideological influences are usually less prevalent, though a commentary by Hugo Zimmermann includes the following statement of intent:

\section{Es kommt uns hierbei in erster Linie darauf an, die Ewigkeitswerte unseres Volkstums aufzuzeigen, die als Eigenschaften in unserem Blute liegen, in den großen Zeitläufen der Geschichte immer wiederkehren und Richtung weisen. ${ }^{104}$}

Between the National Socialists' coming to power in 1933 and the promulgation of a comprehensive educational decree, Erziehung und Unterricht in der höheren Schule, ${ }^{105}$ on 29 January 1938, there was piecemeal reform, much of it towards the Vereinheitlichung des böheren Schulwesens, a drive to reduce the number of school systems operating in Germany, which had approached 70 during the Weimar Republic. ${ }^{106}$ Many representatives of the Humanist Gymnasien, fearing further marginalisation or even abolition of their school system, attempted to promote instruction in the ancient languages as a form of 'Nationalbildung' compatible with National Socialist politics and ideology. ${ }^{107}$

Erziebung und Unterricht established the single-sex Oberschule as the main type of secondary school. For boys there were a grundständige Form encompassing the fifth to the twelfth years of school and an Aufbauform starting in the seventh year. ${ }^{108}$ In the former, English was compulsory from year 5 and Latin from year 7. The Aufbauform had compulsory English from year 7 and Latin from year 9. ${ }^{109}$ In the grundständige Oberscbule for girls, only English was compulsory (from year 5). The Oberstufe offered a home-economics branch and a linguistic branch, the latter giving the option of Latin and a modern language from year 10. The Aufbauschule for girls had no Latin as home economics was the only course available.

\footnotetext{
103 Fehrle (1939), xii-xiii. Gustaf Kosinna published, in 1912, a work which (before the First World War) exemplified the attitude Fehrle describes, with the title Die deutsche Vorgeschichte, eine hervorragend nationale Wissenchaft (1912) Würzburg.

104 Zimmermann $\left({ }^{4} 1943\right)$, as cited by Koller (1989), 95; I have been unable to find details about this edition beyond those cited by Koller.

${ }^{105}$ Hereafter referred to as Erziehung und Unterricht or EUhS.

106 Flessau (1977), 21. Fritsch (1982), 20-23.

${ }^{107}$ Fritsch (1982), 22. Nickel (1972), 485-503, provides a large number of citations from representatives of the Humanist Gymnasien, especially in the years before the definitive decree Erziehung und Unterricht in der böheren Schule of 1938.

108 The Aufbauform was designed for pupils transferring from other kinds of school into the Oberschule.

109 In the Oberstufe (years 10-12) boys had a scientific and a linguistic option, the latter offering a second modern language (French, Italian or Spanish).
} 
The Humanist Gymnasien remained in existence, but they were marginalised, without the prestige that they had enjoyed in the $19^{\text {th }}$ century. Whereas there had been 300 Humanist Gymnasien in Prussia in 1900 there were only 100 in Germany in 1938, about 13\% of all secondary schools for boys. ${ }^{110}$ Those who had hoped to see the Humanist Gymnasien rise to pre-eminence as a Nationalschule that would provide Germany with its future elite were disappointed. ${ }^{111}$ It should be borne in mind that the plans outlined in Erziebung und Unterricht were never fully implemented because of disruptions caused by the Second World War. $^{112}$

"Nationalismus, Rassismus, Fübrerkult, Totalitarismus und Miltarismus" were the guiding principles of National Socialist education. ${ }^{113}$ "Das nationalsozialistische Erziehungssystem ist seinem Ursprung nach nicht ein Werk der pädagogischen Planung, sondern des politischen Kampfes und seiner Gesetze" (EUhS, 11). The educational philosophy of Neubumanismus was turned on its head as the purpose of education was changed from developing the individual's personal and intellectual autonomy to schooling the younger generation in conformity and obedience to the state. The word 'Volksbildung' signified not the education of the Volk, but the moulding, or even creation, of the Volk through education. ${ }^{114}$

Building on the Kulturkunde or Deutschkunde movement of the Weimar Republic, German, History and Geography, as "deutschkundliche Fächer", were identified as the most important. Erziebung und Unterricht listed Germanic heroes to be presented in History class, starting with Adolf Hitler and "Helden der nationalsozialistischen Erbebung und des Weltkriegs" and going back to "Armin" - making Hitler the culmination of a mythical Germanic destiny that began with Arminius' defeating the Romans in AD 9 (EUhS, 76). All ancient and modern history was to be interpreted according to the concepts "Rasse" and "nordische Schöpferkeraft" (EUhS, 91-2). ${ }^{115}$ Racism was the central unifying principle of the whole Nazi educational plan as outlined in Erriehung und Unterricht. ${ }^{116}$

\footnotetext{
110 Apel, Bittner (1994), 345.

111 Nickel (1972), 489-490 cites recommendations that the Humanist Gymnasium, as "vorbildliche Kraft des nordischen Geistes für die Erziehung deutscher Führer" be made the training ground for Germany's future leaders by instructing them in "Rassenbewußtsein" that will oppose them to liberalism, democracy and the 'Oriental' influence of Bolsheviks and Jews (see Apel, Bittner (1994), 345). While the Gymnasium remained for academic training, the future party leaders and political elites were to be groomed in a small number of Adolf-HitlerSchulen (see Flessau (1977), 16).

112 Fritsch (1982), 23. Schmidt (2001), 297-298 points out that despite the enthusiasm of some academics for National Socialism (particularly Hans Drexler and Hans Oppermann and, with reference to Germania, Rudolf Till), the space of just six years before the outbreak of the Second World War did not allow for anything like a complete ideological takeover of university Latin studies.

113 Fritsch (1982), 26.

114 Flessau (1977), 67.

115 Flessau (1977), 81.

116 Fritsch (1982), 27-28.
} 
Erziebung und Unterricht prescribed Rassenbewußtsein as a leading justification for teaching Latin and Greek, which were identified as the languages of Nordic races. Instruction in Roman and Greek language, history and culture was supposed to strengthen pupils' "nordische Geistesrichtung" (EUhS, 231). The aim of school Latin was "ein Erkennen und Verstehen der Haltung des Römers, durch die dieses nordisch bestimmte Volk in einer bedrohenden Umwelt durch Schaffung seines Staates sich selbst behauptet hat" (EUhS, 233). The Germani were allotted a particularly important place in the Nazi guidelines for Latin. In all types of school, instruction in Latin should ultimately lead to the "Darstellung Germaniens und der römisch-germanischen Zusammenstöße bei Cäsar und Tacitus", with reference to "die eigentümliche deutsche Stellung inmitten der Völker Europas" and the "Hauptaufgabe der Selbstbehauptung, die diese Stellung uns auferlegt". Teaching should also show "die Bedeutung Roms fur die Entstehung eines römischen Zivilisationsbewusstseins" and present "die Eigentümliche Stellung Deutschlands... als Schicksal und Aufgabe" (EUhS, 233). ${ }^{117}$

Never before nor since have the educational authorities required such a disproportionately heavy emphasis on the Germani for their own sake. The set readings for schools (especially those schools that spent the least time on Latin) were severely skewed in favour of Tacitus' and Caesar's texts involving the Germani. The thematic emphasis prescribed for readings is reflected in the subject matter of textbooks for language learning. ${ }^{118}$

Erziehung und Unterricht reduced the time allotted to Latin in schools. Gymnasium pupils now received 35 Wochenstunden of instruction over eight years, down from 53. Economising on material was necessary. Reading must be focused as far as possible on ideologically significant texts and themes. One solution was to group selected and excerpted readings around desired themes - a teaching strategy that had only been tried to a limited extent before and which, after the war, first appeared again in the 1960s. Themes to be covered included Alt-Rom (which fitted the notion that the early Romans were true Aryans before Eastern influences took hold), Das Werk des Augustus (which promoted the concept of racial renewal under a Führer-figure) and Die Darstellung des Germanentums bei Caesar und Tacitus. ${ }^{119}$

\footnotetext{
117 Fritsch (1982), 29.

118 It is worth noting that the biased historical emphasis on Roman-Germanic encounters (that is, wars) was already present in Ludus Latinus I and II. Under the Third Reich, however, this bias was part of a systematic attempt to make Indogermanic/Aryan/ Germanic Selbstbehauptung the guiding thread of world history.

${ }^{119}$ Fritsch (1982), 52-54. Many selections of texts were available. By way of example, the press Velhagen und Klasing published a series, Lateinische und griechische Lesehefte, which included such titles as: Die Entdeckung Germaniens und der Germanen - Quellenzengnisse aus der Antike; Germanenkunde - Zeugnisse aus spät- und mittellateinischen Quellen; Tacitus' Germania; Julius Civilis - Der Freiheitskampf der Bataver, and Arminius - Sämtliche lateinischen Zeugnisse zur Geschichte des Befreiers Deutschlands, dazu die griechischen in Übersetzung.
} 
Documented school inspections from the Rhine Province during the Third Reich show Tacitus to be the most widely read author, being taught in $27.5 \%$ of inspected lessons with Germania, the Annals and the Histories roughly evenly represented. Caesar's Gallic War and Livy each feature in 20\% of lessons, and Cicero and Virgil in 7.5\% each, while other authors being read include Terence, Ovid and Horace. ${ }^{120}$

Erriebung und Unterricht required the replacement of old teaching materials. The following is an analysis of three new approved works for different types of school. They will be introduced individually and then trends and themes from the various works will be discussed. Generally we encounter the same features of the "Lesebuchgermanen" familiar from Ostermann, Ludus Latinus and other earlier textbooks, so particular emphasis will be placed upon elements of Nazi ideology embedded in the textbooks' Germanenbild.

In identifying National Socialist influences on textbooks, one must remember that the practical purpose of the texts still takes precedence. The primary concern of the authors always had to be linguistic instruction. In addition, the features of the traditional Lebrbuchgermanen that had long provided points of reference for nationalist justifications of Latin teaching could be carried over wholesale into the new textbooks. Although many aspects of the new textbooks' portrayal of the Germani and the ancient world in general are compatible with the ideology of National Socialism, the differences from earlier textbooks are often noticeable only in matters of emphasis and specific references to ideological doctrines are relatively infrequent, though they do occur and will be discussed below.

The Lateinisches Unterrichtswerk edited by Ludwig Mader and Otto Wecker reflects the requirement to match the new Richtlinien "nach Inhalt, Aufgabestellung und Umfang" (Lat. Unt. MW $I A, \mathrm{v}){ }^{121}$ The book was approved for use at Oberschulen by boys learning Latin from their seventh year of school. Wecker, the main author, was a proponent of the inductive approach to learning grammar. ${ }^{122}$ There is a fairly wide variety of subject matter, including fables and Greek as well as Roman myth and history. The focus is more firmly on antiquity than was the case in Ludus Latinus, though politically motivated references to the present day are notable in a few instances. The introduction states,

\footnotetext{
120 Apel, Bittner (1994), 307.

121 The book will hereafter referred to as Mader-Wecker or Lat. Unt. MW. The 'A' version was intended for use in Oberschulen for boys.

122 Fritsch (1982), 35.
} 
Der Stoff der Lesestücke will in einem ersten Gang in die römische und antike Welt einfübren und zugleich diese Welt als uns nah erscheinen lassen, trotz ibrer zeitlichen und sacblichen Ferne (Lat. Unt. MW I A, v).

The motivation of this approach is to ease the pupils' introduction to the ancient world by making it seem closer to the modern world - and as we have seen before, Germany and Germania are chosen as the points of identification. The first ten lessons are entitled: Von Deutschland; De Italia et Graecia; De Diana, Latona, Niobe; De Rheno; De Germanis antiquis; Fortsetzung; Römische Überreste in Deutschland; De castris Romanis; Von der Saalburg; Nach dem Besuch der Saalburg. The topic of Roman forts in Germania recurs throughout these passages, bringing Romano-Germanic wars to the fore. ${ }^{123}$

The first collection of loosely-connected sentences in volume I, headed "Von Deutschland", contains the familiar elements of a Lateinbuch introduction to Germania/Germany:

Germania est patria nostra. Quis Germaniam non amat? Cui patria non placet? Gloria Germaniae magna est. Germaniae vicina est Gallia. Silvae Germaniae magnae sunt et incolas delectant. Poetae silvas laudant. Bestiae silvarum agricolis nocent... (Lat. Unt. MW I $A, 3)$.

There is an immediate appeal to patriotism and glory. The forests are presented as a delight to the inhabitants, though we are also told that the wild beasts of the forests are noxious to the farmers. The familiar textbook topos of poets who praise the fatherland appears here and on page 5 ("Germanorum poetae et castella amoena et bona vina Rheni celebrant) - presumably a reference to modern poetae Germanorum.

The next passage, headed "De Italia et Graecia" clearly refers to the racial theories used as the basis for the Latin Lehrplan in Erriehung und Unterricht. A teacher is asked why he is teaching his class Latin and replies, "Multis de causis vos linguam Latinam doceo; unam nomino. Lingua nostra et lingua Latina et lingua Graeca ex una familia linguarum derivatae sunt." He is thus referring to the ancient connexion between the Italic, Greek and Germanic branches of the Indo-European language family. He goes on to say, "Incolae Italiae et Graeciae olim cum incolis Germaniae in una terra babitabant." This claim is only explicable in the context of theories about shared Indo-European/Nordic/Aryan origins that sprang from the conflation of

123 See also Lat. Unt. MW I A, 14-15 "Nächtlicher Angriff”, which is accompanied by a relief from Trajan's column with the caption "Germanen im Angriff gegen Römer." 
ethnic and linguistic groups, and the appropriation of Indogermanic studies for the purposes of racial ideology. ${ }^{124}$ The textbook justifies the teaching of Latin by reference to the Nordic connexion outlined in Erziehung und Unterricht without specifically using any of the key-words associated with this ideology. The passage cited also includes a reference to recent history (“Cum incolis Italiae nuper amicitia renovata est'), as if the fact had relevance to the ancient context - another result of the conflation of ancient and modern through the theory of racial continuity (Lat. Unt. MW I A, 4). ${ }^{125}$

While the very ancient links between Latin and German are presented as a good reason for modern-day German pupils to learn Latin, more recent contact between the languages appears later in the same book in a negative light. A passage headed "Unsitte in Familiennamen; Berufsnamen" states the following:

\section{Olim apud maiores nostros mos malus erat, ut viri docti vocabula sermonis Latini usurparent et sermoni patrio immiscerent; nam sermonem patrium in magno bonore non babebant (Lat. Unt. MW I A, 15).}

It goes on to describe the practice of using Latin translations of German surnames taken from people's professions. The pupils are presented with the Unsitte of viri docti, whose appropriation of Latin words is a slight to the German language - a parochial attitude at odds with the long-standing justification of Latin teaching on the grounds that much German vocabulary had been borrowed from Latin. ${ }^{126}$

The Germani in Mader-Wecker are described in conventional terms in sentences borrowed primarily from Tacitus' Germania and adapted. The only notable exception is the statement, "Ferrum rarum erat; aurum autem et argentum magni aestimabantur", which contradicts the common stereotype of the Germani as careless of wealth (Lat. Unt. MW I A, 5). Germanic patriotism is expressed in particularly strong terms in passage 6: "Germani patriam terram sacram (esse) putabant, quamquam caelum Germaniae asperum et ager Germanus piger erat' (Lat. Unt. MW $I A, 6)$. By way of introducing present passive verb forms, the next passage places words in the mouths of a teacher and student: "V alde delector, cum... nobis de Germanis narras,

\footnotetext{
124 Römer (1989), 62-102. Von See (1970), 85 ff.

125 The Romans and Greeks are also summarily characterised: "Roma et disciplina et gloria bellica clara erat, Athenae et doctrina et litteris florebant" (Lat. Unt. MW I A, 4).

${ }^{126}$ Mader-Wecker has the following summary at the end of its " $A$ B C des Übersetzens": "In diesem Umdenken und eigenen Nachgestalten liegt ein wertvolles Mittel, die eigene Ausdrucksfähigkeit in der Muttersprache gerade auch am Lateinischen zu schulen. Deutscher, lerne deutsch - auch am Lateinischen?' (Lat. Unt. MW I, 97) Erziehung und Unterricht outlines the purpose of learning Latin as the improvement of one's German through contact with the mighty "Sprachgeist" of Latin (EUbS, 235).
} 
magister! A cunctis laudaris, nam cuncti valde delectamur." - "Gaudeo, quod... delectamini” (Lat. Unt. MW $I A$, 6). Similarly, the description of Germanic victories over the Romans is supposed to excite feelings of pride and incite pupils to emulate such warlike deeds: "Tamen castellum expugnatum et deletum est. Nonne laudabitis proavos? - Etiam vos adversarios superabitis, si viri estis! An... superabimini? An tu fugeberis, Carole? Numquam superabor, numquam fugabimur!" (Lat. Unt. MW I A, 7). A Roman and a Germanic boy, who can perhaps be regarded as early examples of Identifikationsfiguren, appear in another passage where the latter asserts the commonplace that despite the harsh climate the Germani love their homeland better than the Romans love theirs. ${ }^{127}$ The intended strong identification with the Germani is again evident in the passage "Familien- und Ahnengeschichte" which reflects Nazi ideology regarding Aryan ancestry and, by way of practising indirect questions, slides from an interrogation about recent ancestors ("Scisne quis avus tuus fuerit? ubi natus sit? ubi habitaverit?" and questions in a similar vein) directly onto the subject of the Germani:

Narrate quid de proavis nostris audiveritis! Scitisne, ubi Germani antiqui habitaverint?... cur Germania antiqua Romanis non placuerit? quibus rebus Germani Romanos terruerint? ubi exercitus Vari deletus sit? (Lat. Unt. MW A I, 11).

The cover of Exercitium Latinum (1941) is adorned with a Roman eagle from the time of Trajan which is presumably favoured because of its striking similarity to one of the favoured Nazi designs of the German Reichsadler. ${ }^{128}$ The author, Gerhard Röttger, had also produced a revised volume of Ludus Latinus in 1938, which was a conflation of volumes III and IV of the textbook's Bavarian version, intended for use in the reduced circumstances under which Latin found itself following the decree Erziehung und Unterricht. The eagle appeared also in that volume as an illustration $\left(L L^{12 / 9} I I I / I V ~ B, 16\right)$. Exercitium Latinum is intended for Aufbauschulen and Mädchenschulen with between one-and-a-half and two years of grammatical instruction. It is therefore particularly condensed and restricted to the necessities (EL, iii). The foreword promises a similar approach to other textbooks of the time.

Der Inhalt der Stücke ist der römischen Sage und Geschichte entnommen und sucht durch Schilderung großer Ereignisse und bedeutender Persönlichkeiten zugleich die wesentlichen

${ }^{127}$ For Identifikationsfiguren (characters in textbooks, generally children, with whom pupils are supposed to identify) see chapter 5 , where there is also a discussion of Germanic patriotism in textbooks as a corruption of Tac. Germ. 2.

${ }^{128}$ The book will henceforth be referred to as Exercitium or EL. The source of the eagle device is given in $L L$

${ }^{12 / 9} \mathrm{III} / \mathrm{IV} \mathrm{B}$, viii. ' $\mathrm{B}$ ' in this instance denotes the Bavarian version of the book. 
Züge des Römertums sichtbar zu machen. Während der erste Teil der Stücke im allgemeinen frei komponiert ist, schließen sich die späteren in steigendem Maße an Originalabschnitte an, jedoch immer nur, soweit es der jeweilige Übungszweck, der stets vordringlich ist, zuläßt. Die letəten Stücke schaffen den unmittelbaren Übergang zu Cäsar (EL, iv).

Perhaps because of its particular emphasis on keeping to the 'essentials', the subject matter of Exercitium Latinum is more strongly weighted towards martial and Germanic topics than the less compressed works for Oberschulen. Of the 59 chapters, eleven are concerned with the Germani, of which most (eight) are among the 'freely composed' passages making up roughly the first half of the book.

Fundamenta Linguae Latinae (version A, 1942) edited by Hans Rubenbauer and Max Leitschuh was also intended for boys taking Latin from their seventh school year at Oberschulen. ${ }^{29}$ The introduction describes the selection of subject matter as follows:

Es wurde Wert darauf gelegt, hier vor allem historische und kulturgeschichtliche Belehrung über Rom und Germanien in reichem Maße zu bieten, um so auf die Historikerlektüre vorzubereiten (FLL $I^{5} A$, iii).

In Fundamenta, the "Vorïbung", the opening sentences that familiarise the pupils with some of the endings, immediately introduce Varus and Arminius doing exactly what Varus and Arminius are expected to do:

Arminius pugnat.

Arminius et $V$ arus pugnant.

Was tut Armin?

Was tun Armin und V arus?
Armin këmpft.

Armin und V arus kampfen.

pugnat $=$ er këmpft.

pugnant $=$ sie kämpfen.

Arminius et Sigimerus pugnant, sed Flavus non pugnat... Varus clamat: "Cur non pugnatis, Romani? Cur desperatis?" - "Frustra pugnamus; nam Arminius nos superat." ... "Nos pugnamus et speramus; cur vos desperatis? Sperate! Arminius vos liberat. - Germani orant: "Serva et libera nos!"- Pugnate et laborate! (EL, 1).

${ }^{129}$ Hereafter, Fundamenta or FLL. 
Apart from one passage entitled Drei römische Göttinnen, the practice sentences and passages continue in much the same bellicose vein. Among the first verb forms learnt are the present tense imperatives, as in the selections quoted above. The first few pages of the book therefore include many orders, most of which, utilising the limited vocabulary so far available, are warlike in nature: "Serva et custodi nos!" "Doce nos pugnare et triumphare!" "Parate patriae gloriam!” (EL, 2). Wehrgeistige Erziehung was a particular concern of National Socialist education, and the predominance of warlike subject matter, which followed longstanding precedents in traditional Latin textbooks, suited this purpose. ${ }^{130}$ Arminius' revolt against Varus is related in terms of a national uprising (see chapters 1 and 2), a reading also evident in Lat. Unt. MW A I, 27 and Lat. Unt. MW A II, 3; the latter treats the epithet liberator Germaniae as if its origin were among Arminius' compatriots, when in fact it originates in a rhetorical passage of Tacitus' Annals (2.88.2). ${ }^{131}$ The Nazi model of world history portrayed the Nazi takeover of power as a nationale Erhebung and presented the Fübrer as the most recent in a line of Germanic leaders going back to Arminius. The interpretation of Arminius' revolt as an expression of the will of the Volk to be free was not a National Socialist innovation, but rather the appropriation of an existing interpretation of the event which fitted National Socialist historical models.

The 1942 edition of Fundamenta Linguae Latinae has had some of the more difficult grammatical features removed from an earlier version and the vocabulary has been focused more closely on requirements for reading Caesar (FLL $I^{5} A$, iii-iv). This also means that the vocabulary has become more focused on the Latin of war. War is the main topic of ten of the 38 passages and features in many others, sometimes unexpectedly as in the passage headed Römische Art:

\section{Romam, patriam populi Romani, alta templa et magna fora ornant. Romani antiqui patriam (suam) amant. Iusti et firmi sunt. Magnus est numerus adversariorum, sed Romani adversarios non timent. Itaque de victoria numquam desperant, sed multis bellis non solum ceteros populos Italiae, sed etiam Graecos, Gallos, Brittannos superant. Germanos autem frustra terrere student. Arminius enim Germaniam magna pugna}

\footnotetext{
130 Kipf (1999), 239-241, mentions wehrgeistige Erziehung and paramilitary programmes in physical education classes and the Hitler Youth, and discusses interpretations of Herodotus which promoted a warlike Weltanschaung and the Führer principle.

131 Timpe (2006=1999), 436-437, observes that what was a "literarisch vorgeprägt [e] Wendung" is still often regarded as an "Ausdruck persönlicher Bewunderung", one which "generationenlang als inappellables Urteil der Geschicbte betrachtet und das in diesem Sinne auf das Hermannsdenkmal bei Detmold geschrieben wurde." It is, he points out, highly unlikely that Arminius would have been regarded by himself or any of the Cherusci as the liberator of Germania, as Germania was a term invented by the Romans and the so-called 'Germani' are unlikely to have identified themselves by this Roman exonym.
} 
liberat. Tamen magnum animum populi Romanorum antiquorum laudare non dubitamus (FLL $\left.A^{5} I, 5\right)$.

Here, the Romans' patriotism, courage and conquests are presented as exemplary. The passage attempts to find the requisite balance between assertion of Germanic superiority and the admiration for the Romans that justified the study of their language and culture.

While the contrast between Romans and Germani could be portrayed so as to emphasise Roman degeneracy and simple Germanic virtue, the contrast could also present the Romans as rational and civilised, the Germani as wild and primitive. ${ }^{132}$ Germanophilia led to attempts to deny or discredit the negative portrayal of the Germani as barbarians. A 1937 exhibition in Berlin-Charlottenburg entitled Lebendige Vorzeit, which had as its patrons the Reichsleiter and major Nazi ideologue Alfred Rosenberg and Reichsarbeiter Wilhelm Hierl, set out in to dispel the "Barbarenlüge über die Germanen.",33

Wer behauptet, die Germanen seien kulturlose Heiden gewesen, fälscht die Geschichte und begebt ein Verbrechen am deutschen Volke.

Hans Schemm ${ }^{134}$

In Fundamenta we see a similar intention, the argument being placed in the mouth of a Roman in the passage Römische Urteile über Germanien: two Romans discuss Germani and one of them tells of how he has observed the Germani first-hand and knows:

Incolae Germaniae non barbari sunt, ut putas. Agricolae boni sunt, deos adorant, feminas bonorant. ... Germani Romanis exemplum vitae probae et iustae praebent (FLL $\left.A^{5} I, 6\right)$.

Caesar's statement, "agri culturae non student" (BG 6.22.1), is a commonplace of ancient portrayals of barbarians, yet the refutation of these misleading presentations of the Germani stands alongside the acceptance of moral commonplaces about Germanic

132 Von See (1970), 102-105. Von Essen (1998), 21-36.

133 Führer durch die Ausstellung Lebendige Vorzeit im Lichthof der Technischen Hochschule Berlin-Charlottenburg, 15 February-15 April 1937, Leipzig 1937, cited by Lund (1995), 80.

134 Führer durch die Ausstellung Lebendige Vorzeit im Lichthof der Technischen Hochschule Berlin-Charlottenburg, cited by Lund (1995), 80-81. Hans Schemm was at the time the Kultusminister of Bavaria. He had also been the Reichsleiter of the Nationalsozialistischer Lehrerbund (Apel, Bittner (1994), 229). Apel and Bittner also refer to several articles in didactic publications of the time that rejected the appellation barbari for the Germani. Due to delays in the international interloan process it was not possible for me to obtain copies of these articles. The references are as follows: Maier, H., 'Barbarenlüge im Lesebuch', Nationalsozialistisches Bildungswesen (1937), 122-124; Gabler, K., 'Die nordischen "Barbaren” in der antiken Literatur', Die Deutsche Höhere Schule (1938), 263-267; Schäfer, K., 'Das Wort “Barbaren” im Wandel der Zeiten', Monatsschrift für höhere Schulen, 35 (1936), 261-268. 
simplicity and exemplary morality. The attempt to make the Germani into good farmers was in line with Nazi Blut-und-Boden ideology, which idealised the farmer-soldier and favoured the image of the Germanic farmer, bound to his Scholle (plot of land). ${ }^{135}$ The "Nordic" Romans, too, were supposed to have fitted this ideal in the early stages of their history. Volume II of Mader-Wecker begins with a picture of a ploughman and a passage, "De vita rustica", which states:

Horatius Romanos gentem 'rusticorum militum' appellavit, quod, nisi bellandum erat, agros strenue colentes vitam egerunt. Etiam Catonis verba memoria tenenda sunt: Vir vere Romanus semper bonus agricola bonusque colonus (Lat. Unt. MW A II, 1).

Exercitium opens with the passages, "Die Römer ein Bawernvolk" and "Die Römer ein Webrhaftes Volk". Just as in Fundamenta, the Germani, too, are presented as good farmers, and, moreover, inhabitants of a fertile land:

Germani antiqui terram fecundam incolebant... Incolae germaniae boni agricolae erant. In Germania magna copia frumenti erat (EL, 2).

Germanis agri fecundi erant (EL, 3).

The extent to which Exercitium has attempted to match its content to the requirements of National Socialist ideology is evident in the German titles of many passages. The material is supposed to be interpreted in terms of National Socialist slogans and key-words. The battle of Teutoburg Forest is a "Germanische Befreiungsschlache" (EL, 6), the destruction of the Cimbri and Teutones is described as "Germanisches Völkerschicksal" (EL, 16), and Menenius Agrippa's handling of the secession of the plebs is headed "Volksgemeinschaft?" (EL, 17). The use of the racial terminology prescribed by Eriziehung und Unterricht is also noticeable in the heading of illustrations (see appendix, figure 6).

Many features of the Germanenbild of textbooks produced under National Socialism were already long-established or had been confirmed by the Kulturkunde movement of the Weimar Republic. The new aims of education included wehrgeistige Erriehung and Rassenbewusstsein. Textbooks produced after Erziehung und Unterricht abounded in military subject matter, but so did their predecessors. The Lehrplan required that Romans, Greeks

135 See Lund (1995), 11-13, for the application of the contrast between germanisches Bauerntum and urbanised civilisation to Nazi anti-Semitic ideology. 
and Germani be presented as related 'Nordic' races. Occasionally, as in the beginning of Mader-Wecker, such ideology becomes apparent, but the use of vocabulary applicable to the National Socialist view of history only occurs in some textbooks. Some particular points of emphasis can be noted: the portrayal of Germanic farmer-soldiers (in line with Blut-und-Boden ideology) and the concomitant denial that the Germani were barbarians (they are presented instead as an Aryan Hochkultur alongside Greece and Rome). For the Lehrpläne to serve their purpose it was necessary only for the existing stereotype of the Lesebuchgermanen to be bolstered, as the Nazi Germanenbild was essentially based on the application of new slogans and the ideology of race to a clichéd Germanenbild that had already long existed. 
Despite a brief flourishing in the 1950s, Latin was widely criticised after the Second World War as a subject unsuited for educating the future citizens of a modern democracy: it was irrelevant to modern society, narrow in its content ('war and grammar'), provided material that was unsuitable or unpalatable for children and was a distraction from learning modern languages. ${ }^{136}$ Classical Humanist education came under fire for what was perceived as its moral ineffectuality - the fact that the Humanist system had been unable to prevent the barbarism of National Socialism from taking hold. ${ }^{137}$ This criticism was aimed primarily at the Humanist Gymnasien, where the classical languages were the backbone of a child's education. Although there were some attempts to modernise the teaching of Latin in the years leading up to 1970, the first step in abandoning the legacy of the Third Reich was to re-build Latin teaching on the foundations laid in the Weimar Republic. ${ }^{138}$ It was not until the 'crisis' of the ancient languages in the early 1970s that the "neue Fachdidaktik" caused a "kopernikanische Wende" in the teaching of ancient languages, part of which was a departure from the format and content of the traditional Übungsbuch. ${ }^{139}$

There was nothing new about the arguments ranged against Latin during the 1960s, though social changes and the active participation of a large number of educationists lent increased force to them. Latin was criticised as irrelevant to the modern world and to pupils' requirements as future members of the workforce and contributors to the economy. The difficulty of Latin and its role as a subject that marked out the best pupils, which had often been touted as positive qualities, came to be regarded negatively as elitism and socioeconomic selection unsuited to a democratic school system. ${ }^{140}$ The subject matter and its interpretation came under scrutiny. The heavy weight of military topics (especially in the almost inevitable reading of Caesar's Gallic War, but also in other authors, such as Livy) was much criticised. ${ }^{141}$ Certain 'ideologies' that pervaded the institution of Latin teaching were also increasingly seen as out of place, notably the idealisation of conservative Roman values. ${ }^{142}$ Amongst educationists there was a strong tendency through the 1960 s to criticise

\footnotetext{
136 Apel in: Landfester (1999), 115. Kipf (2006), 20-35 provides a thorough discussion of the position of school Latin in German society after the Second World War.

137 Schmidt (2001), 286.

138 On the return to Weimar traditions, see: Habenstein (1963), 50; Fritsch (1976), 152 ff.; Kipf (2006),

${ }^{139}$ For the term "neue Fachdidaktik", Apel in: Landfester (1999), 115. "Kopernikanische Wende" is used by Kipf (2006), $176 \mathrm{ff}$.

140 Apel in: Landfester (1999), 115-116.

141 On Livy: Kipf (2006), 158. On the predominance of military themes: Fritsch (1991), 4. On the predominance of Caesar: Fritsch: (1991), 4; Kipf (2006a).

142 Thieme (1969), 18-25. Fritsch (1991), 4.
} 
Neubumanismus and its ideal of the general education of the individual, on the grounds that it was too focused on an apolitical Innerlichkeit rather than current social and political realities. ${ }^{143}$ Georg Picht used the word 'Bildungskatastrophe' to describe what he saw as the failure of the secondary school system, the functon of which was, "den qualifirierten Nachwuchs auszubilden, der die gewaltige Maschinerie der modernen Wirtschaft und Gesellschaft in Gang balten soll.",144

A number of political changes during the period 1945-1970 were made to the detriment of Latin and Greek in schools. Probably the greatest setback was the "Düsseldorfer Abkommen" of 17 February 1955, in which the Humanist Gymnasium had its existence assured, but only insofar as it was able to compete successfully with other types of school, including Gymnasien with science or modern-language specialties. In these kinds of Gymnasium, Latin was to be available as a second or third foreign language after English, though there were moves to introduce a choice between Latin and French in Quarta. ${ }^{145}$ During the same period there was a decline in the number of hours available for Latin in school timetables. In the 1925 Richtlinien, 53 Wochenstunden were set aside for Latin as the first foreign language from year 5 onwards. ${ }^{146}$ By 1958, the figure had dropped to 44 in Hessen, 47 in BadenWürttemberg and 49 in Bavaria and North Rhine-Westphalia. In schools with Latin as second foreign language, the first four years (7-10) involved a total of 17 Wochenstunden in Bavaria in 1963, (similarly, 15 in Berlin, and 17 in Baden-Württemberg, while North RhineWestphalia had 18 and Hessen 19 in 1961). By way of comparison, Bavarian Humanist Gymnasien offered 22 Wochenstunden for the same years. It was widely recommended that four hours per week be offered in each year of the Oberstufe (years 11-13). ${ }^{147}$

Due to associations with the racist and destructive ideology of National Socialism there was a decline in the volume of scholarship on Germania produced after 1945. Dieter Timpe's introduction to the proceedings of the Kommission für die Altertumskunde Nord- und Mitteleuropas of 1986 discusses whether it is justified for such colloquia to take Tacitus' Germania as their topic. ${ }^{148}$ Mannfred Fuhrmann's article in the same publication observes

\footnotetext{
143 Kipf (2006), 25-26. For Wilhelm von Humboldt and Neubumanismus see Landfester (1999), 918-925. Becker, Kluchert (1993), 49-81.

144 Picht, G. "Zehn Thesen über die höhere Schule”, in Die Verantwortung des Geistes (1965) Olten/Freiburg im Breisgau, 85-99. This quotation, p. 92. Cited by Kipf (2006), 27. Picht recommends, furthermore, that the annual numbers of Abitur-candidates be doubled, an approach which impinged negatively on Latin and Greek as subjects that had long been considered to perform the function of selecting the most able students. Kipf (2006), 27-30.

$145 \mathrm{Kipf}$ (2006), 23.

14653 is the sum of the Wochenstunden (hours per week) for each year level from 5 to 13.

147 Kipf (2006), 30-31.

148 Timpe (1989), 7-15.
} 
that, since 1945, there was "nicht sonderlich viel über die Germania des Tacitus zu berichten". ${ }^{49}$ Whereas the 1920s and 1930s had produced three commentaries on the Germania in a short space of time, those of Fehrle (1929), Reeb (1930) and Much (1937), the only commentaries published in the years 1945-1988 were, in 1959, edited versions of Fehrle's and Much's commentaries and, in 1967, an edition of Much considerably augmented by archeological information. ${ }^{150}$ Until 1988, therefore, when Alan Lund's commentary was published, teachers had to rely on out-of-date works harking back to the time when 'Germanomania' impinged upon the work of many scholars. ${ }^{151}$

Germania remained amongst the recommended texts for the Oberstufe of Latin at the Gymnasium. Stefan Kipf's survey of important works on Latin teaching methodology used in the 1960s shows that Tacitus' Germania is recommended as a set text for the Oberstufe (years 11-13) by Krüger/Hornig (1959), Wilsing (1964), Klinz (1963) and Jäkel (1966). Notably, it is only the earliest of these (Krüger/Hornig) that recommends Germania for year 11. The difficulty of Tacitus' Latin and a generally observed decline in the quality of pupils' Latin meant that it was increasingly unlikely for Germania to be read so early. As a 1964 catalogue of the 157 school editions of all Latin authors approved for use in Bavaria shows, Tacitus is the author with the second-highest number of school editions of his works available, the first six being as follows: ${ }^{152}$

\footnotetext{
${ }^{149}$ Fuhrmann (1989), 180-184.

${ }^{150}$ Fehrle's commentary appeared in the following editions: 1929, ${ }^{21935,}{ }^{31939},{ }^{41944}$. Much's was published as follows: $1937,{ }^{2} 1959,{ }^{3} 1967$.

151 The journal Gymnasium, as late as 1952, even published a lecture given by Hans Drexler in 1944 and 1945. Drexler was one of the chief ideologues of National Socialism. See Schmidt (2001) 289-300.

152 Table copied from Kipf (2006), 147, citing data from the Amtsblatt des Bayerischen Staatsministeriums für Unterricht und Kultus 7, 1964, 124-136.
} 


\begin{tabular}{|l|l|l|}
\hline Author & $\begin{array}{l}\text { Number of approved } \\
\text { school editions in } \\
\text { circulation }\end{array}$ & $\begin{array}{l}\text { Percentage of total } \\
\text { approved editions }\end{array}$ \\
\hline Cicero & 33 & $21 \%$ \\
\hline Tacitus & 12 & $7.6 \%$ \\
\hline Caesar & 11 & $7 \%$ \\
\hline Horace & 9 & $5.7 \%$ \\
\hline Livy & 9 & $5.7 \%$ \\
\hline Sallust & 8 & $5.1 \%$ \\
\hline
\end{tabular}

Articles by Hans Martens (1962) and Hans Königer (1967) address the question of how to interpret Tacitus in school. It is clear from both articles that Germania is still a commonly read constituent of the Oberstufe-canon. Königer refers to Bavarian policy on Latin when he says, "An Schulen mit Latein als zweiter bzw. dritter Fremdsprache wird die 'Germania' in Klasse 12 oder 13 gelesen, an alt-und neusprachlichen Gymansien mit grundständigem Latein ist eine Auswabl aus dem taciteischen Gesamtwerk obligatorisch." ${ }^{, 153}$ Germania seems, therefore, in Bavaria at least, to have retained its position as one of the crowning texts of school Latin. ${ }^{154}$ Nevertheless, Königer later states, "Freilich kann Tacitus nur in Auswabl gelesen werden, selbst aus der 'Germania' wird man den allgemeinen ethnographischen Überblick (Germ. 1-27) herausgreifen. "155 Surveying the school editions of Tacitus that are in use and in print, Königer lists 15 editions of the opera minora with commentary, including 11 of Germania, along with only one of the Histories and 14 editions of selected passages from the Annals (some of which also include material from the Histories). Both Königer and Martens point out the difficulty of Tacitus' language as well as his complex handling of subject matter and mention particular difficulties involved in interpreting Germania. Martens states that Germania is usually the first of Tacitus' texts to be read in school and observes that a focus thereafter on the Batavian revolt and the campaigns of Germanicus may give a false impression of Tacitus as a "Schriftsteller von Germanenkriegen im Sinne einer Fortsetzung Cäsars unter veränderten sprachlichen Bedingungen."156 Königer makes pertinent recommendations for the interpretation of Germania in the context of "Primitivenromantik" with the concepts "Imperium - Fremdvölker" as a guiding thread. He recommends some study of the text's more recent reception history starting

153 Königer (1967), 101, citing Das Amtsblatt des Bayerischen Staatsministeriums für Unterricht und Kultus, 16 (26/08/1964), 347-350.

154 Bavaria, it should be observed, is the state that has traditionally had the highest proportion of pupils learning Latin. Riess (2005/6), 194.

155 Königer (1967), 102.

156 Martens (1962), 53. 
with Heinrich von Kleist's Hermannsschlacht as "ein frühes Beispiel chauvinistischer Befangenheit". ${ }^{157}$ It is noticeable that despite some attempts to introduce new themes and Leitgedanken to guide the interpretation of Germania, the Germani of school textbooks, though no longer dominating the scene as they had under National Socialism, generally reverted to the types familiar from the Weimar Republic and earlier. Consequently, those pupils who did not take Latin as their first foreign language would encounter little but the traditional clichéd Lebrbuchgermanen during the course of their Latin at school.

The 'first generation' of textbooks after World War II (those published up until the early 1970s) tended to display "einen restaurativen Charakter", looking back to the Weimar Republic and the spirit of the 1925 Richtlinien. ${ }^{158}$ Ludus Latinus, for example, was re-edited and reissued up until 1969. The subject matter of these textbooks generally reflects their foundation in traditions of the Weimar Republic. The textbooks studied in some detail here are the C-Version of Krüger's Lateinisches Unterrichtswerk, re-editions of Ludus Latinus, Exercitia Latina for Latin as a second foreign language, and Lingua Latina for Latin as a third foreign language. ${ }^{159}$

Textbooks of the years 1945-1970 generally display an idealised view of the ancient world similar to textbooks of the Weimar Republic and even earlier textbooks like Ostermann. The Germani are still generally to be encountered in uncritical adaptations of texts from Caesar and Tacitus. In many of the textbooks produced during this period, "werden römische Charaktereigenschaften in unreflektierter Idealisierung hervorgehoben", and traditional subject matter continues to predominate. ${ }^{160}$

The most successful coursebook of the Weimar Republic, Ludus Latinus, was revived after the Second World War. The new editions differed little from their predecessors in regard to methodology, but the content of the texts has been considerably altered, the biggest change

\footnotetext{
${ }^{157}$ Königer (1967), 105-8.

158 Habenstein (1963), 50. See also Fritsch (1978), 22. The terminology used here is that outlined by Kipf (2006), 55 n. 126, according to which the 'first generation' consists of textbooks published in the years 19451970, the second 1970-1990, and the third through the 1990s up to the 'fourth generation' from 2004.

${ }^{159}$ Krüger's textbook was published in three versions: A, for Latin as second foreign language; B, for Latin as third foreign language; $C$, for Latin as first foreign language.

${ }^{160}$ Quotation by: Kipf (2006), 77. Kipf notes that of the single sentences provided in Bornemann's Lateinisches Unterrichtswerk, approximately one third are on the topic of war. Bornemann's stated attempt to draw more passages from “dem 'bürgerlichen' Leben und der Umwelt des Schülers” (Lat. Unt. Bornemann, teaching materials, 2) manifests itself in passages on rural life and family life, though, as Kipf points out such sentences as "Paulus cum Ernesto et Friderico equum aegrotum visitat" are not likely to have been genuinely engaging.
} 
being the excision of much German and Germanic subject matter and the revision of that which remains. ${ }^{161}$

Ludus Latinus I B of 1963 opens, as the 1932 edition had, with a paragraph headed Zur Vorbereitung. ${ }^{162}$ Whereas the earlier version had welcomed pupils with a short narrative about the first day at school as a Sextaner, punctuating the text with Latin vocabulary used at school and quoting Paulus, the ubiquitous Lateinbuch schoolboy, the newer Ludus Latinus restricts itself to observations on the Latin origins of many German words, as in the sentence, "Paul studiert an der Universität Köln Medezinn". The modern school has moved away from being the 'Latin country' of earlier times, and rather than taking for granted that Latin is an integral part of the world of school and one's education in general, the new textbooks often include "Legitimationsstücke" that justify Latin by reference to its usefulness or its superior qualities as a means of mental training. ${ }^{163}$

As in earlier editions, the Germani make their appearance before the Romans, who are first mentioned in the sentence, "Romani saepe cum Germanis bellabant", one of the sentences preceding the passage Die Römer im Kriege in chapter 10, the subject matter of which has changed little since Die Römer in the 1932 edition. The Germani, however, are introduced in a different manner. Whereas Ludus Latinus of 1932 had repeatedly described the hunting of wild animals in the forests (and accompanied the descriptions with illustrations - see figures 2 and 4 in the appendix), the new version includes a couple of comments about hunting within a description of the Germani in their environment (in Von den Germanen I, chapter 9, and II, chapter 11). Both chapters are presented as the words of Paulus, a keen Sextaner who knows about Tacitus. There are no poets praising the fatherland this time. The Germani instead display a rather modern sensibility in their appreciation of the landscape: "Caelum Germaniae serenum non erat. Sed Germani naturam patriae amabant. Silvae Germaniae magnae et densae erant, campi lati” (LL $I^{11} B$, 4). These seem to be a deliberately naïve twist on Tacitus' statement, "quis porro, praeter periculum horridi et ignoti maris, Asia aut Africa aut Italia relicta Germaniam peteret, informem terris, asperam caelo, tristem cultu aspectuque nisi si

161 By way of contrast it is interesting to note the contents of a publication for British and Commonwealth 'O' level pupils which abounds in British content of all historical periods. Experientia (1957) includes passages on Britannia, Britain and England adapted from such authors as Caesar, Tacitus and Erasmus, and even presents recent history in a classical light. Especially notable for its patriotism and liberal application of the word 'Britann' are the passages on the ascent of Mount Everest: "Cum Anglorum regina Elizabeth thronum primo ascenderet, nuntius allatus est montem Everest a Britannis conscensum esse... Et passi sunt et montem superaverunt Britanni illi qui, duce Ioanne Hunt, ex Tamesi flumine profecti, primum in urbem Catamandianam se contulerunt... Primi, deficientibus viribus, mille passus uno impetu ascendere non possunt et redire coguntur. Nunc succendunt alii, Butbia Tensing et Edmundus Hillary. Oxygenio praediti, vexilla cum Cruce ex prioribus excipiunt et stationem ponunt... [S]tatuta est firmiter iam Christi Crux in vertice orbis terrarum et vexilla patria vento panduntur" (Experientia, 15, 18).

162 In this instance, "B" means the Bavarian version.

163 Stray (2007), 6. 
patria sit?" (Germ. 2.2). The effect of the passage in Germania is to emphasise not Germanic Heimatliebe but rather the unattractiveness of the land for immigration, the insistent parallelism of the tricolon creating a sense of finality; Germania is informis, aspera and tristis and that is that.

The Germani, in these passages, are farmers, hunters and gatherers. One aspect of the less emotive tone in passages about the Germani is the avoidance of confusion between ancient Germania and modern Germany in the 1963 Ludus Latinus. Instead of a passage titled Arminius, der Befreier Deutschlands, we have Freiheitsliebe der Germanen. ${ }^{164}$ The new pictures of the Germani are less wild-looking than those of 1926 and 1932. There is an illustration accompanying the text "Fürsten und Gefolge" showing cavalry saluting their chief. The infantry in the background are arranged in an orderly fashion, and although the traditional warlike representation of the Germani continues, the impression is less barbaric than in some earlier portrayals (see appendix, figure 7).

The $13^{\text {th }}$ edition of Ludus Latinus II A from 1969 includes none of the 54 pictures that had been included in the $10^{\text {th }}$ edition of 1934. The pictures had been an important feature in the presentation of the series Ludus Latinus and in making the book attractive to young pupils. There has been no reduction in the grammatical material covered and little alteration to the order in which it is introduced. The most significant alteration to the text is the replacement of seven passages about the Germani, summarised in the table below.

\begin{tabular}{|c|c|}
\hline Ludus Latinus II $A^{10} 1934$ & Ludus Latinus II $A^{13} 1969$ \\
\hline 1. Die erste Quintastunde & 1. Die erste Quintastunde \\
\hline 2. Die alten Germanen & 2. Von dem Hunde \\
\hline 3. Ein germanisches Volksthing & 3. Ehrfurcht vor dem Alter \\
\hline 4. Germanicus auf dem Teutoburger Schlachtfelde & 4. Gerechtigkeitsliebe bei einem ganzen Volk \\
\hline $\begin{array}{l}\text { 5. Die römischen Rheinstädte und der römisch- } \\
\text { germanische Grenzwall }\end{array}$ & $\begin{array}{l}\text { 5. Die römischen Rheinstädte und der römisch- } \\
\text { germanische Gren₹wall }\end{array}$ \\
\hline $\begin{array}{l}\text { 6. Die Römer als Kaufleute und Lehrmeister der } \\
\text { Germanen }\end{array}$ & $\begin{array}{l}\text { 6. Die Römer als Kaufleute und Lebrmeister der } \\
\text { Germanen }\end{array}$ \\
\hline 7. Die Saalburg & 7. Die Saalburg \\
\hline 8. Der kimbrische Schrecken & 8. Marius vernichtet die Teutonen \\
\hline
\end{tabular}

${ }^{164}$ It is uncertain whether the saying, "Tempora mutantur, nos et mutamur in illis", which follows the text "Die Germanen: Fürsten und Gefolge" is intended to encourage observations on the foreignness of the ancient Germanic warrior ethic. Many of the texts are followed by choice quotations and sayings, some of which clearly have some relevance to the topic of the text, others of which are wholly unrelated. 


\begin{tabular}{|l|l|}
\hline 9. Die Schlacht bei Vercellä & 9. Der Untergang der Kimbern \\
\hline 10. König Alarich vor Rom & 10. Von der Gründung Roms \\
\hline 11. Alarichs Ende & 11. Der Raub der Sabinerinnen \\
\hline 12. Dietrich von Bern & 12. Die letzten drei römischen Könige \\
\hline 13. Der Ostgoten Todeskampf am Vesuv & 13. Tib. Gracchus, der Volksfreund \\
\hline
\end{tabular}

The texts of chapters 2, 3 and 4 now provide exempla of particular moral qualities: fides in the case of the dog, respect for age in chapter 3 and the probitas of the Athenian citizen body in chapter 4. Chapters 10-12 include stories from early Rome, which, despite their often violent or even grisly content, seem to have been widely considered subject matter well suited for children. ${ }^{165}$ The 'Germanic' (Gothic) invasions which toppled the Roman empire have been removed.

The passage Die römischen Rheinstädte und der römisch-germanische Gren₹wall remains almost the same. Die Römer als Kaufleute und Lebrmeister der Germanen is unchanged. Passage 8 of the 1934 Ludus Latinus II reads, "Iam secundo a. Chr. n. saeculo Germani Romanos perterruerant”. This sentence has been excised in the 1969 edition. The gleeful description of the Roman garrison's destruction at the hands of the Germani has been removed from the Saalburg passage, with its emotive reference to the success of "maiores nostr".

Sed iam pridem cohors illa discessit. Non iam milites Romani iis Germanis obstant, qui ad castra accedunt. Nam a maioribus nostris devicti et propulsati sunt illudque castellum, quo supra descripsimus, circumventum, expugnatum, inflammatum est $\left(L L A^{10} I I, 8\right)$.

Sed iam pridem illa cohors discessit. Castellum inflammatum et deletum est" (LL A $\left.{ }^{13} I I, 6\right)$.

The titles of passages 8 and 9 have been changed so as to shift the emphasis from the terror inflicted by the Germani on the Romans to the failure of the Cimbri and Teutones. The theme of furor Teutonicus, which had pervaded almost all of chapters 2 to 13 in 1934 is understated almost to the point of exclusion in the 1969 edition.

The passages that remain practically untouched, chapters 5 and 6 , give a positive interpretation of romanisation that continues to fit with traditional justifications for

165 Anecdotes from early Rome are staple Lehrbuch-texts, numerous passages occurring in all the textbooks here analysed starting with Ostermann of 1872. See Lat. Unt. Krüger (1967), iii (foreword of 1955) for the opinion that these stories are particularly suited to young beginners. 
teaching Latin as a language of culture and civilisation, and a key to understanding the roots of much of European culture ( $\left.L L A^{10} I I, 8 ; L L A^{13} I I, 6\right)$.

From the passages of German for translation into Latin, Wodan, Siegfrieds Kampf mit Brunbild, Hildebrand und Hadubrand and Die Raubritter have been removed, leaving Der Rattenfänger von Hameln as the only German or Germanic topic for translation. The fairytale of the Pied Piper is allowed to remain while the Germanic myth and history of the other passages is no longer considered suitable.

Ludus Latinus part III had, in 1932, only included one section about Germania. In the seventh edition of 1966 the passages Die Schlacht im Teutoburger Wald and Soldatentod have been removed, along with a number of other war stories. The following table lists the changes made, illustrating the general move away from warlike subject matter. As in Ludus Latinus II discussed above, Humanist commonplaces are favoured topics of the new passages. 


\begin{tabular}{|l|l|}
\hline Passage in LL III (1932) and source on & Passage in LL A III (1966) \\
which it is based & \\
\hline $\begin{array}{l}\text { Der Opfertod des Königs Kodrus (from Val. Max. } \\
5.6 .1 \text { ) }\end{array}$ & Der Raub der Helena \\
\hline $\begin{array}{l}\text { Spartanische Tapferkeit (Cic. Fin. 2.97; Tusc. } \\
\text { 1.101) }\end{array}$ & Mit wenigem zufrieden sein \\
\hline Horatius Cocles rettet Rom (Liv. 2.10) & Flötenspieler in Rom \\
\hline $\begin{array}{l}\text { Die Auswanderung der Plebs auf den heiligen Berg } \\
\text { (Liv. 2.32-33) }\end{array}$ & Tarquinius S. läßt das Delphische Orakel befragen \\
\hline $\begin{array}{l}\text { Die römischen Gefangenen nach der Scblacht von } \\
\text { Cannä (Cic. Off. 3.113; Gell. 6.18) }\end{array}$ & Dicbter und Staatsmänner besuchen sich \\
\hline $\begin{array}{l}\text { Die Scblacht im Teutoburger Wald (Vell. 2.117; } \\
\text { Florus 2.30), Soldatentod (Inscription on }\end{array}$ & Cicero über wahre Güter \\
gravestone of Marcus Caelius) & \\
\hline
\end{tabular}

Max Krüger's Lateinisches Unterrichtswerk was widely used throughout the 1950s and 1960s, especially in Berlin, where Krüger worked in the Pädagogische Hochschule of the Free University. ${ }^{166}$ It is representative of the traditional style of Übungsbuch and its subject matter involves to a great extent stories from early Roman history sourced from Livy's first decade. Anecdotes from ancient history, myth, philosophy and literature perform an exemplary function and early republican Roman values are idealised. Klaus-Dieter Thieme criticised Krüger's Unterrichtswerk for its ideology, which he saw as an outdated attempt to instill the norms of patriarchal society and "einer frübbürgerlich-kapitalistischen Arbeits-und Leistungsgesellschaft' ${ }^{167}$

Lat. Unt. Krüger C I (1967) contains no passages on the Germani, though they appear in the most 'traditional' of guises in some practice sentences, for example, “Antiquis temporibus Germani genus ferum fuerunt. Romani, cum Germanos primos vidissent, magnitudine corporum territi sunt. Eisdem hominibus opera iucunda non erant” (Lat. Unt. Krüger $\left.\mathrm{C}^{7} \mathrm{I}, 34\right)$. In volume two there is only one text about the Germani, "De Germanis antiquis", which is largely preoccupied with Germanic weaponry and warfare as related by Tacitus and Caesar, who are credited as the text's sources. Overall, the Germani are of little importance in Krüger's textbooks.

166 Fritsch (1976), 152-155. Henceforth the various versions of the textbook will be referred to as Lat. Unt. Krüger $A, B$ and $C$.

167 Thieme (1969), 24. The versions which Thieme criticises are: Meurer, H. et al. ed.; Krüger, M.; Übungsbuch A ${ }^{6} \mathrm{I}$ (Zweite Fremdsprache) and A ${ }^{6} \mathrm{II}$, Frankfurt a.M./Berlin/Bonn/Munich, 1967. 
Latin as a third foreign language was taken only by a small number of students. Lingua Latina, a textbook for this shortened, compressed form of school Latin, beginning in year 11, takes the same approach as a number of older textbooks that had sought to compress and focus the content on the 'essentials', in that there is a heavy emphasis on Caesar. ${ }^{168}$ As a result, Roman wars with barbarians (Gauls and Germani) make up a significant proportion of the subject matter. The Romans do not, in fact, appear in any context other than their encounters with Gauls and Germani until lesson eleven of the morphology section, ${ }^{169}$ which contains 47 lessons, including 40 passages and inscriptions. Ten of these are on the subject of Germania or the Germani, mostly fairly bald adaptations of Caesar or Tacitus. After a few introductory Einzelsätze including a selection of the sort of moral commonplaces that occur throughout many textbooks of the period ("1. Vita vigilia est... 5. Non scholae sed vitae discimus... 8. Incolae Germaniae patriam diligunt'), our first text is Die alten Germanen, in which the Germani make their appearance as fearsome inhabitants of a tough country:

\section{"Incolae Asiae vel Africae vel Italiae Germaniam non petunt; metuunt enim silvas terrae et ferociam incolarum. Incolae Germaniae in pugna hastas gerunt. Galeis se non tegunt. Litteras incolae Germaniae neglegunt. Agriculturam saepe curae feminarum committunt" (Lingua Latina, 11).}

The passage Sueben und Ubier presents a similarly unreflective Germanenbild. In Gallic War the Suebi, and particularly their leader Ariovistus, are presented as the worst sort of barbarians: rapacious, untrustworthy and wild. The negative tone is absent from the description in Lingua Latina.

Privatus ac separatus ager apud Suebos non est neque diu colunt agros uno in loco. Vita Sueborum libera est. A pueris sunt durati. Itaque viri excelsa statura sunt (Lingua Latina, 14).

The Germani in Lingua Latina are used as a 'familiar' point of reference for the first two lessons, after which they feature in a variety of historical situations. They are presented simply as wild but impressive. They are definitively barbarian, playing a role that fits into

168 The edition here examined is the third (1950). Compare the comments in the introduction to the condensed, revised version of Fundamenta Linguae Latinae and the introduction to Exercitium Latinum, which was intended for schools with only one-and-a-half to two years of grammatical instruction (see chapter 3 ).

169 Lingua Latina is structured like many traditional Übungsbücher, with a morphology/grammar section (Formenlehre) followed by a syntax section (Satzlehre). 
the focus on Caesar's Gallic war and other encounters between Romans, Gauls and Germani. Some additional Germanic subject matter includes one of the extra passages in the grammar (Formenlehre) section based on Iordanes (Getica, 29) about Alaric's burial under the river Busento. The syntax section (which follows the grammar section) has 22 lessons including further episodes from Caesar, but nothing on the Germani. ${ }^{170}$

Because Germanic antiquity, most of all Germania, became an undesirable topic in the wake of its misuse under National Socialism, schools often avoided Germania as a set text and the authors and editors of textbooks often excluded Germanic material. This should be understood as a significant change to subject matter in the context of the largely conservative textbook production of the years 1945-1970. While postwar textbooks were largely based on those produced under the Weimar Republic, Kulturkunde had been abandoned and large quantities of Germanic and German subject matter were no longer considered justifiable. Only in the re-issued Ludus Latinus and some less commonly used texts like Lingua Latina were the Germani any longer used as a first point of identification for pupils who were being introduced to the ancient world. In Ludus Latinus there are also signs of the re-working of passages so as to avoid emotive patriotic appeals to the reader in connexion with the Germani. The general lack of development in textbook methodology and the lull in academic interest in Germania precluded a fresh approach to the Germani or Germania Romana as topics of school texts. What we find, therefore, are the traditional 'Lebrbuchgermanen', now half ignored. It was not until the "kopernikanische Wende" that resulted from the 'crisis' of classical languages in schools in the early 1970s that new textbooks began to take a different approach to these topics.

170 There is a passage on the Nervii, who, according to Tacitus (Germ. 28.4), claim Germanic ancestry. 
This last chapter deals with textbooks published after 1970. These new 'generations' of textbooks clearly attempt to counter the various arguments made by opponents of Latin in schools. There is an unprecedented emphasis on subject matter, both as a motivating influence for pupils and as a vital ingredient in educating children about a language and culture far removed from their own. ${ }^{171}$ An important step in justifying Latin teaching in the contemporary political and educational climate, the Lernzielmatrix produced by Klaus Westfalen and Otto Schönberger for the Deutscher Altphilologenverband in 1971 provides the framework for thematic material in the instruction of Latin, and its categories are reflected in Lehrplänen. ${ }^{172}$ The key-word Multivalenz is an important feature of this model, specifying the role of Latin as a subject that teaches more than linguistic skills. Regarding the way in which the Germani are portrayed, the rubrics 'society, state and history' and 'essential questions of human existence' provide the thematic framework, and textbooks increasingly present material and pose questions in such a way as to encourage transfer and application of concepts and knowledge to modern societal questions and problems. From the mid1980s there has been a resurgence of interest in the Germani and we see an unprecedented variety of approaches to using both Germania libera and Germania Romana as a subject for Latin passages and German informational texts. It is from the 1980s onwards that the most significant changes in the Germanenbild of textbooks take place. Features of a traditional Germanenbild which remained fairly constant up to this time are in most cases drastically revised and re-interpreted, and the nature of Roman historical and ethnographic sources is called into question.

Stefan Kipfs survey of 18 Lehrpläne for the upper level (Sekundarstufe II) of secondary school Latin from across Germany between 1973 and 2003 is the most useful guide in the absence of reliable empirical analysis about the texts chosen for reading at this level. All of the Lehrpläne investigated included the traditional canonical authors Caesar, Cicero, Horace, Livy, Ovid, Sallust, Seneca, Virgil as well as Tacitus. These are among 163 authors who are named at least once. Lehrpläne recommend readings arranged by author, genre and theme, though thematic recommendations predominate. ${ }^{173}$ Many of the themes show an attempt

${ }^{171}$ Fritsch (1991), 4-22. Kipf (2006), 271-280.

172 Kipf (2006), 201-214, 273; Fritsch (1991), 5-6. Glücklich (1978), 197-203. The Lernqielmatrix divides subject matter into four thematic groups: 1, language; 2, literature; 3, society, state and history; 4, essential questions of human existence (Humanism). Each of these subject areas is to be learnt and understood in four stages: 1 , knowledge; 2 , reorganisation of knowledge; 3 , transfer; 4 , problem-solving.

173 Kipf (2006), 384-388. 
to relate readings to current social questions. Topics relevant to Germania include, for example: "Rom und fremde Völker" and "Romidee: Ideologie und Kritik" from BadenWürttemberg (1994), 181; “Wir und die Fremden - ein Grundproblem gesellschaftlichen Zusammenlebens im Spiegel antiker und moderner Texte" from North-Rhine Westphalia (1999), 26 and "Darstellungen fremder Völker bei römischen Autoren" from Berlin (2006), 17. ${ }^{174}$

In the absence of thorough empirical evidence on the use of Germania as a school text I shall make some anecdotal observations, the limitations of which are obvious, but which are nevertheless representative of some aspects of the text's treatment in schools. Reports on school projects in Auxilia (1989) and Der altsprachliche Unterricht (1999) show Tacitus' Germania being read in year 11 at Humanist Gymnasien. ${ }^{175}$ Eller (1987) recommends exceptionally - Germania along with the Gallic War, the History of the Franks by Gregory of Tours, Velleius' Roman History and other texts as part of a Germani topic for year 10 students reading original Latin for the first time. ${ }^{176}$ The text remains, however, unpopular with many teachers for its associations with Germanomania, and Schulz (1995) introduces an article on the work's interpretation as a whole with this observation and expresses the hope that access to new research and new interpretative approaches will revive its popularity. ${ }^{177}$ An attempted enquiry into the teaching of Germania at Berlin schools around the beginning of the 2007-2008 school year was largely fruitless in terms of finding teachers who were teaching or had taught Germania, though by any empirical standards my sample is unrepresentative because of the low proportion of enquiries that elicited a response. One Humanist Gymnasium where Latin is taught from year 5 (Gymnasium zum grauen Kloster) informed me that Germania had not been taught there for the last 18 years. None of the teachers from other schools who expressed an interest in teaching Germania taught it regularly, citing a lack of available teaching hours which often left pupils unable to deal with the difficulty of Tacitus' Latin and which necessitated concentration on specifically Roman topics. ${ }^{178}$ In several instances ethnographic passages in Caesar's Gallic War were mentioned as a linguistically more manageable alternative to Tacitus. Several teachers

\footnotetext{
${ }^{174} \operatorname{Kipf}(2006), 390-391$.

175 Maier (1989b), 114-130; Rosenberger (1999), 51-54.

176 Eller (1987), 315.

177 Schulz (1995), 21.

178 The general tendency towards reduction in teaching hours for Latin continued in the period 1974-2000, as shown by Kipf (2006), 223-4: in North Rhine-Westphalia the sum of 34 Wochenstunden for L1 in years 5-10 in 1974 fell to 25 by the year 2000; in Bavaria the sum fell from 30 to 26; in Berlin from 28 to 26; in Hesse from 30 to 24 and in Lower Saxony from 27 to 22. The hours allotted to Latin as a second language were also reduced over the same period: in Bavaria from 17 to 15; from 16 to 14 in Berlin; from 18 to 15 in Hesse and from 19 to 16 in Lower Saxony.
} 
mentioned the liberal use of translations. Nevertheless, as Schulz states in 1995, it is still in schools that Germania is most often read. ${ }^{179}$

The lack of academic attention paid to Germania after the Second World War combined with the lag that usually exists between academic progress and the updating of school materials meant that it took some time for schools to have the option of using materials that were not based on work done during the 1930s. A new translation of Germania by Manfred Fuhrmann was published in 1971, offering an alternative to that of Büchner. ${ }^{180}$ Büchner's translations of the Tacitean opera minora had first appeared in 1955. A second edition was produced in 1963 and a third, with updated commentary, in 1985. Büchner's introduction, however, which was based on a 1943 lecture originally released as a military letter, presented an outdated interpretation based on the idea that, "Jede Würdigung der Germania muß davon ausgehen, daß die Germanen in erster Linie mit Liebe und Bewunderung dargestellt werden". In this light, Büchner asseses Germania as a factual essay on the moral qualities of the Germani, of whom he claims, "Ihr ganzes Lebensinhalt ist das Streben nach virtus."181

$[F]$ rei von Wertsetzungen, die den Blick für das Echte trüben, wie Reichtum, äußerem Glan₹. und äußerer Scbönheit, folgen sie allein dem im Göttlichen begründeten honestum als der Richtsschnur ihres Handelns, und diese Bindung ist bei äußerer Freibeit doch stärker als selbst der Tod. ${ }^{182}$

The influence of this kind of interpretation is noticeable in Gerhard Eller's 1987 article in which the recommendations for teaching Germania 1-27 revolve around identifying Germanic qualities which Eller considers Tacitus to have observed 'correctly'. There is a distinct impression that some of the characteristics, such as "Innerlichkeit" and "innere, seelische Werte, die für den Germanen Bedeutung haben und von denen er sein ganzes Handeln... leiten läßt' are deutsch as much as they are germanisch, and some of the 'facts' identified are not facts (for example, "die Tatsache, daß Germanen... auf den Besitz, von Edelmetallen keinen Wert legen"). ${ }^{183}$ The concentration on chapters 1-27 of Germania, which has traditionally been prevalent in schools, is due not only to the overwhelming number of obscure tribal names

\footnotetext{
${ }^{179}$ Schulz (1995), 21.

180 The references to Fuhrmann's translation in this essay are to a 1977 reprint.

181 Städele, (1997), 525. Büchner (1985), 132, 131.

182 Büchner (1985), 131.

183 Eller (1987), 313, based especially on Tac. Germ. 5. The discovery of valuable Roman metal and glass vessels in Germanic tombs indicates that possession of such items, restricted to an upper class, was a mark of status. In addition, Roman coins were widely used by the Germani, not only near the border as Jahnkuhn (1971), 144, describes, but also amongst tribes further from the Roman empire (the "interiores" of Tac. Germ. 5). See Lund (1988), 127-129; Lund (1991), 1884-1888; Rives (1999), 133-135.
} 
in the second half of the text, but also to the past tendency to search for facts, particularly those which could be applied to the Germani, or Germans, in general. ${ }^{184}$

Allan Lund's important Germania commentary in 1988 created a new basis for further academic work on Germania and, for researchers and schools alike, provided a thoroughgoing alternative to Rudolf Much's work. ${ }^{185}$ Lund focuses particularly on Germania as literature and presents Tacitus' ethnography in the context of the ancient ethnographic tradition, clearly identifying topoi and literary concerns behind Tacitus' text which must be considered before its value as a historical source can be assessed. Since Jahnkuhn's contributions to the third edition of Much (1967) there have been no updated commentaries in German which systematially compare Tacitus' text with the archaeological record as Rives (1999) has done in English. Archaeology is the best source of new knowledge about the Germani and Germania, and since the 1950s the dominance of Roman military archaeology has given way to an increased focus on the archaeology of non-military settlements. ${ }^{186}$ Archaeology has tended to show, and archaeologists have paid increased attention to, signs of co-operation between Germani and Romans. ${ }^{187}$ A large number of recent exhibitions in German museums have been centred on the idea of cooperation and intercultural exchange. ${ }^{188}$ Since the 1980 s there has been renewed publication of school materials on Germania. A whole volume of the series Auxilia (volume 20,1989) was devoted to Germania as a school text, and numerous articles have appeared in didactic publications. ${ }^{189}$ While a number of old school editions continued to be published, new commentaries published by Städele (1983), Haug (1987) and Schulz (1995) provided new interpretative angles and greater reference to archaeological finds.

\footnotetext{
${ }^{184}$ Rosenberger (1999), 51, mentions the problem of copious obscure tribal names in the introduction to his school project report.

185 Lund's work is an academic commentary.

186 Bechert (2003), 76.

187 Bechert (2003), 140-142, 144-147, discusses research into the modern concepts of 'integration' and 'romanisation', the concepts of natio and romanitas, and the role of the military in transmitting Roman culture and civilisation.

188 The Landesmuseum Mainz. presented 'Die Römer und ihr Erbe, Fortschritt durch Innovation und Integration' from 2 February until 25 May 2003, see Klein (2003). The Rheinisches Landesmuseum Bonn presented 'Krieg und Frieden, Kelten - Römer - Germanen' from 26 July 2007 until 6 January 2008.

189 Eller (1987), 310-318; Maier ed. (1989); Städele (1990), 156-168; Städele (1993), 106-124; Rosenberger (1999), 51-54. The journal Der altsprachliche Unterricht has published many articles on ancient and modern ethnography which have kept the didactic literature up to date with modern research, such as: TrzaskaRichter, C., 'Das römische Germanenbild und wie man es benutzte' (1993); Lund, 'Die Erfindung der Germanen' (1995a), ‘Caesar als Ethnograph’ (1996), Siebenborn, 'Barbaren, Naturvölker, edle Wilde’ (1998), 'Antike ethnologische Vorstellungen in der Entdeckungsliteratur' (1998a).
} 
Of the 14 new textbooks published in the years 1970-1979, only one, Roma, was conceived exclusively for use in the L1 form of school Latin. ${ }^{190}$ Taking Latin as first foreign language had became the exception and was no longer the defining form of instruction. Latin as the second foreign language became the "eigentlich [e] Bastion des altsprachlichen Unterrichts". ${ }^{191}$ It is worthwhile to examine the content of Roma, as it necessarily contains more material than other new textbooks and was used by pupils for whom Latin was a dominant component of their education.

The introduction to Roma sets out its approach as an attempt,

den Unterricht in Latein als erster Fremdsprache zeitgemäß zu gestalten. Insbesondere sollen die zusammenbängenden Lesestücke inhaltlich ansprechen und einen systematischen Überblick über antikes Denken und Handeln aufbauen. Die mehrfarbige Bebilderung will nicht nur den Text unterstützen, sondern soll auch Freude am Umgang mit Latein vermitteln (Roma $\left.I^{2} \mathrm{~A}, 3\right)$.

The same intentions are behind almost all new Lateinbücher published from this time onward. The book uses Identifikationsfiguren (central characters with whom students are supposed to identify), though in a less comprehensive fashion than many later texts, by describing the daily life of two Roman children, Marcus and Claudia, and including a Roman boy, Titus, in a number of stories.

The Romans are often presented in a conservative fashion involving idealisation of the mos maiorum, and its patriarchal structure. An example is the chapter "Die Mächtigen in Rom".

Facta maiorum excitabant puerorum admirationem... Non solum pueri, sed etiam virgines facta maiorum memoria tenent (Roma $\left.I^{2} \mathrm{~A}, 90\right)$.

Saepe gravitas oris dignitatem et auctoritatem senatorum indicabat (Roma $\left.I^{2} \mathrm{~A}, 92\right)$.

Germania and the Germani appear relatively frequently in Roma I, less frequently in volumes II and III and not at all in volume IV, which suggests that the use of Germania as a relatively familiar setting influences the construction of this course. The text "Männer

${ }^{190}$ Latin taken as first, second, third or fourth foreign language respectively is often referred to as L1, L2, L3 or L4.

191 The words are those of Westphalen (1981), 58, cited by Kipf (2006), 281. See Kipf (2006), 281-285. The course Redde Rationem was produced for L1 and L2 use. 
politisieren" (chapter 26) is a dialogue between some Romans and a Germanus in which (by way of providing practice with possessive adjectives), each expresses his feelings about his respective homeland. Tacitus' words at Germania 2.2 have been adapted so as to shift the emphasis to patriotic sentiment.

\section{G: Mea patria non tam pulchra est quam Italia, Romani. Caelum nostrum est asperum, crebri venti plantis nocent. Bestiae malae in nostris silvis nigris ${ }^{192}$ se occultant... . \\ R: Natura Germanis divitias soli negat. Tamen vestram terram valde amatis. \\ G: Quis suam terram non amabit? - Quia patriam nostram amabamus, nostri interdum cum vestris copiis pugnabant (Roma $\left.I^{2} \mathrm{~A}, 58\right)$.}

In the third volume of Roma, amongst the revision material, there is a passage based on chapters 1-2 and 5 of Germania. The sentences are all closely based on Tacitus except for one: "Germanis autem nibil carius bac terra, quia patria est" (Roma III ${ }^{1} A$, 126). This sentiment amounts to something of a topos in traditional Latin Übungsbücher and an example of the ways in which traditional subject matter has influenced Roma. ${ }^{193}$ The word patria, which occurs only twice in Germania (at 2.2 and 31.2) and cannot be considered a major theme of the text, is a common feature of textbook passges De Germania or De Germanis. When "Germania" and "Deutschland", "Germani" and "Deutsche" were used synonymously, the use of patria to refer to Germania and contemporary Germany was clear enough. The avowed patriotism of the Germani was thus intended as a model for the pupils to follow. Even in Roma, however, patria is used in a way which implies the existence of a single ancient patria of the Germani, which is no more than a modern fantasy. Such use of patria has little to do with ancient notions of a homeland, which, for the Germanic tribes of antiquity, would have been more local than what was signified by the Roman exonym Germania. ${ }^{194}$ In Roma, as in most traditional textbooks, 'patria' is to be understood as Germany, the pupils' fatherland - an echo of the old conflation of Germania and Deutschland.

\footnotetext{
192 Neither Caesar nor Tacitus describes the forests of Germany as 'black'. The word is included here perhaps because it is idiomatic in German.

193 An early instance of this sentiment appears in 1896: "In Germanis magnus amor patriae et libertatis erat" (Lat. Unt. Ost.-M., 15). See chapter 2 for $L L I^{1}$, 6. An exhortation to Quinta pupils to be of service to their patria occurs at $L L{ }^{10} I I$. 1-2. See chapter 3 for: Lat. Unt. MW I A, 3; FLL A I , 5. For a revised approach after World War II featuring the Germani as patriotic nature-lovers, see chapter 4: LL I $B^{11}$, 6-7. It ought to be kept in mind that amor patriae features prominently as a defining Roman virtue in textbooks of all periods. See chapter 1 for Ostermann-Müller (13), a description of Roman patriotism representative of traditional Übungsbücher.

${ }^{194}$ A relevant passage of Germania is at 10.6, where the adjective patrius refers to weapons from the respective patriae of two champions whose combat is intended to predict the outcome of an impending war between their tribes. The meaning of patrius is clearly specific to each tribe rather than being 'pan-Germanic'.
} 
Chapters 26 and 27 of volume I deal with the ancient theme of discordia as the bane of the Germani. ${ }^{195}$ "Germanische Zwietrache" (chapter 27) uses the encounter of Flavus and Arminius across the river Weser (Tac. Ann. 2.9-10) as its basis and presents a simple version of the brothers' arguments in dialogue form. It is summed up by the Roman from the previous chapter: "Clarum exemplum discordiae narras. Quis vitia vestra sanabit?" (Roma I ${ }^{2} A$, $60)$.

The Germani next feature in chapter 32, where the boy Titus marvels at the view of Rome from the Capitol. Suddenly he is struck with concern that Rome's greatness could be transient: "Ego interdum in metu sum propter Germanos. Nam pater de tumultu Germanorum narrabat. Instatne nos periculum?' (Roma $I^{2} A$, 70) Uncle Publius assures the young Titus that discordia amongst the barbarians will be to the Romans' advantage and that Roman armies will always be strong enough to ward off their enemies. The fall of Rome is a relatively uncommon topic for textbook passages and although there are hints at the catastrophic Gothic invasions of the fourth and fifth centuries, the passage is still set during the early empire.

In chapter 33 Titus continues to marvel at "Bauleistungen in Rom", which leads into chapter 34 with the dialogue "Römische Bauleistungen in den Provinzen". The Romans' conquests in Gaul and Germania are presented as civilising processes, evidenced by the Romans' engineering and city-building achievements. "Olim exercitus Romanus multa Gallorum oppida expugnavit. Postea nostri oppida magna aedificaverunt" (Roma $I^{2} A$, 74). Titus asks Publius about the Romans' failure to conquer "totam Germaniam". Publius mentions the effectiveness of Germanic guerilla warfare but does not describe any individual battles, even that in the Teutoburg Forest.

Although Roma represents a new generation of textbooks in terms of its methodology, much of the subject matter remains rooted in the traditions of Latin textbooks, which can fairly be described in some instances as topoi. Some of these topoi are clearly in evidence in passages relating to the Germani.

195 The classic reference to Germanic discord is Tacitus' gleeful description of the massacre of 60,000 Bructeri by their Germanic neighbours (Ger. 33). Tiberius' policy of allowing Germanic disunity, rather than Roman offensives, to weaken Rome's enemies east of the Rhine was successful (Tac. Ann. 2.26). 
During the 1980s there were only 5 new school Latin courses published in Germany alongside numerous new editions of older post-war publications. ${ }^{196}$ Ostia was first published in 1985 and offers a new degree of lavish illustration and colourful presentation. Its chapters cover a very broad range of topics about the ancient world. Only one, however, includes material on the Germani. A lengthy text in German describes Romano-Germanic encounters and comments on the biases inherent in the Gallic War and Germania. This is important for putting into perspective the humorous passage "Die Germanen: kräftige Sklaven, Bernstein, Raube Sitten", in which Roman parents tell their children stories about wild Germanic customs that are at first attractive (when the children hear that the Germani have no school) and then repellant - when they hear that Germanic fathers may gamble away their children's freedom, or that the Germani bathe in frigid water (Ostia $\left.{ }^{1} I, 100-103\right)$. The teachers' handbook compares the "Klischeevorstellungen" and occasional "naiv [e] Bewunderung" behind Tacitus' ethnography with the lack of understanding shown by Europeans in early encounters with indigenous peoples of Africa, America and Australia (Ostia, Lebrerkommentar, 81). The brief inclusion of the Germani in Ostia therefore takes an approach based on productive scepticism towards ancient source material and its prejudices, which leads to the application of critical thinking to other instances of intercultural misunderstanding. Such themes are to become common in later textbooks which pay even more attention to the Germani and Germania Romana.

It will be useful to discuss some of the reasons for and manifestations of increased public interest in the Germani before moving on to an analysis of textbooks published since 1990. The survey that follows is necessarily brief and elliptic. Its significance lies largely in the influence that political developments and public and media attention bring to bear on the ways in which Latin can be justified in the modern school system. In 1987, J. C. S. Clunn's discovery of Roman coins and, more importantly, lead sling missiles in the Niewedder Depression near Kalkriese led to investigations at the site which determined that it was highly likely to be the location of the famous "Varusschlacht". ${ }^{197}$ The discovery, relating to the single most famous and significant historical event in ancient Germania, has significantly contributed to a resurgence of public interest in the Germani. Kalkriese has

\footnotetext{
196 Kipf (2006), 281-282. One of the re-issued textbooks was Ars Latina. The 1983 version is based on an edition of 1965. Its two passages on the Germani are: De Romanis, Germanorum praeceptoribus and Arminii et Flavi fratrum colloquium (Ars Latina [neubearbeitet] I, 57-59). The former passage describes the admiratio of the Germani for Roman civilisation (notably towns and comfortable villas) and their debt to Roman scientia agriculturae, since "Germanorum agri propter asperrimum caelum fertilissimi non erant, greges minores et peiores." The dispute between Arminius and Flavus is a straightforward dialogue based on Tacitus' Annals 2.9-10, presenting Arminius' arguments in favour of loyalty to his patria and Flavus' advocacy of accepting Roman superiority.

197 Schlüter (1993), 19-20. Bechert (2003), 30-36. Wells (2003), 45-55.
} 
become a popular tourist site and the Germani have reappeared as the subject of considerable media interest. ${ }^{198}$ Major German newspapers bear witness to a continuing interest in the Germani and particularly the Varusschlacht. Gesa von Essen cites a range of opinions that were evident in the mid-1990s, from Gerhard Schröder's dismissal of "[eine] Horde ungebildeter Mitteleuropäer" and Spiegel's description of "[ein] nicht qivilisationsfähiges Volk" to an attack on the supposed will of the "Zeitgeist" to prove "[die] Bedentungslosigkeit der Hermannsschlache' ${ }^{199}$ Debate about whether Kalkriese can truly be identified as the site of the Varusschlacht continues to be followed with interest by the media. ${ }^{200}$ The iconic status of the Upper German and Raetian limes (a standard topic of Latin textbooks) was reinforced by its inscription on the UNESCO World Heritage list in $2005{ }^{201}$

A process of Vergangenheitsbewältigung involving the re-examination of history and literature tainted by the interest of the Nazis has produced an increased volume of scholarly and artistic work on ancient Germanic topics since the 1980s. ${ }^{202}$ Heinrich von Kleist's play Die Hermannsschlacht, strongly favoured by the authorities under the Third Reich, disappeared from the German stage from 1945 until 1982 when Klaus Peymann, ahead of the Zeitgeist, directed the play in Bochum. ${ }^{203}$ The play has since risen in popularity, with an increasing number of wildly differing interpretations of it appearing in German theatres since the

\footnotetext{
198 The main features of the Museum und Park Kalkriese are a museum that displays the finds made on site and a reconstruction of the ancient earthen rampart at the foot of Kalkrieser Berg of which traces have been detected. The "Römerweg" is a winding path marked by metal slabs that is supposed to mark the progress of the Roman army across the depression. Many of the slabs bear embossed excerpts from ancient accounts of the battle. The slabs become scattered as the path progresses, representing the disarray of the Roman legions. The otherwise unremarkable field is also embellished with a Haus des Sehens (a large camera obscura in which a projection of the field is visible) and a Haus des Hörens, a shed into which a funnel channels the sounds of the quiet countryside ('just as Germanicus would have heard in 16 AD') to the exclusion of traffic noise from the nearby B218. There is, therefore, a concerted effort to engage the imagination of visitors and add appeal beyond the scientific interest provided by the museum. As Timpe (2006=1999), 454, points out, Kalkriese is a tourist attraction, not a national shrine as the Hermannsdenkmal once was, and while it gains much of its popularity from the legacy of the Hermann myth, it does not contribute to further mythologisation.

199 FAZ, 06/09/1996, citing Schröder at the opening of a symposium of the Varusschlacht, Spiegel, 28/10/1996, 'Die Germanen - unsere barbarischen Vorfahren'; FAZ, 17/09/1996, letters to the editor, cited by von Essen (1998), 7. 'Als die Legionen im Nebel verschwanden', FAZ 27/09/2007, Reiseblatt, 1. On 21-28 July 2007 the television network Arte screened a four-part series Die Germanen, the first three episodes of which concentrated on the clashes between the Germani and Rome ("Germanen gegen Rom", "Die Varusschlacht", "Entscheidung am Limes').

${ }^{200}$ For example: Berliner Zeitung 11/05/2002, 'Ein mächtiges Denkmal am falschen Ort. Wo schlugen die Germanen die Legionen des Varus? Zwei Städte streiten um die Hermannsschlacht'; TAZ 02/12/2004, 'Patriotische Mythen um ein Schlachtfeld', Wissenschaft 1.

201 The limes is grouped with Hadrian's Wall under the banner 'Frontiers of the Roman Empire' (see UNESCO website: http://whc.unesco.org/en/list/430/, accessed 26/06/08). For the limes in textbooks: LL $A^{10} I I$, 5-8 (with reconstruction sketch); Lat. Unt. MW II, 11-13 (with sketch and map); LL $A^{13} I I, 4-7$; Lat. Unt. Bornemann C I, 23-25 ('De castellis Romanis'), Roma $A^{2} I$, endpapers (map of Roman empire marking Upper German-Raetian limes but not Hadrians wall); Felix A, Das Lateinbuch, 152 (map of Deutschland zur Römerzeit); Felix, Das Sachbuch, 190-197; Cursus, 87, 157 (with reconstructions and a map); Salvete (2007), 104107 (chapter 'Weit draußen am limes'); Ostia I, 100-101 (German text and reconstructions); Prima, 200-203 (chapter 'Endstation limes'); Salvete (1995), 62-63, 80 ('Limes ille - opus, quod cetera superat laude', reconstructions). 202 Schmidt (2001), 285-6.

${ }^{203}$ Koberg (1999), 250-253.
} 
1990s. In 1996, a generically unclassifiable film named Die Hermannsschlacht, billed as a 'nobudget' epic comedy, was a surprise success at the box-office and received a number of warm reviews. In the film, the Romans speak Latin, the Germani speak German and Velleius Paterculus, Heinrich von Kleist and Christian Grabbe appear as characters in a pythonesque plot. ${ }^{204}$ Throughout the film, popular Germanic clichés are lampooned: Hermann wears a helmet with enormously exaggerated horns; Marbod marches into battle messily devouring a chicken drumstick; a tour guide and a bus-load of tourists are thrown into a pit at the order of an exasperated Varus for bursting onto the battlefield and insisting that the fighting did not take place near Detmold, and Hermann celebrates his victory with a hearty meal and a Maß of beer by the Hermannsdenkmal. These humorous references are a good indication of a widely recognised Germanenbild composed of fairly general barbarian clichés.

From the time of Napoleon until the end of the Third Reich, Arminius/Hermann as a political symbol served various visions of a united and victorious Germany, and the conventional "Lesebuchgermanen" embodied supposed German national values and strengths. This symbolism has largely been absent from mainstream politics since the Second World War, due primarily to a reaction against Nazi appropriation of Germania and Arminius as sources of myths. ${ }^{205}$ Furthermore, extreme-right groups have continued to show an interest in the symbolism of Germania and Arminius. ${ }^{206}$ Nazi and Neo-Nazi associations make it not only problematic but highly unappealing for other political groups to associate themselves with the symbolism of Germania, though in a few recent instances this has taken place.

An artistic project named HermannSchlachten07 produced by the Künstler der Wagenhalle in Stuttgart in 2007 included a play with a script based on the Hermannsschlacht dramas of Johann Schlegel (1743), Christian Dietrich Grabbe (1838) and, in particular, Heinrich von

${ }^{204 ‘}$ Neues aus dem Jahre 9', TAZ 22/07/1996, 3. 'Bedroht von fiesen Spiessen, macht Thusnelda sich frei' FAZ 04/06/1996.

205 Karl von See wrote the following in 1972: "Noch vor wenigen Jahrzebnten hat ... [Otto] Höfler... eifrig daran mitgewirkt, die Heldensage im völkischen Sinne zu interpretieren und ibr mit einem Schwall von hoblen Phrasen eine Ethik. zu unterschieben, die sie für den Kampf um Stalingrad brauchbar machte. Jetz̨t dagegen füblt er sich aufgefrufen, einem möglichen politischen Mißbrauch der Altertumskunde entgegenzutreten, - als ob irgendeine politische Bewegung der Gegenwart ein Interesse daran bätte, sich des Germanentums zu bedienen!” (Von See (1972), 2).

${ }^{206}$ Germania and Arminia were popular names for Burschenschaften, which were originally founded after 1815 as radical nationalist student groups but which are today strongly conservative. The Nationaldemokratische Partei Deutschlands, a party with Neo-Nazi associations, has named a party football club SV Germania - the members' notions of Germania are presumably vague, but the name must provide the desired nationalist symbolism ('Der Moment vor dem Gewaltausbruch', FAZ, 01/09/2007). Female writers of the far right have constructed a political Frauenbild based on their interpretation of Tacitus' Germanenbild, combining Volk-based, heroic and racist aspects of the National-Socialist Germanenbild with elements of modern Feminism (FAZ, 29/03/2001, 'Rechte Mädels suchen Schutz und finden ihn bei Tacitus'). 
Kleist (1808). ${ }^{207}$ The artists planned the project as a finale to their tenancy in a former Stuttgart railyard which was to be redeveloped under the aegis of the local government's "Stuttgart 21" property development and re-zoning plan. The Germani are supposed to represent the artists as a society on the fringe of an oppressive Hochkultur (represented by the Romans), yet Hermann's victory on behalf of the Germani is a violent dictatorial seizure of power that destroys the freedoms and principles which he claims to be defending. The project is based on an idealised view of Germania and a number of historical misconceptions.

[D]ie Bezeichnung deutsch leitet sich sogar vom Teutoburger Wald her.

Man kann mit Fug und Recht behaupten, dass sich das Germanien der Zeitenwende, kurz. vor und nach Christi Tod, in einem machtpolitischen Vakuum befindet, in dem ein relativ friedliches Gleichgewicht zwischen den Stämmen vorberrscht. Die einzelnen Gruppen sind in ibrer kulturellen Entwicklung frei von irgendwelchen fremdbestimmten Autoritäten. ${ }^{208}$

Despite the call for a new interpretation of Hermann's significance that is neither nationalistic nor centred on Germany, the Hermann of this production carries the associations of violence and dictatorship that have accrued to the political uses of the Hermann myth since the early $19^{\text {th }}$ century. ${ }^{209}$

The "2000 Jahre Varusschlacht" programme being planned for 2009 has the patronage not only of the Premiers of North Rhine-Westphalia and Lower Saxony but also Bundeskanzlerin Angela Merkel and the President of the European Parliament Hans-Gert Pöttering. The plans include exhibitions, artistic performances, international conferences and historical reconstructions. The museum project "Imperium Konflikt Mythos" will involve exhibitions at Haltern am See, Kalkriese and Detmold which deal with Roman imperialism in Germania, the V arusschlacht and the myth of Arminius respectively. Promotional material for the plans underway in Detmold and the Lippe Region ("Hermann 2009") shows an attempt to create new meaning for the myth of Hermann:

2009 - ein großes Fest für Frieden und Völkerverständigung in Europa und der Welt.

\footnotetext{
${ }^{207}$ For further information on these 'Hermann' dramas, see von Essen (1998).

208 The quotations come from the HermannSchlachten07 website,

http:/ / www.hermannschlachten07.de/informativ/varrusschlacht.htm (accessed 19/05/2008).

209 "Es ist Zeit, einen Gründungsmythos unserer Nation zu entstauben und neu zu verorten."

http://www.hermannschlachten07.de/informativ/varrusschlacht.htm (accessed 19/05/2008).
} 
With reference to Germany's reunification, the brochure continues:

Die deutsche Einheit kam ohne jeden historisierenden Gründungsmythos aus. Sie gründete sich vielmehr auf gemeinsame Werte von Menschenwürde, Demokratie, Rechts- und Sozialstaatlichkeit, die im Grundgesetz verankert sind und die die Deutschen mit ibren Nachbarn in Europa teilen...

Wenn Deutschland und Europa... im Jahr 2009 auf 2000 Jahre Schlacht im Teutoburger Wald zurückblicken, so geschiebt dies in einem neuen Selbstverständnis: Aus den nationalen Mythen, die der gegenseitigen Abgrenzung dienten, ist ein positives Miteinander geworden, das auf Verständnis baut und bestehende Grenzen mehr und mehr überwindet. ${ }^{210}$

The organisers of Hermann 2009, after acknowledging the political history of the Hermann myth and the myth's lack of potency in recent mainstream political movements, attempt to lend it new meaning. Hermann is to be a European symbol, not a German one, and is to represent international co-operation. It remains to be seen whether Hermann can serve as a symbol of this sort. What is clear is that Hermann and the Hermannsdenkmal retain their value as 'cultural capital' (which brings with it the attractive prospect of financial capital) but can only be acceptable to mainstream politicians if a clear break is made with the history of Nationalist symbolism attached to them.

Let us return now to Latin textbooks. The so-called 'third generation' are those produced in the years 1990-2004 and the fourth generation are those published since 2004. These textbooks follow the trend, demonstrated by Ostia, towards colourful presentation and attempting to provide a general introduction to the ancient world and the history of the Latin language. German texts with information about the topics covered in each section are a standard feature. ${ }^{211}$ In line with archaeological interest in the site at Kalkriese and increased public interest in the Varusscblacht, the limes, and Germania in general, these books include more material on the Germani than the coursebooks they are intended to replace. Germania Romana is a more common topic than in earlier courses and is also more

210 Brochure entitled: Mythos; 2000 Jahre Varusschlacht; Regionalprogramm Hermann 2009, published by the "hermannbüro" (sic), Detmold, in association with Lippekultur, Landesverband Lippe, Lippe marketing, Lippe Tourismus \& Marketing AG and Lippische Landes-Brandversicherungsanstalt. Further information about the planned activities can be found on http://www.imperium-konflikt-mythos.de/ (accessed 19/05/2008).

211 Kipf (2006), 280-292. Some courses include a variety of extra materials. Felix, for example, has a supplementary Sachbuch with more detailed historical and cultural background information than the Übungsbuch. 
common than Germania libera. In order to portray daily life in Germania Romana, there is an increase in the number of texts that are either freely invented or based only loosely on literary sources. Important themes are the effects of colonisation and romanisation, and the question of intercultural understanding or misunderstanding and the prejudices and biases to be found in Roman ethnography about the Germani.

The Richtinien currently in force for Sekundarstufe $I$ in Berlin take an approach which is a variant on the $D A V$ Lernzielmatrix. They set out three areas of competency that must be developed: linguistic competency, methodic competency and cultural compentency. Cultural competency in turn includes sociocultural, intercultural and literary components. Thematic requirements are arranged in four groups: $A$, Ich und die anderen; B, Der unmittelbare Erfahrungsbereich Jugendlicher; C, Das öffentlich-gesellschaftliche Leben; D, Der gesellschaftlich-kulturelle Bereich. Topic area C includes the "multikulturelle Gesellschaft" category in which the topics "Roms Verbältnis zu Germanen und Griechen", "ethnische und/oder religiöse Konflikte”, "religiöse Toleranz" and "Gallien" are prescribed. ${ }^{212}$ The Richtlinien for Sekundarstufe II at Gymnasien (most of which is valid in Berlin, Brandenburg and Mecklenburg-Western Pomerania) prescribe "Darstellungen fremder Völker bei römischen Autoren" as one of the topics to be covered under the rubric "Geschichte und Politik". 213 The competencies to be developed under this rubric include critical appreciation of the Roman political and historical sources, and an awareness of rhetorical manipulation and of the problems of war and peace in the Roman world. "Roms Verbältnis zu Germanen und Griechen" and "ethnische und/oder religiöse Konflikte" are prescribed themes for Sekundarstufe II that are already frequently treated in textbooks. $^{214}$

212 Senatsverwaltung für Bildung, Jugend und Sport, Rahmenplan für die Sekundarstufe I, Jahrgangsstufe 7-10, Gesamtschule, Gymnasium. Latein, 2./3. Fremdsprache, Berlin (2006), 17, 23.

213 Senatsverwaltung für Bildung, Jugend und Sport, Rahmenlehrplan für die gymnasiale Oberstufe, Latein, Berlin (2006), 20.

214 The following are some other relevant Lehrplan prescriptions currently in force. In Bavaria, the topic Die Römer in Germanien, Britannien und Gallien is set as a fachverknüpfendes/fachübergreifendes Vorhaben for year 7 of the Gymnasium and Die Römer in Deutschland is a topic in Latin, to be accompanied by trips to Roman sites in Bavaria

(see http://www.isb-gym8-lehrplan.de/contentserv/3.1/g8.de/index.php?StoryID=26287 and http://www.isb-gym8-lehrplan.de/contentserv/3.1/g8.de/index.php?StoryID=26287 accessed 30/06/2008). Hesse

(http:/ / download.bildung.hessen.de/unterricht/lernarchiv/lehrplaene/gymnasium/latein/LPGymLatein.pdf, last modified 20/02/2008, accessed 30/06/2008) follows the Kompetenz model. A proposed lesson plan for North Rhine-Westphalia involving Lorenzo di Pierfrancesco de Medici's Mundus Novus (1501-1502) as an example of early modern ethnography influenced by classical learning, structures its recommendations according to the Kompetenz model (http://www.standardsicherung.schulministerium.nrw.de/lehrplaene/upload/material/g8/G8_L_Beispielseq uenz_Vespucci.pdf accessed 30/06/2008). 
Salvete (1995) contains an exceptionally large amount of material on Germania Romana. ${ }^{215}$ The teachers' handbook states that an important feature of the approach taken by Salvete is reference to ancient archaeological sites and medieval localities in the pupils" "Heimatregion" (Salvete Alt, Lehrerhandbuch, 10). The locations that feature are Xanten (chapters xiv-xvi), Cologne (xxiv-xxvi), Trier (liii), the Weser region (xvii-xviii), the Limes (xix), Augst bei Basel (xxi-xxiii) and the Wartburg (il). In Salvete Alt, Germania Romana and medieval Germany serve as geographical points of identification for the pupils, who are expected to engage more readily with the Latin language by imagining themselves in a foreign ancient culture in a familiar place. There are numerous photographs of people, including children, wearing period attire in reconstructed ancient settings, notably the archaeological park at Xanten. ${ }^{216}$ This, combined with the setting of much of the book in places familiar to pupils, shows the attempt to bring the ancient world to life. ${ }^{217}$

A sequence of texts under the title Sieger und Besiegte, chapters 17-20 (Salvete Alt, 58-73), follows the experiences of a Roman soldier on campaign against the Germani in 16 AD. Chapter xvii is based on Tacitus' Annals 2.9-10, the argument between Flavus and Arminius across the river Weser. Arminius' arguments against Roman conquest and oppression are ranged against Flavus' advocacy of pax Romana (the title of the chapter). The narrative voice, a Roman soldier called Gallus, comes down in favour of co-operation under Roman rule:

Totum fere orbem terrarum Romani regunt. Etiam familiae meae, quae aliquando libertatem amisit, placet in imperio Romano cum Romanis vivere. C. Iulius Caesar enim Gallos, maiores meos subegit (Salvete Alt, 59).

215 The 1995 version of Salvete will henceforth be referred to as Salvete Alt. A completely re-worked textbook with the same title was published in 2006 and will be referred to as Salvete Neu. A 2007 Gesamtausgabe of Salvete Neu which includes all the lessons in one volume, is the one referenced here.

216 Photographs of costumed children occur, for example on pages 51, 57, 68. Dr. Markus Junkelmann's expedition across the Alps in legionary kit features on page 86 and a Germanic warrior in attire reconstructed according to clothing preserved in bogs on page 59. A course that uses photographs of costumed people in a similar way is Auspicia (see below). The influence of American and British historical re-enactment groups is evident. Amongst the recent proliferation of children's non-fiction books about the ancient world published in Germany are translations of British and American books, including some illustrated with photographs of people in re-constructed costumes. A popular example is: James, S., Röhrig, E. trans., Das alte Rom. Kultur und Alltag einer faszinierenden Epoche, Hildesheim, 2008. Historical re-enactment has grown in popularity in Germany and the 2009 V arusschlacht celebrations at Kalkriese may include an enormous re-enactment of the battle (see, for example, the report in the online magazine Chronico: http://chronico.de/erleben/menschenorte/0000405, viewed 22/06/2008 and the discussions on reenactment websites such as the Dutch site www.romanarmy.com, viewed 22/06/2008).

217 Kipf (2006), 326, comments on the use of the setting Germania to provide the subject of Latin with "Identifikationsmöglichkeiten". 
Gallus befürwortet die römische Weltherrschaft, ist aber auch stolz, auf die Leistungen der Gallier, seiner Vorfahren (Salvete Alt, 60).

The theme of conquerors and conquered combines with something of the lingua Latina viva philosophy in a bizarre passage called "Lingua Latina, quasi vinculum Europae".

Kathrin, eine Lateinschülerin aus Augsburg, hat Arminius, Flavus und Sabinus so aufmerksam verfolgt, dass sie sogar von ihnen träumt - sie sprechen Latein. ${ }^{218}$

Kathrin: "Dic mibi, Flave: Cur copias Romanas non reliquisti?"

Flavus: "Romani parcunt subactis et debellant superbos. ${ }^{219}$ Aliquando pax Romana erit per cunctas terras; ita et Germani in pace erunt. Itaque Romanos non reliqui."

Arminius: “Apparet multos Germanos ab armatis Romanis lacessitos, vulneratos, necatos esse. Hos Romanos e Germania libera pellam."

Flavus: "Hoc modo Germania erit terra, quae est divisa in partes duas: provinciam Romanam et Germaniam liberam."

Kathrin: "Bene a te instructa sum. Sed quid cogitas tu de imperio Romano, Sabine?"

Sabinus: "A Romanis multi quidem populi subacti, sed uno imperio coniuncti sunt; nunc pacem habent. Praeterea cunctae fere nationes orbis terrarum una lingua quasi vinculo coniunctae sunt: lingua Latina! Etiam in linguis nationum nondum superatarum verba Latina sunt, velut vinum, vallum, provincia, murus. Et nuper Romani cunctis fere nationibus civitatem dederunt; praeterea templa, viae, pontes ab iis exstructi sunt. Itaque nunc vita nationum iucunda est."

Kathrin (secum): "Licetne imperium Romanum cum Europa nostra comparare? Sed quid nobis deest? Una lingua! Lingua Latina...?” (Salvete Alt, 62-3).

Kathrin is an exceedingly diligent Latin student who starts to dream about the protagonists of the stories in her textbook. Just as in chapter xvii, this passage is based on the encounter of Arminius and Flavus across the Weser at Annals 2.9-10. The reader's sympathies are clearly directed towards Flavus, by whom Kathrin has been "bene instructa". Arminius is the proponent of division, of policies that will create a land "quae est divisa in duas partes": echoes of Germany's recently-ended division are unavoidable. Sabinus expounds a glorious vision of the Roman empire's unifying power. The image of Latin binding Europe together "quasi vinculo", not necessarily a positive one, is intended to be so here - a blessing which extends even into nationae nondum superatae. The potentially sinister nondum seems here to be

218 Sabinus is a Roman governor who appears in the preceding passage supervising the construction of the limes.

${ }^{219}$ At this point the silver-tongued Flavus references Virgil's Anchises, Aeneid 6.853. 
unproblematic. Sabinus goes on to list the benefits bestowed by Roman civilisation and concludes that the romanised lands have been made happy. To put the modern politics behind all of this beyond doubt, Kathrin suggests that the Roman empire is comparable with "Europa nostra".

Felix $A$, first published in 1995, is divided into fourteen thematic sections, one of which is "Germanien und Britannien". The eponymous central character of the course takes a group of German school children on a journey through time to the ancient world. Felix's personal qualities are described in some detail in the teacher's guide, the most important being his role as a capable and willing communicator with past times and foreign cultures, which reflects the importance of the Lernziel "interkulturelle Kompeten $2 .{ }^{220}$

The section Germanien und Britannien is introduced by a dialogue amongst the time-travelling school group. Someone comments on the virgin forest: "von Waldsterben keine Spur" - and somebody says that the Romans brought "Kultur statt Natur". The Romans are thus not only bringers of progress, they are also associated with pollution and damage to the environment (Felix A, 54). Umweltpolitik also occurs as a concern in Salvete Alt in the chapter "Fortschritt durch Romanisierung?" where a Roman talks to a Gaulish friend in Colonia Augusta Raurica (Augst bei Basel) and discusses his concerns about the environmental effects of Roman greed. ${ }^{221}$ He mentions the slaughter of wild beasts for entertainment, the levelling of hills to reclaim land and the effects of air pollution from furnaces in the city. "Mox tota natura ab hominibus delebitur." (Salvete Alt, 78). The inclusion of environmental concerns in some textbooks' treatment of civilisation and romanisation, alongside the increased focus on urban life in Germania Romana, means that the portrayal of Germania is no longer dominated by the forest full of wild beasts and hunters. Images of the Germani as farmers serve to illustrate the findings of archaeology which have corrected the

\footnotetext{
220 The University of Potsdam currently organises Lateintage based on a particular theme each year, which involve a variety of activities alongside seminars for teachers and for pupils. At the 2007 Lateintag a three-yearlong project entitled "BrAnD" ("Brandenburger Antike-Denkwerk") was introduced, with the purpose of involving schools, trainee teachers and academics in combined projects on set themes in order to produce materials for presentation at Lateintage and for publication online and in journal form. The overriding theme is "kulturelle Identität", and the introductory speech made by Prof. Ursula Gärtner at the Lateintag on 11 September 2007 stressed the importance of intercultural understanding in a modern world beset by "kulturelle Konflikte" and the notion of a "clash of civilisations". The speech has not yet been published. See http://klassphil.philfak.uni-potsdam.de/denkwerk/ (accessed 25/06/08) and http://klassphil.philfak.unipotsdam.de/denkwerk/Projektinformation_BrAnD.pdf. (accessed 25/06/08).

221 "Fortschritt durch Romanisierung?" seems to be an allusion to the well-known Audi motto "Fortschitt durch Technik".
} 
impression that the Germani inhabited impenetrable forest, a cliché inherited from Roman sources (see appendix, figures 8 and 9). ${ }^{222}$

Britannia and Germania are deemed suitable settings for the topic of colonisation in Felix because they are areas particularly familiar to German pupils. Emphasis is supposed to be placed on "Völker- und Kulturvermischung" with an awareness that such processes were "nicht immer friedlich" (Felix, Lehrerband, 132). The pupils' sense of identification with Germania is therefore directed towards an awareness of multiculturalism in their homeland, while accounts of war between Romans and barbarians (Caesar's invasion of Britain, Boudicca's revolt) are reserved for the Britannia section (Felix A, 154-157). ${ }^{223}$

Prima and Salvete Neu include passages set in Trier. The city suits the 'melting pot' theme as its location in Roman Gaul and modern Germany makes its changing cultural identity quite clear and illustrates the impermanence of national boundaries. An exercise in Salvete Neu asks pupils to identify on the map of the Roman empire in the book's endpapers: (1) which modern countries are included in the Roman province of Gaul, and (2) whether or not these countries' languages are descended from Latin (Salvete Neu, 101). The questions follow a passage in which a Gatus, a Gaulish boy, meets Lucius in the streets of Trier and the boys argue about Rome's conquest of Gaul.

Gatus: "Tace tu... Latrones estis! A populo Romano fines nostri occupati sunt, nobis terrae ereptae, vectigalia imposita sunt. Haec est pax Romana. Quid facitis in patria nostra?"

Lucius: “Asinus es! Nonnulli Galli etiam in civitatem Romanam accepti sunt. Nostrum est Germanos a finibus arcere. Nunc mercatores sine periculo negotia agere possunt."

Diu pueri inter se certant. Subito autem duo viri apparent: avunculus Gati, mercator, et pater Lucii, qui extra moenia villam rusticam possidet. Amici sunt, quod iam diu inter se negotia agunt.

222 See, for example, Germania 5.1, "terra, etsi aliquanto specie differt, in universum tamen aut silvis horrida aut paludibus foeda..." and possibly Caesar, BG 6.25-28, "buius Hercyniae silvae... latitudo novem dierum iter expedito patet...", although these chapters are likely to be later insertions into Caesar's text. Jahnkuhn (1971), 143-144, in a supplement to Gymnasium, refers to the results of archaeological research into settlements which reveals a pattern of settlements in cleared areas within a generally thickly-wooded landscape. Rives (1999), 130, refers to findings in Schleswig-Holstein from the time of Tacitus which show the creation of lightly-wooded areas in which cows and pigs were grazed and small clearings for buildings and fields. The Roman view of a land entirely covered by dense forest and marshes is an exaggeration based on the actual existence of large expanses of forest and marsh, but does not reflect the nature of settlements.

${ }^{223}$ It is not merely Britannia and Germania that feature prominently among the Roman provinces. Greece of course merits particular attention, alongside Gaul - usually in conjunction with themes from the Gallic Warand Prima features a section called "Die Wunderprovinz Kleinasien - die Römer profitieren vom Orient" (Prima, 151168). 
Tum pater Lucii pueros conspicit et admonet: "Cur certatis? Non solum inter Gallos et Romanos amicitia firma est, sed etiam inter me et avunculum Gati." Tum pueri obstupescunt (Salvete Neu, 101).

Pupils are asked to evaluate each boy's arguments and how convincing they are. Commerce plays an important role in Völkerversöhnung in this instance, and the importance of prosperity for evaluating Roman imperialism in Germania is evident in other textbooks as well. Felix includes a passage called "Toga und Kapurenmantel', in which the time-travelling school pupils arrive in Mogontiacum (Mainz) and discover a thriving centre of commerce:

Strepitum fabrorum, clamores venditorum atque emptorum, interdum gannitum canum audivimus. Nam in foro sunt frequentes cives hoc tempore (Felix $A, 58)$.

A Germanic merchant, Rinoldus, explains that he has served for twenty years in the Roman army and set up a business with his pension. He buys wool from Cisalpine Gaul, has it spun and exports the yarn to Rome for tapestry making. He worships Mercury, the Roman god of commerce. He explains that many Roman veterans have married Germanic women and settled in Germania. He profits from their buying thick cloaks to deal with the cold climate. The teacher's guide describes the subject matter as follows:

Dieser Text ('Interview' bəw. 'Reportage') ist frei erfunden; er soll die veränderung im Leben romanisierter Völker verdeutlichen. Anhand von Fragen wie Ü̈ ${ }^{224}$ kann sich ein Klassengespräch über grundsätəliche Vor- und Nachteile der Kolonialisierung entwickeln, gof. auch mit einem Hinweis auf aktuelle Situationen (Felix A, 135).

Clearly the intention is for a balanced discussion of the effects of colonialism to take place. The textbooks published since the 1980s show a change in emphasis from the war-focused portrayals of Romano-Germanic encounters prevalent in traditional Übungsbücher. This reflects the peaceful and productive interaction that had been ignored or downplayed in earlier periods. The emphasis can, however, shift too far. Roman conquest can seem inevitable, and resistance then appears to be troublesome intransigence that hinders the progress, prosperity and multiculturalism represented by Rome.

224 Section Üb ('Übungen') includes the questions: 1. what changes does Rinoldus think the Romans have brought to Germania? 2. what conclusions can be drawn from his worship of Mercury and penates, given that he is Germanic? 
Cursus examines the themes of colonisation, romanisation and prejudice through the case of Gaul, which reflects the continuing predominance of Caesar as an author for the Lektüre phase of school Latin (Cursus, 50-54, 194-195). The book also includes pictures from the Asterix comics (amongst the most widely known modern images of 'barbarians') and asks pupils to consider how the Romans are portrayed in the comics (Cursus, 50, 53). There is a dialogue in which a Roman, claiming that the barbaric Gauls needed to be civilised, is presented as arrogant (Cursus, 51). The last chapter in the book has an intercultural theme: "Mundus novus - Europas Begegnung mit der "Neuen Welt"” (Cursus, 220-221). In Prima, the chapter "Gallien wird römisch" bears the sub-heading "Zivilisation für Mitteleuropa" but invites reflexion on the meaning of "Zivilisation" and "Kultur". A passage based on Caesar's description of the Druids at BG 13-18 (Prima, 175) leads to questions about the ramifications of religious leaders' bearing so much power in other areas of society. In addition, two romanticised $19^{\text {th }}$ century paintings of Vercingetorix (by Lionel Royer and Henri-Paul Motte) are reproduced, accompanied by a question about the painters' intentions in portraying Vercingetorix the way each of them does. Gaul thus provides themes of romanisation and the reception of ancient sources which are similar to some of the common themes highlighted in chapters on Germania.

Prima includes an especially comprehensive treatment of the topic of ethnic or racial stereotyping - "Vorurteile" (Prima, Lehrerheft, 53-4). The chapter Typisch germanisch? (Prima, 208-212) includes a passage with the same title in which two fifteenth-century scholars at the monastery of Hersfeld, the German Conradus and the Italian Mauricius, discuss the recently-discovered Germania.

Ohne auf die zeitliche Distanz zu achten, berogen die Gelehrten des 15. Jabrhunderts die Beschreibung der Volksstämme des alten Germanien auf ihre eigene Zeit. $\cdots$

MAURICIUS: Legistine omnibus Germanis corpora magna esse? Si res ita se habet, quaero, cur tu tam parvus sis.

CONRADUS: Verba eiusmodi dicens me persuades te stultum et ignarum esse: Tot annis praeteritis me Germanum antiquum esse putas!

[The argument continues, with Conradus suggesting a trip to the library to read "diversos libros de factis et moribus Germanorum scriptos" so as to dispel Mauricius' prejudices.] 
CONRADUS: Etiam Tacitus dixit Germanos pudorem magni aestimavisse et...

MAURICIUS: ... et liberos eorum in omni domo nudos atque sordidos vivere.

CONRADUS: Talibus verbis a te dictis nunc haec tantum intellego: Tu durus et iniquus et invidiae plenus es! Abi potius, Maurici, aliter Germanus quidam minimus pudorem suam ommittet et odio incensus hostem Romanum doloribus maximis afficiet! (nach Tacitus, Germania). (Prima, 209).

The next passage, adapted from the $14^{\text {th }}$ century Liber de Introductione Loquendi by Philipp of Ferrara, describes how a Teutonicus (glossed as "Germane"), tricks two Lombardi (glossed as “Lombarde (Norditaliener)'), who have attempted to outwit him (Prima, 211). Questions after the passage ask pupils to consider stories or jokes they know that begin with a formula like that seen here ("quodam tempore duo Lombardi forte una cum Teutonico iter facientes..."). It also sets the following task:

Ermittelt (₹:B. durch Fragen in der Familie, an einer Austauschschule, in Erdkunde oder durch Recherchen im Internet), welche Vorurteile es heutzutage in anderen Ländern über unser Land gibt. Könnt ibr den Ursprung wenigstens einiger dieser Vorurteile berausfinden? (Prima, 211).

The review section at the end of the chapter presents three cartoons with captions describing particular stereotypes about the Germani (Prima, 212) - “Abhärtung des Kindes ... Die Germanen treiben kaum Ackerbau ... Sie liegen bäufig auf Bärenfellen und schlafen" (Prima, Lehrerheft, 54) - and invites criticism of these stereotypes (see appendix, figure 10). There is also information on the influence of Roman civilisation on Germanic and modern German culture and a short German text about the popular topic of the battle in Teutoburg Forest, accompanied by pictures of finds from Kalkriese. Prima presents a lively variety of passages and topics related to the Germani, most of which are loose adaptations of original Latin passages. The keynote of the first section on Germania is the questionable nature of Roman sources and the information they present. The introduction in German gives a good, brief explanation of what needs to be considered when assessing information about the Germani. In one passage a Roman soldier preparing to set out for the limes discusses Germania and its people with his mother. She speaks of the Germani as fearsome barbarians while her son attempts to assuage her fears. Notably, a paraphrase of Germania 2.1 expresses the sense of the original: "Quisnam Italia relicta Germaniam, asperrimam regionem, peteret, nisi si patria esset? Non solum bieme tempestas ibi saeva est!" (Prima, 193). ${ }^{225}$ There is also an

225 See discussion of Roma above for examples of misinterpretations of the same passage from Tacitus. 
adaptation of the curious description of elk-hunting in Caesar, BG 6.27 (Prima, 195). The next section is based on Tacitus' description of the Batavian revolt. Veleda describes the benefits and hardships of her status as a seer. The Ubii refuse to slaughter the Romans amongst them at the order of the Batavians, pointing out the now insoluble ties that bind Romans and Ubii (Prima, 196-199). Unlike the enthusiastic description of the limes in Salvete Alt ("limes ille - opus quod cetera superat laude"), Prima includes a dialogue that questions Domitian's assumption of the title Germanicus and asks whether the limes are a sign of strength or of vulnerability. Another passage describes trade (rather than fighting) at the limes, and the characters include a Roman soldier who is proud of his Germanic mother who has successfully negotiated a low price for a goose by speaking with a merchant in his native Germanic tongue rather than in Latin (Prima, 200-203). The next short section carries on the interplay of Roman and Germanic peoples and cultures into the middle ages with a scene in a Carolingian monastery.

The "Begegnungen im Norden" section of Salvete Neu (100-113) deals briefly with the Roman conquest of Gaul and Germania west of the Rhine, placing its emphasis instead on "das friedliche Nebeneinander von Römern und Einheimischen" (Salvete Neu, 102). The father of a Roman boy who has been arguing with a Gaulish boy appears as a mouthpiece for intercultural tolerance and understanding as he attempts to dispel his son's prejudices about Druids. Both Prima and Salvete Neu directly address questions of ethnic stereotyping and use the reception history of Germania, German settings and Germanic characters to make the point more immediate to pupils, while debunking clichés about the Germani. Occasionally this is achieved through dialogues that come across as somewhat forced attempts to promote the interkulturelle Kompetenz required by Lehrpläne, but the treatment of Germania in the context of its reception in Prima opens up a rich topic for discussion and presents a worthwhile approach to the interpretation of the text.

Arminius, often still popularly known as Hermann der Cherusker, is such a widely known historical and mythical figure that he earns a mention in most textbooks published since the 1990s. The introduction to Germanien und Britannien in Felix $A$ treats the name Hermann as one familiar to pupils.

FELIX So simpel war es nicht. Die alten Germanen haben sich doch nicht einfach ergeben.

- $\quad$ Ach ja, da war doch Hermann, der Cheruskerfürst! Die Römer nannten ibn aber noch anders. Hat der nicht den Varus überlistet? (Felix A, 144). 
Although the coursebook Felix makes no further mention of Arminius, there are three pages in the Felix Sachbuch on the battle in Teutoburg Forest, which draw on the finds at Kalkriese and refer to the symbolic importance of the battle and "Hermann" for the national movement of the $18^{\text {th }}$ and $19^{\text {th }}$ centuries. In Salvete Neu, there is a section called Schattenseiten der Macht, in which the passage Die schreckliche Nachricht presents in dialogue form an argument in the imperial household as Livia blames Augustus for an unwise plan and he in turn blames Varus' recklessness. Following a German text about the battle comes “Arminius: Held oder Verräter?” which adds the Roman point of view to the Germanic one: "A Germanis liberator Germaniae apellabatur, a Romanis proditor" (Salvete Alt, 117). ${ }^{226}$ The Hermannsdenkmal has been one of Germany's most popular tourist destinations ever since its completion in 1875. Although the modern Teutoburger $W$ ald is no longer considered to be the site of the V arusschlacht, its role in the popular imagination is afforded recognition, due to the importance of the modern myth of Hermann and its contribution to contemporary interest in Arminius and the Germani. ${ }^{227}$

Eller (1987) refers to the motivational value of the topic 'Germani' that stems from halfformed romantic notions - the sense of the heroic, of adventure and danger and vague evocations of the Nibelungenlied. Arminius, he says, is "noch immer für den Jugend eine Art Nationalheld". He sees value in dispelling idealised notions and revealing that not all Germani were like Siegfried (though his own Germanenbild - see above - relies rather too heavily on Roman topoi). ${ }^{228}$ Similarly, Prima recognises the motivational value of a pupil's emotional response to his or her first impressions of the Germani ("So schlicht lebten unsere Vorfabren?' is an imagined response to the picture on page 192 of the textbook, see appendix, figure 9), but makes it clear that such impressions must always be tempered by bringing discussion back to the realities and limitations of our historical knowledge (Prima, Lehrerheft, 48).

Auspicia (2005), a course produced in Bavaria, has been the subject of considerable debate and has been widely criticised as reactionary. ${ }^{229}$ The first volume, "Roms Aufstieg zur

226 Of course, it was a Roman who coined the phrase liberator Germaniae, but the passage successfully makes the point that there are two sides to the story.

227 Timpe (1999=2006), 454. A supplementary volume to the Prima course features a photograph of the Hermannsdenkmal on its cover. Prima. Prüfungen 2, Zu den Lektionen 22-58, Burdich, J., Czimmek, R. (2008) Bamberg. Felix, Das Sachbuch includes information on the uses of the Hermann myth by nationalist movements and includes a sketch of the Hermannsdenkmal (Felix, Das Sachbuch, 189).

228 Eller (1987), 310-311.

229 The debate in Forum Classicum can be seen through the following reviews: Hoffmann (2004), 252-255 praises the book's focus on grammar rather than "überfordernde Texte"; Westphalen (2004), 255-257 expresses grave concern about the course's portrayal of the ancent world; Schirok (2005), 69-75 mentions, along with 
Weltmacht' returns to the 'war and grammar' formula that was generally cast aside from the early 1970s. The book's first six chapters teach verb forms of the first and second conjugations and contain no texts. The first loan-words of Latin origin that are presented to pupils are Terror and Exerzitien. The subject matter is to a large extent adapted from the traditional sources: Caesar's Gallic War and Livy's description of the Second Punic War. The Germani appear in eight of the 79 chapters. The titles of the passages would not be out of place in traditional Übungsbücher. Die Angst der Römer vor den Germanen; Die Siedlungsformen der Germanen; Cäsar und Ariovist; Ariovist; Unvereinbare Gegensätze (between Caesar and Ariovistus); Tacitus und Cäsar berichten von den Germanen; Römer im Krieg mit Germanen; Die Römer in Deutschland.

Auspicia returns to the uncritical relaying of Roman ethnographic clichés and brings about the return of the Lebrbuchgermanen.

$$
\begin{aligned}
& \text { "Apud Germanos antiquos magnae silvae sunt... Ibi se exercent et bestias superare } \\
& \text { temptant... Germani bella contra adversarios saepe parant. Ante bellum feminae viros } \\
& \text { monent: "Temptate et superate adversarios!" Post bellum magnum animum virorum } \\
& \text { laudant. Circum tecta agri sunt; ibi viri et feminae magna industria laborant (Auspicia } \\
& \text { I, 64). }
\end{aligned}
$$

Unlike Prima, Salvete, Cursus and Felix, which present Roman information about the ancient Germani as a matter for debate, Auspicia simply asks questions about the 'facts' it has presented: "Welche Unterschiede zwischen den Römern und Germanen kannst du den Texten dieses Kapitels entnebmen?" (Auspicia I, 65). Numerous statements by Caesar and Tacitus that are the product of ethnographic convention or political expediency are presented baldly as fact, the German introductory material being no more critical than the simple Latin passages for translation. After the passage Die Erriebung bei den Germanen war hart, the questions, "Wodurch unterschiedet sich nach den obigen Texten die Erriebung der Buben in Rom und bei den Germanen?" and "Warum fürchten sich die Römer vor den Germanen?" (Auspicia I, 99) merely encourage simplistic answers based on the clichés presented and imply that these may be accepted as fact. The practice sentences on page 63 read like a textbook of the early $20^{\text {th }}$ century:

methodological concerns, the book's opening with the vocabulary of terror and war; Fleming (2005), 75-78 recaps Westfalen's concerns and adds criticism of numerous errors; Dürbeck (2005), 78-80. 
1. Ein Lehrer erzählt römischen Knaben über die Kindheit (pueritia) der Germanen: 2. 'Sie sind oft mit Freunden zusammen und rufen sie (eos) aus den Häusern berbei. 3. Obne den Befehl der Männer üben sie sich (se) von Kindheit (pueritia) an, denn sie sorgen sich (baben Sorge) für (über) ihre Heimat. 4. Es ist schön, für das Vaterland Rubm qu erwerben (bereiten).' (Auspicia I, 63).

The tone is often germanophilic. A passage entitled "Wechselnde kriegerische Erfolge" tells us "Sed etiam Germani de Romanis victorias interdum reportaverunt. Opus clarum Arminii erat Varum imperatorem superavisse. Gloria Arminii ad sidera volavit' (Auspicia I, 100). Auspicia is however, used only in Bavaria and while it shows reactionary tendencies, it does not represent the vast majority of textbooks in use in Germany today.

In general it can be observed that the importance of Germanic antiquity and particularly Germania Romana as the subject matter of Latin textbooks has increased since the 1980s. Germania Romana is seen to offer geographical points of identification to aid pupils in their engagement with Roman culture. Although some elements of the uncritical and clichéd traditional Germanenbild persist even in new textbooks of the 1970s (as well as in new editions of older textbooks), from the 1980s courses such as Ostia have encouraged a more critical approach to sources of information about the ancient world. This development is a positive consequence of the model outlined in the $D A V$ Lernzielmatrix.

Barbarian clichés and popular myths about the Germani (which mostly coincide with features of the traditional Lehrbuchgermanen) are recognised as a useful way to pique the interest of pupils but most textbooks make sure to debunk such misconceptions. Usually adaptations from Tacitus' Germania are accompanied by some indications of the text's tendentious nature or by questions that invite criticism of the information presented.

Along with the many texts based on Tacitus' Germania, Annals and Histories as well as Caesar's Gallic War, we find Latin sources on late antique and medieval Germany. In addition, it is usual for textbooks to include passages that are not closely based on ancient literary sources, particularly in the treatment of Germania Romana, and to rely on the findings of archaeologists which point to the intermixing of Germanic and Roman people and culture - a phenomenon which lends itself to the requirement for teaching 'cultural and intercultural compentency'. Frequently, as in Felix, Salvete Alt and Salvete Neu the benefits of romanisation are presented primarily in terms of economic progress. 
Passages are often presented as dialogues whether they be 'artificial' or adapted from Roman sources. Sometimes - most obviously in the Salvete books - the result is the invention of characters whose utterances are more modern than ancient, who act as expositors of learning targets (Lernziele). While such techniques can lead to productive discussion of history presented from different points of view, they can present a misleading picture of the past by attributing current attitudes and political views to ancient characters. The older version of Salvete is an example of a course which offers in numerous chapters a varied and stimulating portrayal of Romano-Germanic relations, but also allows contemporary politics and "Europaenthusiasmus" to influence its representation of Germania Romana, which idealises the 'civilising mission' of the Roman Empire. ${ }^{230}$ This goes against the grain when most coursebooks encourage Ideologiekritik in place of uncritical acceptance of Roman values and portrayals of themselves and other peoples. ${ }^{231}$

Since the 'revolution' in Latin teaching in the 1970s, there have been clear tendencies towards encouraging or directly presenting criticism of traditional ideologies and idealised portrayals of the ancient world. ${ }^{232}$ The portrayal of the unconquered Germani has generally benefited from a demythologising approach to the traditional Germanenbild of textbooks and of the popular imagination, based on the work of scholars such as Dieter Timpe, Manfred Fuhrmann, Allan Lund and Alfons Städele. Fuhrmann, Lund and Städele in particular have addressed the reception of Germania in schools. The portrayal of Germania Romana has been influenced by archaeological discoveries and the increasing emphasis on research in non-military Roman and Romano-Germanic sites in the Rhine provinces. A defining theme of archaeologically-based historical research has been the co-operation between Romans and Germani (and Gauls) within the empire (and, in many cases, across the border) and this emphasis has permeated textbooks since the 1970s. Frequently, however, the influence of the Roman Empire on the pupils' homeland has been cast in the light of modern European politics. While the requirements, laid down in Lehrpläne, for intercultural understanding and tolerance and for insights into the nature of ancient societies are laudable, there is a tendency to try to make the subject matter even more 'relevant' (as part of the continuing need for the subject to justify its existence) through

230 Timpe (2006), 217-218: "Reichsdeutscher Katzenjammer und Europaenthusiasmus vereint haben sich gelegentlich zu der Ansicht verstiegen, die Schlacht im Teutoburger W ald und ibre Folgen bätten unsere barbarischen Vorfahren von den Segnungen der römischen Kultur ausgeschlossen."

${ }^{231}$ For the encouragement of critical attitudes towards Roman values in textbooks see Kipf (2006), 320, 325, $327,329-332$, although there are also some examples of idealisation, as in the way Augustus is represented in some works including Roma: Kipf (2006), 332-3.

232 Auspicia (see discussion above), which points to the continuing influence of traditional Latin textbooks amongst a small number of Latin teachers and educationalists, must be considered separately from other current Latin courses. 
references to modern day social and political concerns. Such an approach can cause modern ideologies to impinge upon the portrayal of the past in an obtrusive fashion, so that rather than promoting understanding of foreign societies, these societies (Germanic, Roman, Romano-Germanic) may be viewed through the filter of current trends - a return to tendencies (in the case of the Germani, the conflation of the values that are identified as germanisch and deutsch), which most experts on Germania and on the teaching of Latin have striven, for the most part successfully, to eliminate from the subject. 


\section{Conclusion}

Manfred Fuhrmann's comments on a 1979 essay by Heinrich Böll illustrate the importance of taking reception history into account when interpreting Tacitus' Germania. As part of the series "Die 100 Bücher der Weltliteratur" in the newspaper Die Zeit, Böll interprets Germania from a stance of considered naivety, without recourse to its reception history. In the course of his review, Böll develops an identification of the Germani with the Germans. Tacitus' work is,

...immerbin eine der ältesten, wenn nicht die älteste Auskunft über unsere 'Vorfahren'. Waren sie's wirklich? Sind nicht viele von ibnen ab-, andere zugewandert, hat sich nicht einiges 'eingemischt' und ... natürlich sehr vieles verändert? ... Die Klima-Angaben bei Tacitus treffen zum Teil heute noch zu ... Heimat war's eben für die Cherusker und Brukterer, Sugambrer, Tencterer, Usiper ... und wie sie da alle gebießen haben, sie, aus denen später die 'Deutschen' wurden.... Thing, Rechtspflege, Wehrwesen... da ließe sich zitieren und belegen, daß diese nachmaligen "Deutschen" ibre Ordnungen hatten. ${ }^{233}$

Fuhrmann points out the consequences of Böll's approaching the text "als wäre er der erste Leser":

Das Beispiel Bölls zeigt, daß man Texte wie die Germania nicht naiv lesen wollen darf. Einstige Febldeutungen, nur noch als schattenhafte Reminiszen₹ verschwommen gegenwärtig, steuern das Verständnis in einer Weise, die dem Verstehenden selbst verborgen bleibt. $^{234}$

Fuhrmann's conclusion is relevant to all post-Third-Reich reception of Germania:

[Bölls] Urteil zeigt, daß Schriften wie die Germania nicht obne die Geschichte ibrer Wirkung vermittelt werden dürfen; dies ist so etwas wie ein Stück stets anfs neue zu leistender Aufklärung - einer Aufklärung, die einer Remythisierung des endlich Entmythisierten zuvorkommt. ${ }^{235}$

233 Böll, H., 'Tacitus. Germania', Die Zeit, 02/03/1979.

234 Fuhrmann (1989), 182, 183.

235 Fuhrmann (1989), 183. 
Böll's attempt to reach a fresh and unbiased intepretation of Germania suffers under the weight of tradition, the influence of centuries of Lesebuchgermanen (or Lebrbuchgermanen) and the experience of the Third Reich, which necessitate a conscious effort to create a revised Germanenbild through critical engagement with ancient source material. Aufklärung is necessary to prevent past misreading and misuse of the text from influencing one's understanding. In schoolbooks, bald adaptations of Roman authors' descriptions of the Germani will invariably result in the renewal of Germanic clichés. Most of the textbooks produced since the 1990s have pertinently addressed the unreliability of Roman ethnography as a source of information about the Germani. In numerous instances, however, this is not the end of mythologising. Aufklärung may forestall or preclude remythologisation, but equally it may clear the way for it. The discussion of the "bermann2009" celebrations in chapter 5 shows how exhibitions in the Lippisches Landesmuseum Detmold on the reception history of the myth of Hermann (Aufklärung) are to be part of a festival with the key-words Frieden and Völkerverständigung - a politically and economically motivated attempt to attach new meaning to the symbol 'Hermann' and make him a symbol for Europe rather than Germany. ${ }^{236}$

From Ostermann's Übungsbücher to the post-1945 textbooks which looked back to the reforms of the Weimar Republic, there was little change in the way the Germani were portrayed. There were, however, considerable developments in the relationship of the textbooks' Germanenbild to contemporary politics. Ostermann's books translate Germani with die Deutschen and vice versa. The Nationalistic interpretation of Germanic antiquity that began in the time of Napoleon continued to be influential. After 1871, Germanic resistance to the Romans, especially Arminius' victory in Teutoburg Forest, was seen as the beginning of a historical process that culminated in the creation of a united German empire. The Germani represent Germany in the ancient world, and the characteristics assigned to them are part of a canon of traits regarded equally as German and Germanic. ${ }^{237}$ In some respects, however, 'ancient Germany' is portrayed as unlike present-day Germany and the Germani are in many respects noble barbarians.

In its use of Germanic material, Ludus Latinus, which first appeared in 1926, follows the principle of Kulturkunde, according to which Latin as a foreign language gains its significance from connexions drawn with German language and culture. Linguistically, this requires the centrality of the mother tongue at all times, and the series begins with Latin

${ }^{236}$ Fuhrmann uses 'Zuvorkommen' to mean 'to forestall' or 'to preclude', but it can also mean 'to precede'.

237 The difference between germanisch and deutsch was frequently blurred by the universal application of the latter term. 
words in use in Germany. After the first edition, the word Germanen becomes more common than Deutsche as a translation of Germani but the former continues to be used. Kulturkunde influences the choice of subject matter, which includes a large and eclectic selection of topics from German myth, fairytales, history and daily life alongside adaptations of ancient sources. Several narratives about the Goths - relatively uncommon material for textbooks - are included in volume II (1969). Ancient Germanic and modern German material alike, the overwhelming majority of which occurs in the first two books (for use in Sexta and Quinta), is intended to provide links with the pupils' culture and homeland and a sense of familiarity in the early stages of learning a language not only foreign but ancient. Along with the child-friendly storybook subject matter of the early chapters, Ludus Latinus includes the traditional abundance of warlike material and the portrayal of Romano-Germanic encounters is dominated by war.

The Third Reich stands out from other periods because racism was at the centre of its ideology and its reformed education system. The Deutschtümelei that had been prominent throughout the Second Reich and the Weimar Republic was now allied to biological theories and racialised historical models, notably those of Günther and Rosenberg. The identification of Greeks and Germani as 'Nordic' races and the Romans as a 'nordisch bestimmte Rasse' was used to justify ancient language teaching and the survival of the Humanist Gymnasium as a national type of school which promoted "Rassenbewusstsein". In some respects Nazi requirements could be fulfilled without major changes to the traditional content of textbooks: wehrgeistige Erziebung could be related to the existing predominace of the topic of war; Kulturkunde had already paved the way for including a significant amount of German and Germanic subject matter, particularly early on in a coursebook. The Germani were portrayed as a Hochkultur and any description of them as barbarians was dismissed as a lie. The stereotypical Nordic phenotype of a well-built, blond-haired, blueeyed warrior people was frequently promoted by reference to Germania. Some textbooks used German headings to present the passages in terms of the ideology of Volk and Fübrer.

After World War II, Humanist education was widely thought to have failed to prevent Nazi barbarity, and its perceived elitism, detachment from reality and irrelevance to the modern world contributed to its increasing marginalisation. Textbooks produced in this period reflect a failure to make the sort of progress that was necessary to restore Latin to a strong position in schools and in public favour. They reflect a return to the traditions of Latin teaching that predominated under the Weimar Republic. The reaction against Nationalist justifications for Latin teaching and especially the misuse of Germanic antiquity under the 
Third Reich are reflected in the excision of Germanic material from new editions of Weimar textbooks and the scant presence of Germani in new publications.

The new 'generations' of textbooks published from the 1970s onwards show the increased importance assigned to subject matter and knowledge about ancient history and culture. Postclassical, medieval and modern Latin traditions receive more attention. The emphasis on war is reduced. Increased public and academic interest in the Germani, most noticeable from the 1980s onwards, is reflected in the increased number of passages with Germanic material. Usually background information in German is supplied so as to put adapted passages of Caesar and Tacitus into context. Roman ethnography about the Germani can thus be understood in terms of ancient ethnographic traditions, interpretatio Romana, and the political and literary purposes of the author. Some courses discuss the Nachleben of Germania and the appropriation of Roman Germanenbilder from the Renaissance onwards. Texts on the Germani are frequently used as part of a topic such as 'Rome and foreign peoples' to introduce themes such as intercultural understanding and misunderstanding, ethnic prejudice and the attitudes of a 'civilised' culture towards one which is viewed as 'barbarous'. 238

The topic Germania Romana is brought up in most second-generation and later textbooks. Passages set in Germania Romana often rely heavily on the results of archaeological research into provincial history. The Latin narratives are therefore to a great extent freely invented, which gives greater scope for creating connexions with the modern world. The portrayal of Germania Romana is far from unselfconscious. In a number of textbooks the influence of contemporary political correctness is apparent - occasionally blatantly, as in Salvete Alt. The topic of colonisation, when it concerns Germania Romana, often leans too far towards a portrayal of Rome as an enlightened multicultural model for the European Union.

Arminius continues to be mentioned in most textbooks, but often in background information rather than in Latin passages. The examples from Salvete Alt and Salvete Neu present different points of view from the traditional heroisation and celebration of his victory. The painstaking battle descriptions common in traditional textbooks have given way to passages which draw attention to other aspects of the clades Variana, such as arguments for and against Roman conquest, the assignation of blame on the Roman side and the question of Arminius' treachery. Accounts of archaeological evidence of the 'real'

238 Auspicia breaks with many modern trends and can be regarded as something of an anomaly. 
Varusschlacht at Kalkriese are commonly included. Arminius no longer plays the role of the champion of Germany.

While recognising the emotional interest that stems from the idea of the Germani as the 'ancestors' of Germans, most modern textbooks aim at Aufklärung and the important task of debunking myths about the Germani. Whereas Germania libera is generally demytholgised, imaginative reception of literary and archaeological sources continues the process of casting the ancient world in the mould of the modern in narratives on Germania Romana which are considered relevant not merely to Germany but to Europe. 


\section{Appendix - The Germani in schoolbook illustrations}

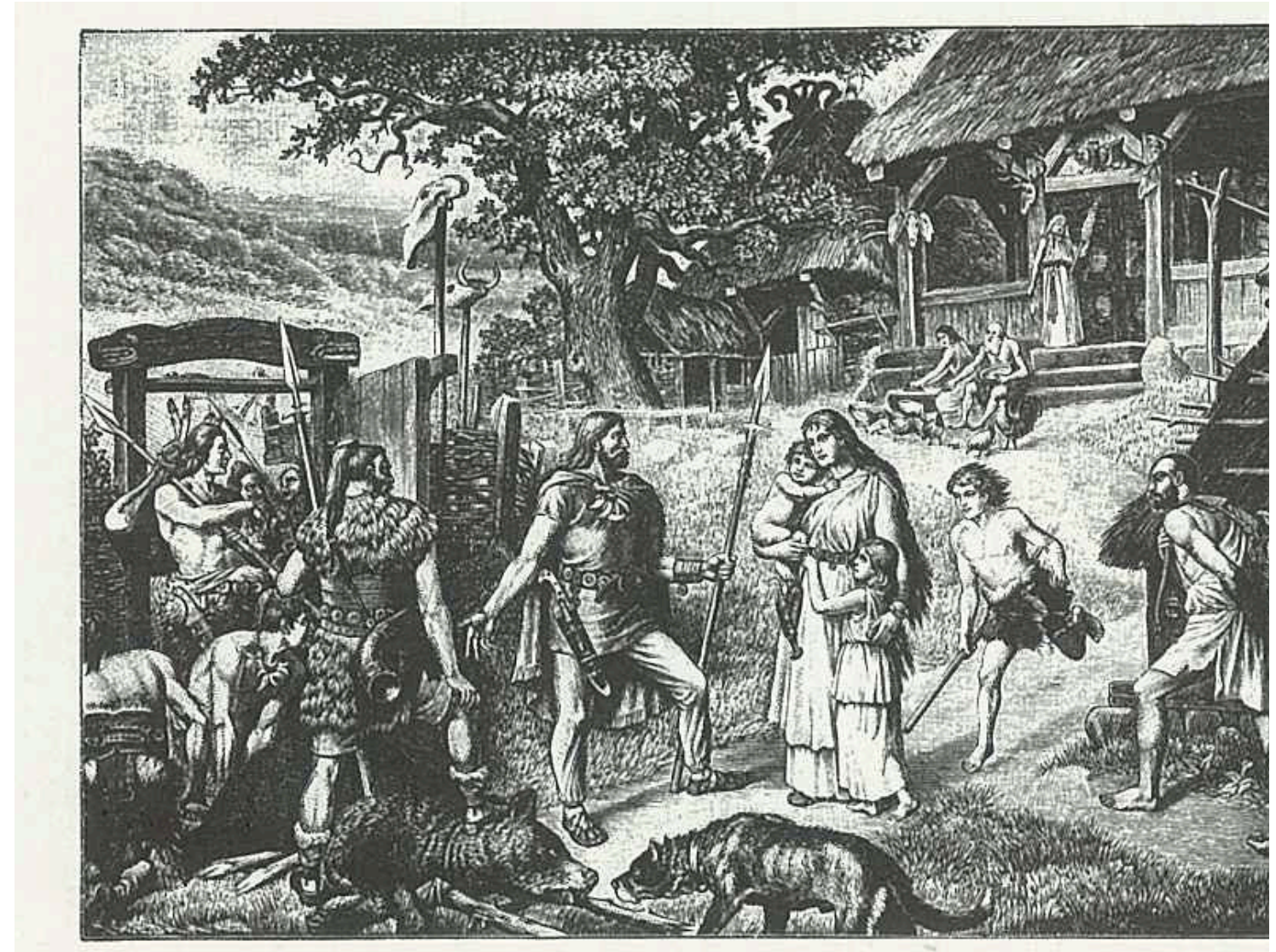

Sermanijđjes Bsehöft

Figure 1: The frontispiece of a $19^{\text {th }}$ century school edition of Tacitus' historical works (Weidner, A., ed. Tacitus' bistorische Schriften in Auswabl für den Schulgebrauch herausgegeben. I. Teil: Text, Leipzig, 1896). The picture is reproduced by Maier, ed. (1989b), frontispiece, and in Felix (2004), 149.

Many traditional Germanic clichés are evident. The men, posturing heroically, are powerfully built and even the boy is energetic and somewhat muscular and carries a stick which presages the weapons that he will later bear like the men in the picture. One of the hunter-warriors wears animal skins. The high pony tail worn by some of the men was a common way of portraying the Germani before the side-knotted Suebenknoten was discovered on bog corpses (see figures 2 and 4 for the hairstyle seen here and figure 6 for an ancient sculpture with side-knotted hair). 


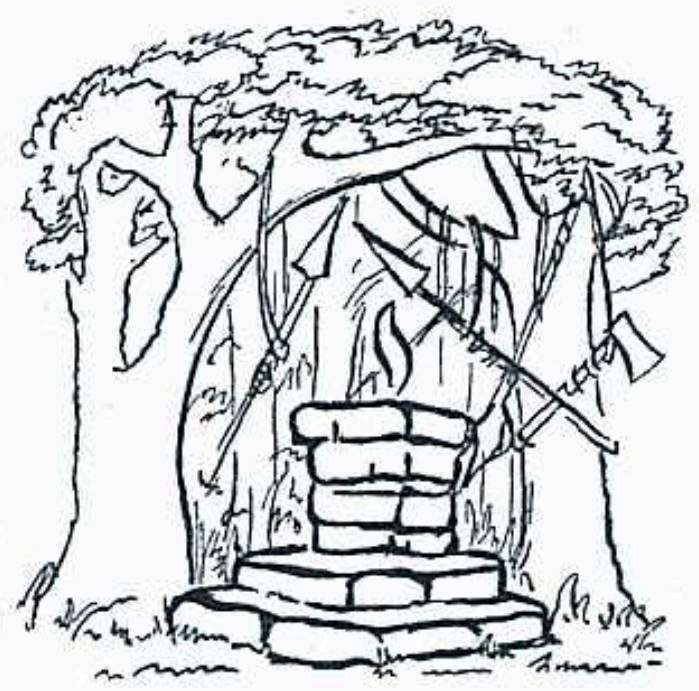

\section{Der Khein.}

1. Rhenus fluvius Germaniae est (iit). 2. In ripis fluvii Rheni vici et villae sunt (in๖). 3. Germani Rhenum amant et laudant 4. Saepe poetae Germanorum de Rheno narrant et fluvium

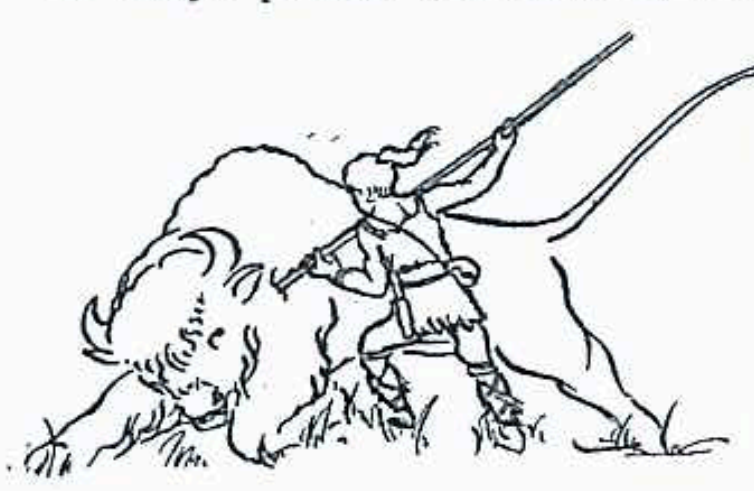
celebrant. 5. In Rheno insulae sunt. 6. Liben ter Rhenum spectabam et in fluvio navigabam. 7. Ger. mania patria Germanorum est. 8. In silvis Germaniae, discipuli, olim cervi et lupi et ursi et uri habitabant: 9. Germani cervos et lupos et ursos et uros hastis et sagittis et gladiis necabant. 10. Incolae Germaniae in silvis et campis habitabant et in lucis deis sacrificabant. 11. Germani summo deo equos immolabant.

Figure 2: Ludus Latinus I, first edition (1926) page 6. The first picture shows a sacred grove in the forest, festooned with weapons. The second portrays a hunter with the wild hairstyle often imagined upon the Germani (see figure 1), in mortal combat with a giant aurochs. The Germani were almost always armed, whether as hunters or warriors, in illustrations of the time. The text celebrates the wild Germanic Urwald and although the picture clearly represents ancient Germania, the text's 'Germania' is both ancient and contemporary. 


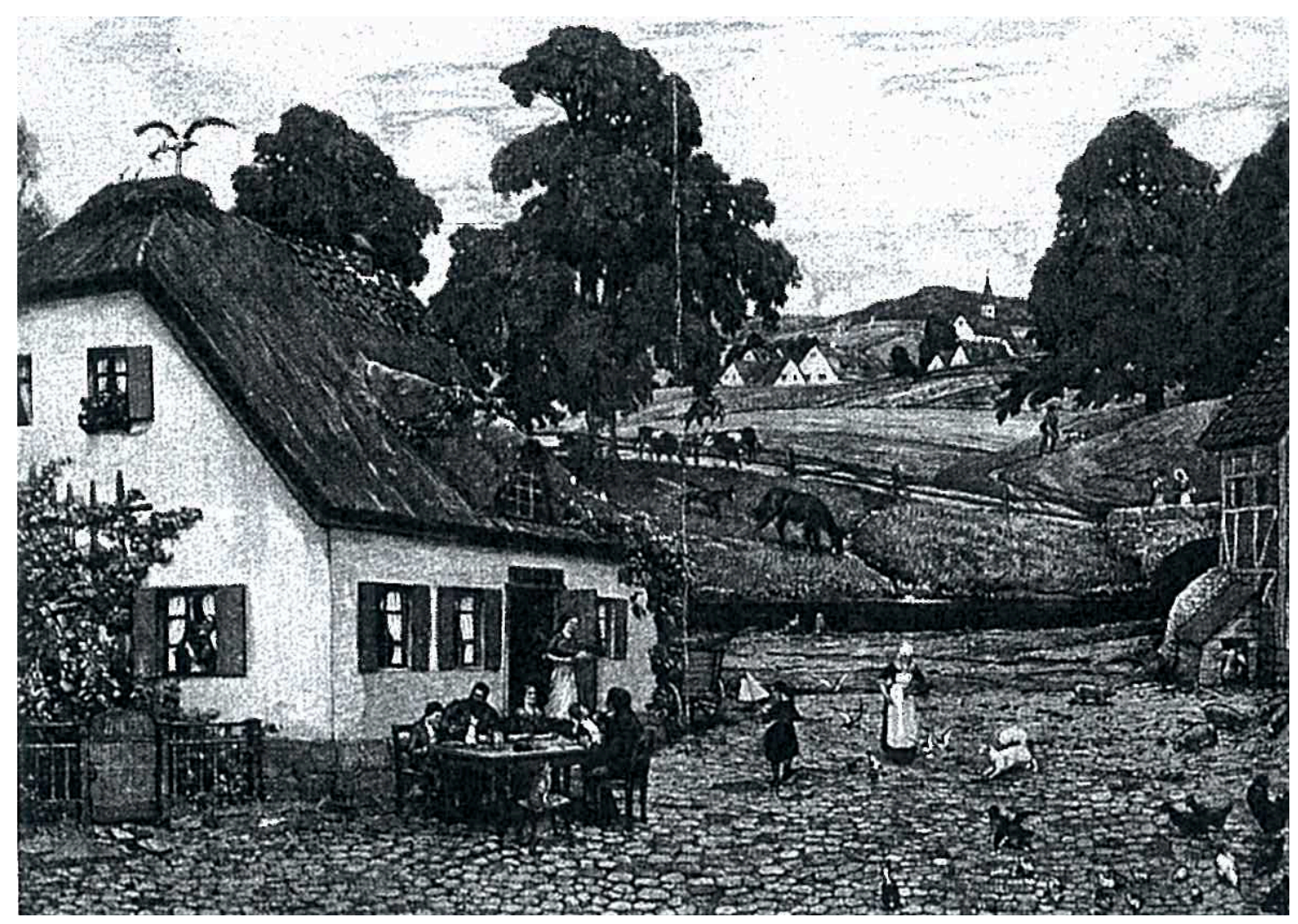

Figure 3: A black-and-white reproduction of the first colour picture in a German Latin textbook, Ludus Latinus I (1932) frontispiece. The first sight to greet the pupil embarking on the ancient foreign language was a storybook farmyard from an ideal rural German Heimat.

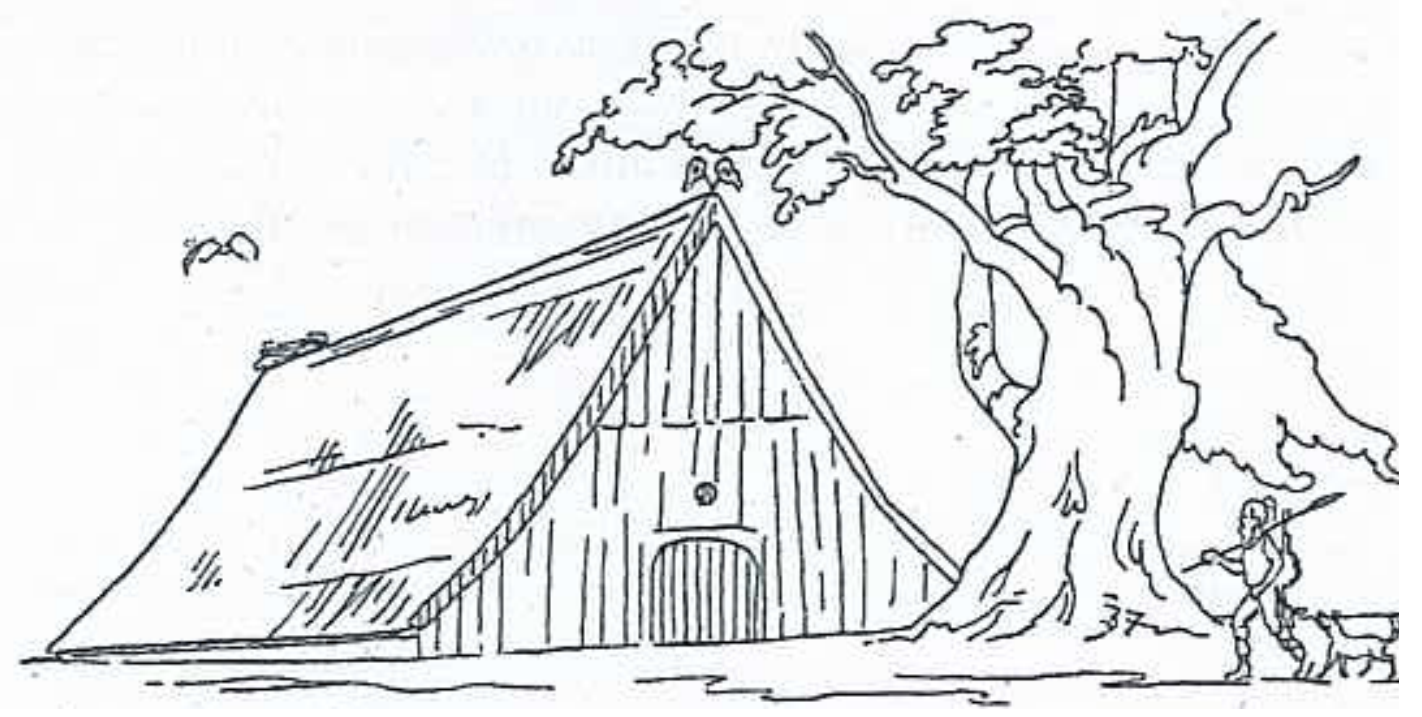

Figure 4: Ludus Latinus I (1932) page 9. A Germanic hunter returns to his simple but imposing homestead under, presumably, an oak, accompanied by his dog. 


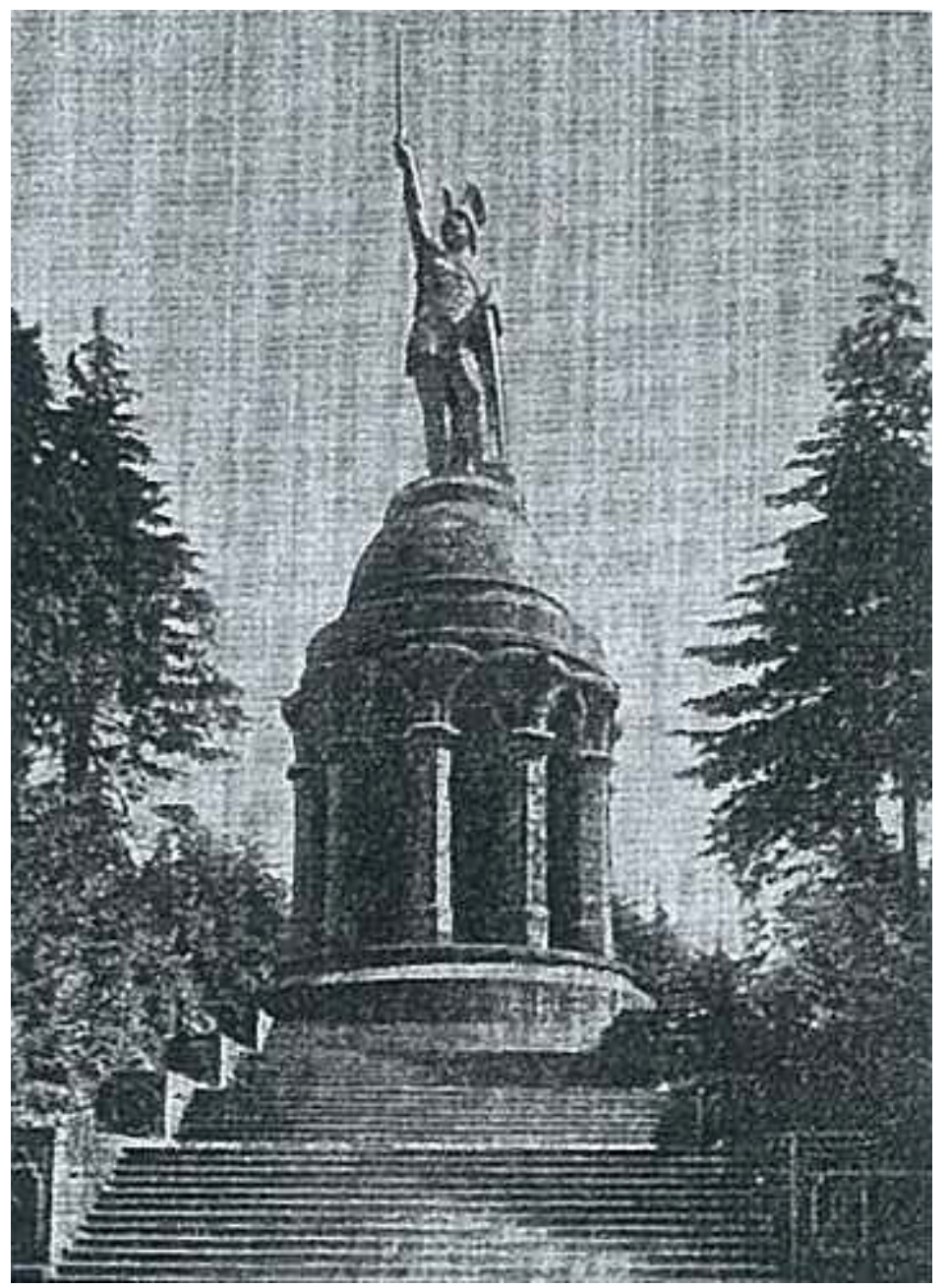

Figure 5: Lateinisches Unterrichtswerk I, Mader-Wecker, (1938) page 27. The Hermannsdenkmal illustrating a passage called Vor der Schlacht im Teutoburger Wald, an imaginary exhortation given by Arminius to his troops before the battle. 


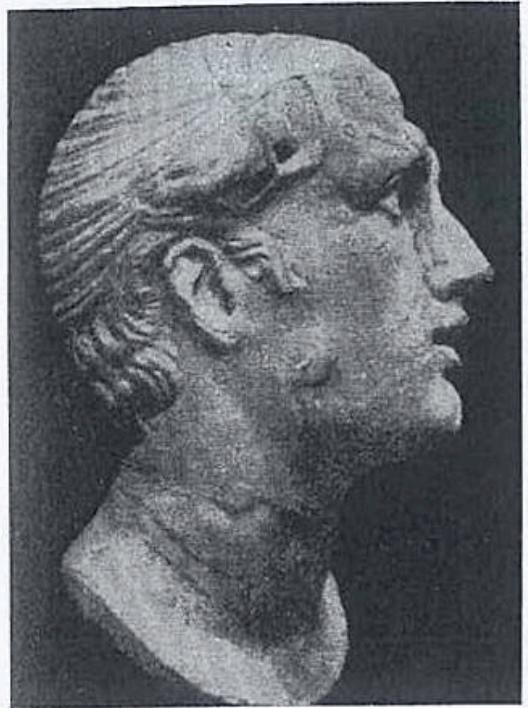

1. Sopf eines Eermanen.

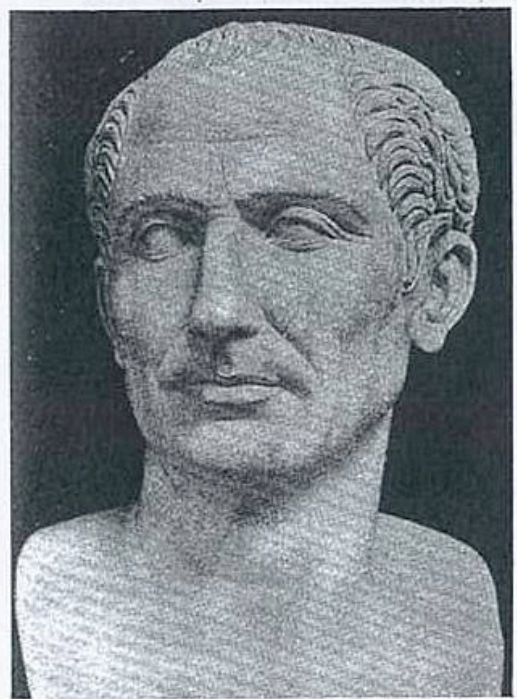

3. 厄. Julius 厄acjar.

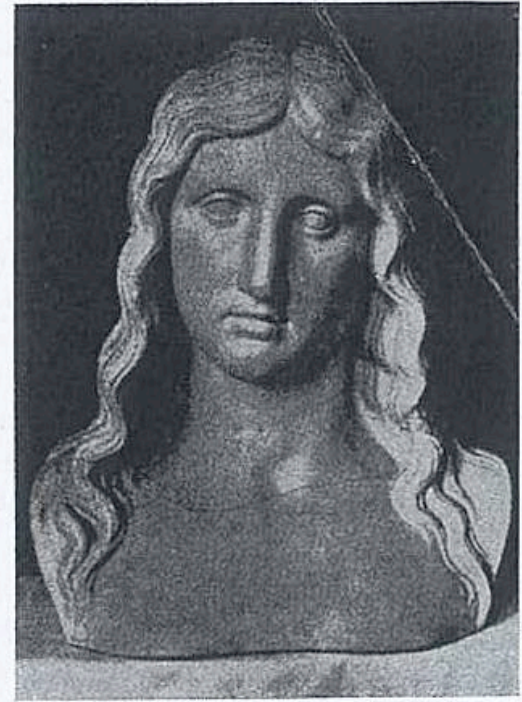

2. Sopf einer Germanin.

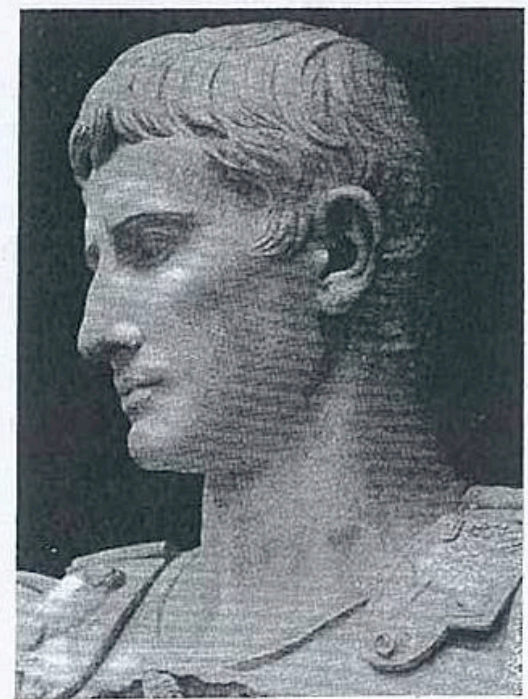

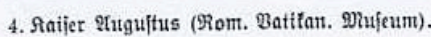

Exercit. Lat. [2818]

Figure 6: Exercitium Latinum (1941) page 149. The heading "Nordische Köpfe der Antike" is an example of the explicit use of Nazi racial vocabulary (as used in Erieiehung und Unterricht), particularly evident in this textbook. The Germani and Romans are presented as racially connected 'Nordic' races. 
b.

Die Sermanen: Fürrften unt ङefolge

Tacitus, rerum scriptor Romanus, multa de maioribus nostris narravit Principes Germanorum in bello plerumque magnam multitudinem comitum secum habebant. Multos comites habere non modo ius, sed etiam magnum decus erat. Comites una cum principibus pugnabant et periculum a capite principis arcebant. Vulnera in pectore habere honestum erat, in tergo habere inhonestum.

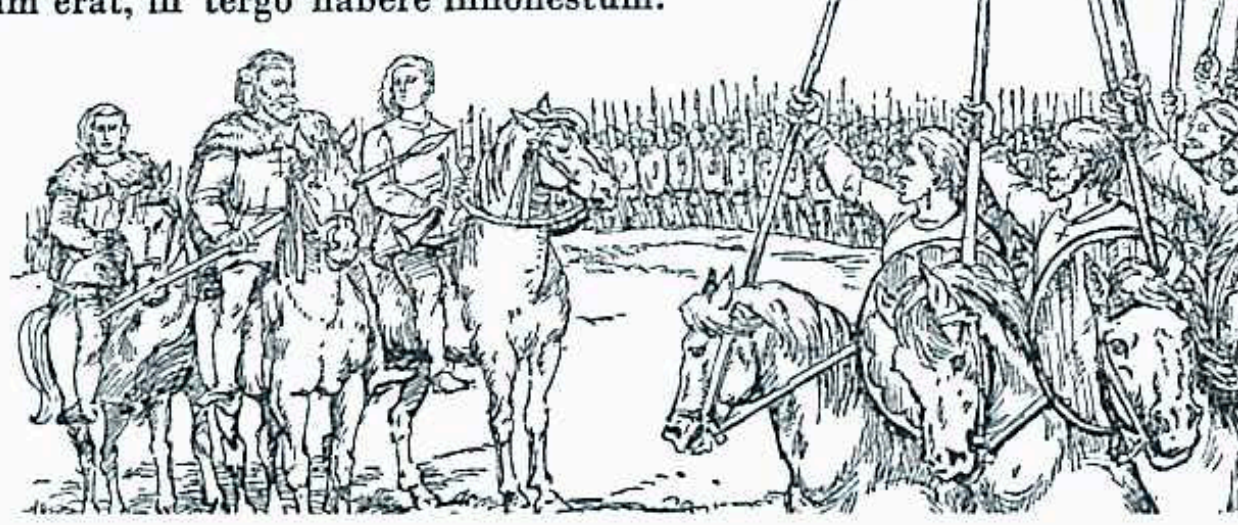

Figure 7: Ludus Latinus I B, ${ }^{11} 1963$. A text about Germanic chiefs and their warrior companions. The text is traditional in so far as it presents adapted statements from Tacitus' Germania as a series of facts. The warlike subject matter is also traditional. These barbarians, though warlike, appear less wild or 'barbaric' than those in figures 2 and 4. 


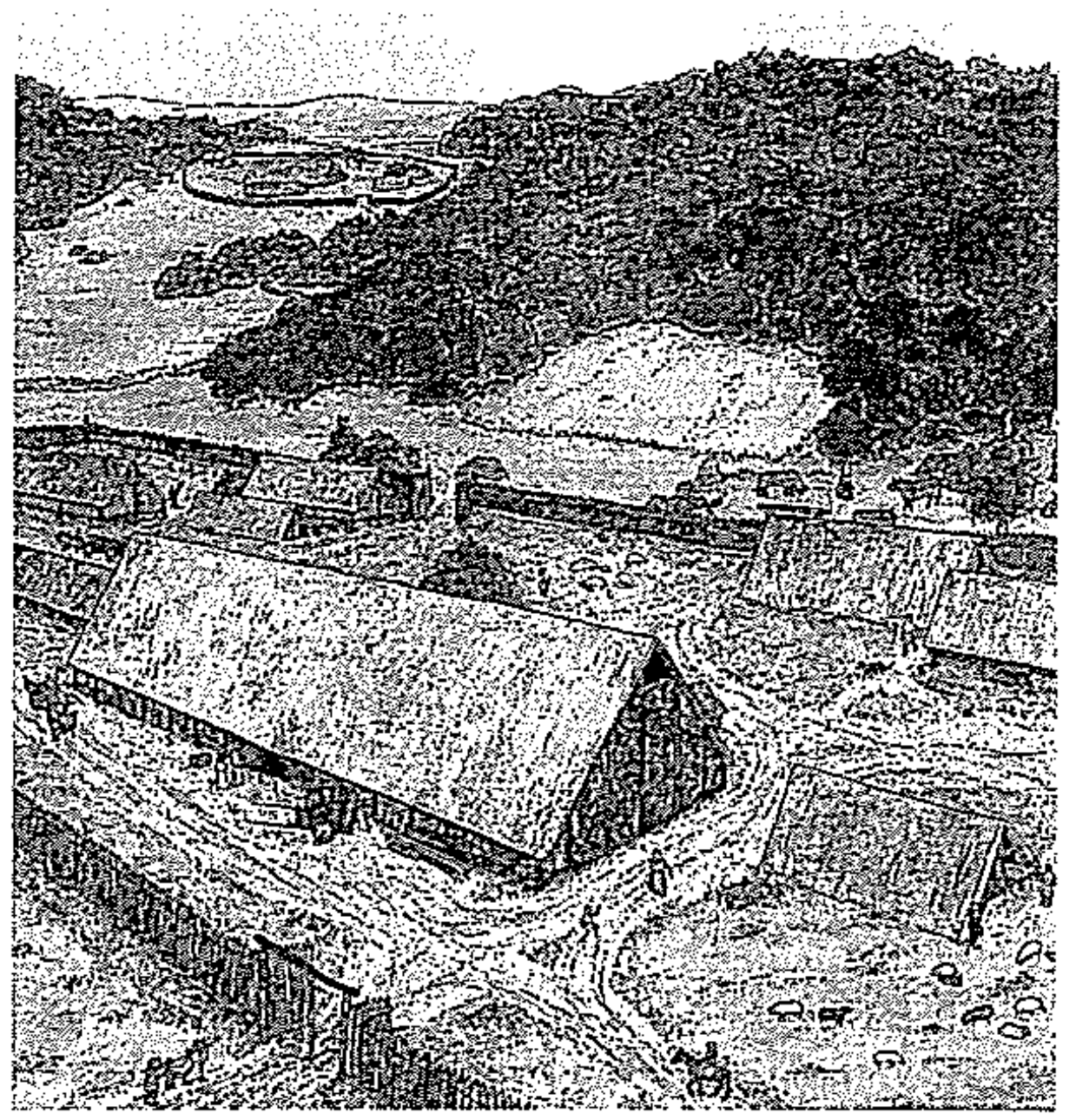

Germanische Bauernhöfe, 1.-2. Jh. n. Chr. Rekonstruktionszeichnung.

Figure 8: Salvete Alt, 69. The Germanic farmyards here portray a simple but settled life.

The forest is an important part of the landscape but not a looming presence. On the same page is a reminder of the warlike encounters between Romans and Germani: a relief of a

Germanic woman and child fleeing a Roman soldier, taken from Trajan's column. 


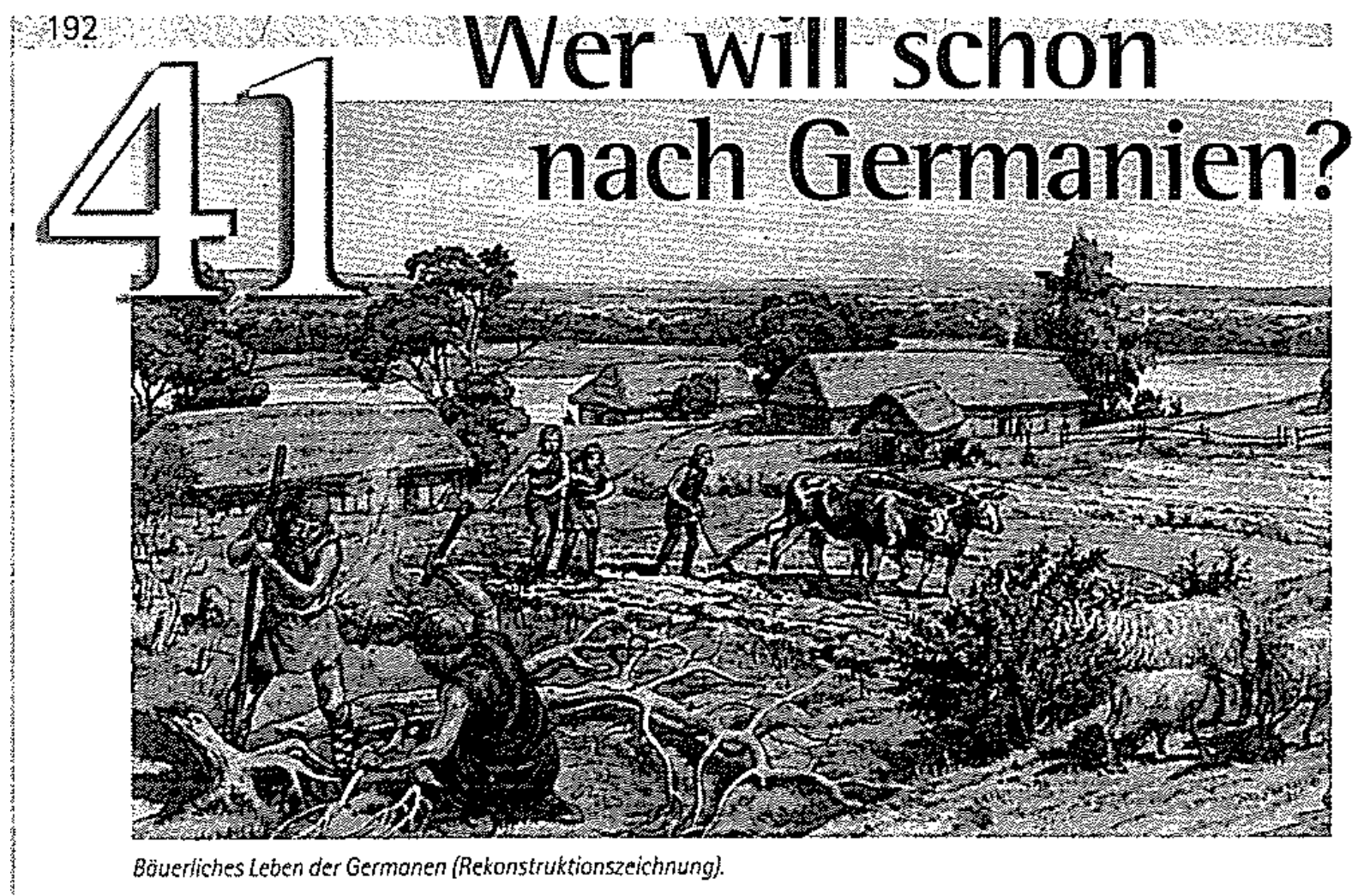

Figure 9: Prima (2004), 192. The Germani as farmers. There are no weapons or signs of hunting or warfare. The men on the left are in the process of clearing trees to create arable land. The children in the centre of the picture are sowing seeds, rather than engaging in any sort of preparatory war games.

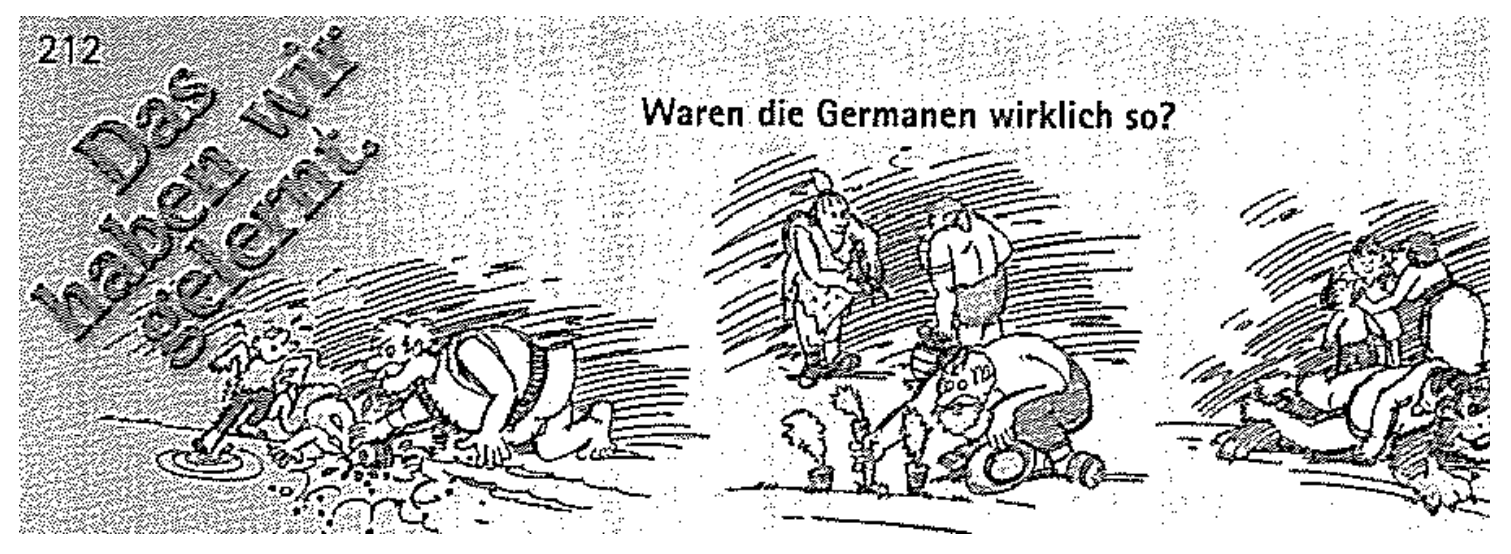

Figure 10: Prima (2004), 212. Cartoons representing Germanic stereotypes: a, the Germanic children were toughened from a young age and bathed in frigid water; $b$, the Germani were incapable of organised agriculture; c, sluggish Germanic men slept (often drunkenly) on bearskins. Prima invites a critical attitude towards Germanic clichés. 


\section{Bibliography}

\section{I: $\quad$ General bibliography \\ II: Ancient sources, translations and commentaries \\ III: Websites \\ IV: Lehrpläne \\ V: Textbooks and teachers' materials \\ VI: School editions of Germania}

\section{I: General bibliography}

Apel, Hans-Jürgen, 'Altsprachlicher Unterricht - Deutschland', in: Landfester ed., Der Neue Pauly (1999) Stuttgart, 114-119.

Apel, H., 'Humanistisches Gymnasium', in: Landfester ed., Der neue Pauly (1999) Stuttgart, 563-567.

Apel, H.-J., Bittner, S., Humanistische Schulbildung 1890-1945. Anspruch und Wirklichkeit der altertumskundlichen Unterrichtsfächer, Cologne/Weimar/Vienna, 1994.

Ash, Rhiannon, Tacitus (2006) London.

Bechert, Tilman, Römische Archäologie in Deutschland (2003) Stuttgart.

Beck, Heinrich, 'Tacitus' Germania und die deutsche Philologie', in Jahnkuhn, H., Timpe, D. edd. Beiträge zum Verständnis der Germania des Tacitus (1989) Göttingen, 155-179.

Becker, H., Kluchert, G., Die Bildung der Nation. Schule, Gesellschaft und Politik. vom Kaiserreich zur Weimarer Republik (1993) Stuttgart.

Benario, H.W., 'Recent Work on Tacitus 1994-2003’, Classical World, 98.3 (2005) 251-336.

Benario, H.W., 'Tacitus' Germania. A Third of a Century of Scholarship', Quaderni di Storia 17 (1983), 209-230.

Benario, H. trans. comm., Tacitus, Germany (1999), Warminster.

Böll, H., 'Tacitus. Germania', Die Zeit, 02/03/1979.

Breuilly, J., 'Urbanization and social transformation, 1800-1914' in: Ogilvie, S., Overy, R., edd., Germany. A New Social and Economic History. Volume III. Since 1800 (2003) London.

Büchner, Karl trans. comm. intr., Häussler, Reinhard ed., Tacitus, Agricola, Germania, Dialogus de Oratoribus, die historischen Versuche, ('1985) Stuttgart.

Bulwer, J. ed., Classics Teaching in Europe (2006) London.

Carrington, R. ed., Caesar's Invasions of Britain [Gallic War, Book IV, ch. 20-Book V, ch. 24] (1945) London.

Clasen, A., "Tacitus als Kritiker seiner Zeit: Ein Lektüreprojekt "Germania”, in: Maier ed., Tacitus in der Schule I. Vorscbläge zur Lektüre der Germania (1989) Bamberg, 5-78. 
Deißmann, M., trans. comm. intr., Caesar, De bello Gallico (2004) Stuttgart.

Dithmar, R. ed., Schule und Unterricht in der Endphase der Weimarer Republik (1993) Berlin.

Drexler, H., 'Die Germania des Tacitus', Gymnasium 59.1 (1952), 52-70.

Dürbeck, Helmut, 'Auspicia - Streit um ein neues Lehrbuch in Bayern', Forum Classicum, 48.1 (2005), 78-80.

Eckstein, F. A., Lateinischer und griechischer Unterricht (1887) Leipzig.

Eller, Gerhard, 'Die Germanen’ in: Höhn, W., Zink, N. edd., Handbuch für den

Lateinunterricht, Sekundarstufe I (1987) Frankfurt a.M., 310-318.

Fehrle, E., ed. trans. comm. intr., Tacitus, Germania (31939) Munich/Berlin.

Fischer, H.-J., Der altspracbliche Unterricht in der DDR. Entwicklung, Funktion und Probleme des Latein- und Griechischunterrichts von 1945 bis 1973 (1974) Paderborn.

Flemming, G., 'Auspicia' [review], Forum Classicum, 48.1 (2005), 75-78.

Fleming, Katie, 'Fascism' in: Kallendorf, C. ed. A Companion to the Classical Tradition (2007) Malden, 342-354.

Flessau, K-.I., Schule der Diktatur. Lehrplane und Schulbücher des Nationalsozialismus (1977) Munich.

Fritsch, A. 'Sprache und Inhalt lateinischer Lehrbuchtexte. Ein Unterrichtsgeschichtlicher Rückblick', in: Heistermann, W. ed. Abhandlungen aus der pädagogischen Hochschule Berlin 3 (1976), 116-169.

Fritsch, A., 'Die Lesestücke im lateinischen Anfangsunterricht. Ein Beitrag zur Geschichte des lateinischen Lehrbuchs', Der altsprachliche Unterricht 21.4 (1978), 6-37.

Fritsch, Andreas, 'Der Lateinunterricht in der Zeit des Nationalsozialismus. Organisation, Richtlinien, Lehrbücher', Der altsprachliche Unterricht 25.3 (1982), 20-56.

Fritsch, Andreas, 'Sachkunde im Anfangsunterricht. Ein Überblick', Der altsprachliche Unterricht 34.5 (1991), 4-22.

Fritsch, Andreas, ‘Schulbuch' in: Landfester, ed., Der neue Pauly (1999) Stuttgart, 1101-1105.

Fritsch, Andreas, 'Ein kritischer Rückblick auf den Dritten Humanismus in der ersten Hälfte des 20. Jahrhunderts' in: Wiersing, E. ed., Humanismus und Menschenbildung (2001) Essen, 224-242.

Fuhrmann, Manfred trans. comm. intr., Tacitus, Germania (1977) Stuttgart.

Fuhrmann, M. 'Altsprachlicher Unterricht zwischen Traditionspflege und Traditionsabbruch' in: Höhn, W., Zink, N., Handbuch für den Lateinunterricht, Sekundarstufe II (1979) Frankfurt a.M., 18-30. 
Fuhrmann, Mannfred, 'Die Germania in der Forschung der klassischen Philologie und im gymnasialen Unterricht', in: Jahnkuhn, H., Timpe, D. edd., Beiträge zum Verständnis der Germania des Tacitus (1989) Göttingen, 180-197.

Geiger, W., 'Staatsbürgerliche Bildung und Erziehung in der Endphase der Weimarer Republik' in: Dithmar, R. ed., Schule und Unterricht in der Endphase der Weimarer Republike (1993) Berlin, 1-20.

Glücklich, H.-J., Lateinunterricht. Didaktik und Methodik (1978) Göttingen.

Glücklich, H.-J., 'Germany' in: Bulwer, J. ed., Classics Teaching in Europe (2006) London, 5869.

Goodyear, F. ed. comm. intr., The Annals of Tacitus. Volume I: Annals 1.1-54 (1972)

Cambridge.

Goodyear, F. ed. comm. intr., The Annals of Tacitus. Volume II: Annals 1.55-81 and Annals 2 (1981) Cambridge.

Grabbe, C. D., Die Hermannsschlacht (1838), cited in reprint (1978) Detmold.

Günther, H., Rassengeschichte des hellenischen und römischen Volkes (1929) Munich.

Habenstein, E., 'Erinnerungen an Lateinbücher', Der altsprachliche Unterricht 6.5 (1963), 4250 .

Handford, S. trans. intr., Caesar, The Conquest of Gaul (1953) Harmondsworth.

Herd, E., Obermayer, A. ed., A Glossary of German Literary Terms (1983) Dunedin.

Hitler, A., Mein Kampf (1934) Munich.

Hoffmann, Friedrich, Der lateinische Unterricht auf sprachwissenschaftlicher Grundlage, Anregungen und Winke (1921) Leipzig/Berlin.

Hoffmann, Günther, 'Auspicia' [Review], Forum Classicum 47.3 (2004), 252-255.

Höhn, Wilhelm; Zink, Norbert edd..; Handbuch für den Lateinunterricht, Sekundarstufe I (1987) Frankfurt a.M.

Höhn, Wilhelm; Zink, Norbert edd..; Handbuch für den Lateinunterricht, Sekundarstufe II, (1979) Frankfurt a.M.

Huber, Heide, 'Eine römische Schule in Germanien. Anregungen und Material für Projektund Freiarbeit', Der altsprachliche Unterricht 41.2 (1998), 4-17.

Jahnkuhn, Herbert, 'Die Glaubwürdigkeit des Tacitus in seiner 'Germania' im Spiegel archäologischer Beobachtungen’, Gymnasium Beibeft 1 (1971), 142-151.

Jahnkuhn, Herbert; Timpe, Dieter edd., Beiträge zum Verständnis der Germania des Tacitus (1989) Göttingen.

Jäkel, W., Methodik des altsprachlichen Unterrichts (1966) Heidelberg. 
James, S., Röhrig, E. trans., Das alte Rom. Kultur und Alltag einer faszinierenden Epoche (2008) Hildesheim.

Joos, R, 'Adam, Arminius und Hermann in der Schule' in: Fuchs, K. et al. edd., Die Alamannen (1997) Stuttgart, 31-36.

Kallendorf, Craig ed. A Companion to the Classical Tradition (2007) Malden.

Kemkes, M. et al. ed., Am Rand des Imperiums. Der Limes. Grenze Roms zu den Barbaren (2002) Stuttgart.

Kennedy, E. comm. intr., Caesar, De Bello Gallico VI (2001) London.

Kipf, S., Herodot als Schulautor (1999) Cologne/Weimar/Vienna.

Kipf, S., Altsprachlicher Unterricht in der Bundesrepublik Deutschland (2006) Bamberg.

Kipf, S., 'Aut Caesar aut nihil?', Pegasus 2+3 (2006a), 28-46.

Klein, M. ed., Die Römer und ibr Erbe, Fortschritt durch Innovation und Integration (2003) Mainz.

Klinz, A., 'Die Rolle der Schulschriftsteller' in: Ahrens, E. ed., Lateinausbildung im Studienseminar (1963) Frankfurt a.M.

Koberg, Roland, Klaus Peymann: aller Tage Abenteuer; Biografie (1999) Berlin.

Koller, R., 'Die "Germania" - ein Politikum oder: Zur Geschichte des Mißbrauchs einer antiken Schrift', in: Maier ed., Tacitus in der Schule I. Vorschläge zur Lektüre der Germania (1989) Bamberg, 79-100.

Königer, Hans, 'Zur Methode der Tacitus-Lektüre am humanistischen Gymnasium', Der altsprachliche Unterricht 10.5 (1967), 97-124.

Kosinna, G., Die deutsche Vorgeschichte - eine hervorragend nationale Wissenschaft (1912) Würzburg; (1936) Leipzig.

Krüger, M., Hornig, G., Methodik des altspracblichen Unterrichts (1959) Frankfurt a.M.

Landfester, M., Humanismus und Gesellschaft im 19. Jabrbundert: Untersuchungen zur politischen und gesellschaftlichen Bedeutung der humanistischen Bildung in Deutschland (1988) Darmstadt.

Landfester, M. ed., Der neue Pauly: Ensyklopädie der Antike (1999) Stuttgart.

Landfester, M., 'Neuhumanismus’ in: Landfester ed., Der neue Pauly (1999) Stuttgart, 918925.

Lattmann, J., Geschichte der Methodik des lateinischen Elementarunterrichts seit der Reformation. Eine specialistische Ergänzung zur Geschichte der Pädagogik (1896) Göttingen.

Lund, Allan A. trans. comm. intr., Tacitus, Germania (1988) Heidelberg.

Lund, Allan, 'Versuch einer Gesamtinterpretation der 'Germania' des Tacitus, mit einem Anhang: Zu Entstehung und Geschichte des Namens und Begriffs 'Germani', Aufstieg und Niedergang der römischen Welt 33.3 (1991), 1858-1988. 
Lund, Allan, 'Kritischer Forschungsbericht zur 'Germania' des Tacitus', Aufstieg und

Niedergang der römischen Welt 33.3 (1991a), 1989-2222.

Lund, Allan, Germanenideologie im Nationalsozialismus (1995) Heidelberg.

Lund, Allan, 'Die Erfindung der Germanen', Der altsprachliche Unterricht 38.2 (1995a), 4-20.

Lund, Allan, 'Caesar als Ethnograph', Der altsprachliche Unterricht 39.2 (1996) 12-23.

Maier, F. ed., Tacitus in der Schule I, Vorschläge zur Lektüre der Germania (1989) Bamberg.

Maier, F., 'Die “Germania” im Rundfunk-Studio von Schülern einer 11. Jahrgangsstufe inszeniert', in: Maier, F. ed., Tacitus in der Schule I, Vorschläge zur Lektüre der Germania (1989a) Bamberg, 114-130.

Maier, F. ed., Tacitus in der Schule II, Vorschläge zur Lektüre der historischen Werke (1989b) Bamberg.

Martens, H., 'Gedanken zur Tacituslektüre', Der altsprachliche Unterricht 5.5 (1962), 52-83.

Mattingly, H. trans. comm. intr., Tacitus, On Britain and Germany (1948) West Drayton.

Mensching, E., Caesar und die Germanen im 20. Jahrbundert: Bemerkungen zum Nachleben des Bellum Gallicum in deutschsprachigen Texten (1980) Göttingen.

Morris, S., Experientia. A Modern Practice Book for “O” Level Latin, (1957) London/Toronto/ Wellington/Sydney.

Much, Rudolf comm. intr., Tacitus, Die Germania des Tacitus ('1937) Heidelberg.

Much, Rudolf comm. intr.; Lange, Wolfgang ed., Tacitus, Die Germania des Tacitus ( $\left.{ }^{3} 1967\right)$ Heidelberg.

Muhlack, Ulrich, 'Die Germania im deutschen Nationalbewußtsein vor dem 19. Jahrhundert', in: Jahnkuhn, Herbert; Timpe, Dieter edd., Beiträge zum Verständnis der Germania des Tacitus (1989) Göttingen, 128-154.

Müller, G., Das lateinische Übungsbuch des 19. Jahrbunderts in Deutschland [PhD dissertation] (1975) Universität Konstanz.

Nickel, R., 'Humanistisches Gymnasium und Nationalsozialismus', Paedagogica Historica 12.2 (1972), 485-503.

Nickel, R., 'Angepaßte Didaktik - Alte Sprachen und Nationalsozialismus', Pädagogische Rundschau, 38 Sonderbeft (1984), 85-102.

Norden, Eduard, Die germanische Urgeschichte in Tacitus Germania ( $\left.{ }^{4} 1959\right)$ Darmstadt.

Picht, G. "Zehn Thesen über die höhere Schule”, in Die Verantwortung des Geistes (1965) Olten/Freiburg im Breisgau, 85-99.

Picker, H. Hitlers Tischgespräche im Führerhauptquartier (1976) Stuttgart. 
Reeb, W. comm. Tacitus. Germania (1930) Leipzig/Berlin.

Riedel, V., 'Germany and German-Speaking Europe' in: Kallendorf, Craig ed. A Companion to the Classical Tradition (2007) Malden, 169-191.

Riess, W. \& C., 'The State of Latin Instruction in Germany Today' The Classical Journal $101.2(2005 / 6) 191-9$.

Rives, J. trans., comm. intr., Tacitus, Germania (1999) Oxford.

Römer, Ruth, Sprachwissenschaft und Rassenideologie (1989) Munich.

Rosenberg, A., Der Mythus des 20. Jabrbunderts (1934) Munich.

Rosenberger, Eugen, 'Germanien in PR-Präsentationen nach Tacitus', Der altsprachliche Unterricht 42.6 (1999), 51-54.

Schama, Simon, Landscape and Memory (1995) New York.

Scott-Kilvert, I. trans, Carter, J. intr., Cassius Dio, The Roman History: The Reign of Augustus (1987) London.

Schirok, Edith, 'Auspicia - „Als Feminina binde man die Frauen an die Bäume an!'‘ Forum Classicum, 48.1 (2005), 69-75.

Schlüter, W. ed., Kalkriese - Römer im Osnabrücker Land (1993) Bramsche.

Schulz, Meinhard-Wilhelm, "Tacitus: "Germania", Versuch einer kurzgefaßten Gesamtinterpretation', Der altsprachliche Unterricht 38.2 (1995), 21-39.

Schmidt, P., 'Latin Studies in Germany, 1933-1945: Institutional Conditions, Political Pressures, Scholarly Consequences' in: Harrison, S. ed., Texts, Ideas and the Classics (2001) Oxford, 285-300.

Scobie, A., Hitler's State Architecture. The Impact of Classical Antiquity (1990) University Park/London.

Shipley, Frederick trans. comm. intr., Velleius Paterculus, Compendium of Roman History (1924) Cambridge Mass./London.

Siebenborn, Elmar, 'Barbaren, Naturvölker, edle Wilde', Der altsprachliche Unterricht 41.4+5 (1998) 18-31.

Siebenborn, Elmar, 'Antike ethnologische Vorstellungen in der Entdeckungsliteratur', Der altsprachliche Unterricht 41.4+5 (1998a) 40-50.

Snell, B., Neun Tage Latein (1968) Göttingen.

Speer, A., Erinnerungen (1976) Frankfurt a.M.

Städele, Alfons, 'Neues von der Germania des Tacitus’, Anregung 36 (1990), 156-168.

Städele, A., 'Germania'-Interpretationen - gestern und heute' in: Neukam, P. ed. Dialog Schule und Wissenschaft 17, Motiv und Motivation (1993), 106-124. 
Städele, Alfons, 'Tacitus' Germania, Bericht über die Veröffentlichungen der Jahre 19761995 (Auswahl),', Gymnasium 104.6 (1997), 523-539.

Stray, Christopher, 'Education' in: Kallendorf, Craig ed. A Companion to the Classical Tradition (2007) Malden, 5-14.

Thieme, K-.D., 'Ora et labora! Anmerkungen zur Ideologie lateinischer Lehrbücher', Berliner Lehrer-Zeitung 8-9 (1969), 18-25.

Timpe, D., 'Einleitung' in: Jahnkuhn, Herbert; Timpe, Dieter edd., Beiträge zum Verständnis der Germania des Tacitus (1989) Göttingen, 7-15.

Timpe, D., 'Neue Gedanken zur Arminius-Geschichte' in: Timpe, D., Römisch-germanische Begegnung in der späten Republik und früben Kaiserzeit. Voraussetzungen - Konfrontationen Wirkungen (2006) Munich/Leipzig, 216-241, originally published in: Lippische Mitteilungen aus Geschicbte und Landeskunde 42 (1973), 5-30.

Timpe, D., 'Römische Geostrategie im Germanien der Okkupationszeit', in: Timpe, D., Römisch-germanische Begegnung in der späten Republike und frühen Kaiserzeit. VoraussetzungenKonfrontationen - Wirkungen (2006) Munich/Leipzig, 265-317.

Timpe, D., 'Die Schlacht im Teutoburger Wald: Geschichte, Tradition, Mythos' in: Timpe, D., Römisch-germanische Begegnung in der späten Republik und früben Kaiserzeit. VoraussetzungenKonfrontationen - Wirkungen (2006) Munich/Leipzig, 428-456, originally published in: Schlüter, W., Wiegels, R., Rom, Germanien und die Ausgrabungen von Kalkriese. Osnabrücker Forschungen zu Altertum und Antike-Rezeption 1 (1999) 717-737.

Trzaska-Richter, C., 'Das römische Germanenbild und wie man es benutzte', Der altsprachliche Unterricht, 36.6 (1993) 37-51.

Von Essen, Gesa, Hermannsschlachten: Germanen- und Römerbilder in der Literatur des 18. und 19. Jabrbunderts (1998) Göttingen.

Von Kleist, Heinrich, Die Hermannsschlacht (1808), cited in reprint (1963) Stuttgart.

Von See, Klaus, Deutsche Germanenideologie (1970) Frankfurt a.M.

Von See, Klaus, Sakraltheorie und Kontinuitätstheorie in der Germanenforschung (1972) Frankfurt a.M.

Von See, Klaus, Barbar, Germane, Arier (1994) Heidelberg.

Von See, Klaus, Ideologie und Philologie (2006) Heidelberg.

Waquet, Françoise; Howe, John trans., Latin, or the Empire of a Sign (2001) London.

Wellesley, K. trans. intr., Tacitus, The Histories (1975) Harmondsworth.

Wells, P., The Battle that Stopped Rome (2003) New York/London.

Westphalen, Klaus, 'Schlechte Auspizien für den Lateinunterricht', Forum Classicum 47.3 (2004), 255-257. 
Wilsing, N., Die Praxis des Lateinunterrichts, Teil II: Probleme der Lektüre (1964) Stuttgart.

Woodman, A., ed. comm. intr., Velleius Paterculus, The Tiberian Narrative (2.94-131), (1977) Cambridge.

\section{II: Ancient texts}

\section{Translations and commentaries are listed in section I (duplicated in some instances).}

Caesar; Deißmann, M., trans. comm. intr., De bello Gallico (2004) Stuttgart.

Caesar; Kennedy, E. comm. intr., De Bello Gallico VI (2001) London.

Cassius Dio; Scott-Kilvert, I. trans., Carter, J. intr., The Roman History: The Reign of Augustus (1987) London.

Tacitus; Goodyear, F. ed., Annals 1.1-54 (1972) Cambridge.

Tacitus; Goodyear, F. ed., Annals 1.55-81 and Annals 2 (1981) Cambridge.

Tacitus; Koestermann, E., Germania - Agricola - Dialogus de Oratoribus (1964) Leipzig.

Tacitus; Koestermann, E., Historiae (1961) Leipzig.

Tacitus; Lund, Allan A. ed., Germania (1988) Heidelberg.

Tacitus; Till, Rudolf, Handschriftliche Untersuchungen zu Tacitus Agricola und Germania: mit einer Photokopie des Codex Aesinas (1943) Berlin.

Tacitus; Winterbottom, M., Ogilvie, R. edd., Opera Minora (1975) Oxford.

Velleius Paterculus; Shipley, Frederick trans. comm. intr., Compendium of Roman History (1924) Cambridge Mass./London.

Velleius Paterculus; Woodman, A., ed., The Tiberian Narrative (2.94-131), (1977) Cambridge.

\section{III: Websites}

http://chronico.de/erleben/menschenorte/0000405

Online magazine article about re-enactment plans for the $2000^{\text {th }}$ anniversary of the battle in Teutoburg Forest, accessed 30/06/2008.

http://www.hermannschlachten07.de/informativ/varrusschlacht.htm

Website of artistic project HermannSchlachten07 by Künstler der Wagenhallen, Stuttgart, accessed 30/06/2008.

http://www.imperium-konflikt-mythos.de/

Website of 2009 exhibition for anniversary of 'Varrusschlacht', accessed 30/06/2008.

http://klassphil.philfak.uni-potsdam.de/denkwerk/

http://klassphil.philfak.uni-potsdam.de/denkwerk/Projektinformation_BrAnD.pdf

Websites pertaining to Robert Bosch Stiftung and Brandeburger Antike-Denkwerk, accessed 30/06/2008. 
http://www.osnabrueck-net.de/Touristik/kalkriese.html

The excavations at Kalkriese as tourist attraction, accessed 30/06/2008.

http://www.romanarmy.com

Forum for Roman-period battle re-enactment enthusiasts, accessed 30/06/2008.

http://www.standardsicherung.schulministerium.nrw.de/lehrplaene/upload/material/g8/

G8_L_Beispielsequenz_Vespucci.pdf

Proposed lesson plan for teaching Lorenzo di Pierfrancesco de Medici's Mundus Novus, accessed 30/06/2008.

IV: Lehrpläne

Richtlinien für höhere Schulen Preußens, Beilage zum Zentralblatt für die gesamte Unterrichtsverwaltung, 8 (1925) Berlin.

Erziebung und Unterricht in der böheren Schule. Amtliche Ausgabe des Reichs- und Preußischen Ministeriums für Wissenschaft, Erziehung und Volksbildung (1938) Berlin.

Senatsverwaltung für Bildung, Jugend und Sport, Rahmenlehrplan für die gymnasiale Oberstufe, Latein (2006) Berlin.

Senatsverwaltung für Bildung, Jugend und Sport, Rahmenlehrplan für die Sekundarstufe I. Latein 2./3. Fremdsprache (2006) Berlin.

http://download.bildung.hessen.de/unterricht/lernarchiv/lehrplaene/gymnasium/latein/ LPGymLatein.pdf

Hessisches Kultusministerium, Lehrplan. Latein. Gymnasialer Bildungsgang. Jahrgangsstufen 5 bis 13, last modified 20/02/2008, accessed 30/06/2008.

http://www.isb-gym8-lehrplan.de/contentserv/3.1/g8.de/index.php?StoryID=26287 Recommendations for year 7 of the 8-year Gymnasium in Bavaria, accessed 30/06/2008.

http://www.isb-gym8-lehrplan.de/contentserv/3.1/g8.de/index.php?StoryID=26292 Recommendations for Latin as first foreign language, year 7, Bavaria, accessed $30 / 06 / 2008$.

\section{V: Textbooks and teachers' materials}

The format is based on that used by Kipf (2006): texts are ordered by title. Editions of Ludus Latinus are listed chronologically.

Ars Latina, Lateinisches Unterrichtswerk für grundständiges Latein (I), auf der Grundlage der Ausgabe von 1965, Boekhorst, G., Reiff, A. (1983) Paderborn.

Auspicia, Unterrichtswerk, für Latein als zweite Fremdsprache (I: Roms Aufstieg zur Weltmacht), Karl, K. et al. (2005) Lappersdorf.

Auspicia, Unterrichtswerk für Latein als zweite Fremdsprache (II: Geschichte - Geschichten - Mythen), Karl, K. et al. (2005) Lappersdorf.

Auspicia, Unterrichtswerk für Latein als zweite Fremdsprache (III: Städte, Stätten und Personen), Karl, K. et al. ('2006) Lappersdorf. 
Cursus, Texte und Übungen, Einbändiges Unterrichtswerk für Latein (A), Boberg, B. et al. (2005) Bamberg/Munich.

Exercitia Latina für Latein als 2. Fremdsprache (IV: Übungs- und Lesebuch), Hornung, R. ("1974) Bamberg/Munich.

Exercitium Latinum, Lese- und Übungsbuch, Röttger, G. (1941) Leipzig/Berlin.

Experientia. A Modern Practice Book for "O" Level Latin, Morris, S. (1957) London/Toronto/ Wellington/Sydney.

Felix. Das Lateinbuch (A), Burdich, J. et al. (32004) Bamberg.

Felix. Das Sachbuch, Mühl, K. (21998) Bamberg.

Felix. Der Lehrerband. (A), Burdich, J. et al. (1996) Bamberg.

Fundamenta Linguae Latinae, Lateinisches Lebr-und Lesebuch (I A für die dritte Klasse der Oberschule), L. Voit, Zinsmeister, H. ("51942) Bamberg/Munich/Berlin/Reichenberg.

Lateinisches Übungsbuch im Anschluß an ein grammatisch geordnetes Vocabularium, (I: Sexta), Ostermann, C. ( $\left.{ }^{8} 1872\right)$ Leipzig.

Lateinisches Übungsbuch (I: Sexta), Ostermann, C., Müller, H. ('1896) Leipzig.

Lateinisches Unterrichtswerk I, Bornemann, E., (1949) Frankfurt a.M.

Lateinisches Unterrichtswerk II, Erklärungen und Anregungen für den Lehrer, Bornemann, E., [year unstated] Frankfurt a.M.

Lateinisches Unterrichtswerk (I C) [neu bearbeitet], Bornemann, E., Gebhardt, E. et al. edd. (1981) Frankfurt a.M.

Lateinisches Unterrichtswerk (I C), Krüger, M. ('1967) Frankfurt a. M.

Lateinisches Unterrichtswerk (II C), Krüger, M. ( $\left.{ }^{4} 1964\right)$ Frankfurt a. M.

Lateinisches Unterrichtswerk, Lese- und Übungsbuch (I), Mader, L., Wecker, O. (1938) Frankfurt a.M./Berlin.

Lateinisches Unterrichtswerk, Lese- und Übungsbuch (II), Mader, L., Wecker, O. (1940) Frankfurt a. M./Berlin.

Lingua Latina, Lateinisches Lehr-und Übungsbuch für Anstalten mit Lateinbeginn im 9. Schuljahr (31950) Berlin/Leipzig.

Ludus Latinus, Lateinisches Lese- und Übungsbuch für Sexta, Boesch, G., Michaelis, G. (1926) Leipzig/Berlin.

Ludus Latinus, Lateinisches Unterrichtswerk. für Schulen mit grundständigem Unterricht (III:Quarta), Salomon, G. $\left({ }^{6} 1932\right)$ Leipzig/Berlin.

Ludus Latinus, Lateinisches Unterrichtswerk für Schulen mit grundständigem Unterricht (II für Quinta), Wolff, F. ( $\left.{ }^{10} 1934\right)$ Leipzig/Berlin. 
Ludus Latinus, Übungsbuch (IV A), Röttger, G. (1936) Leipzig/Berlin.

Ludus Latinus (III / IV B), Röttger, G. ( $\left.{ }^{12 / 9} 1938\right)$ Leipzig/Berlin.

Ludus Latinus (I B), ( $\left.{ }^{11} 1963\right)$ Stuttgart.

Ludus Latinus, Lateinisches Lese- und Übungsbuch (III), Hartke, W., Michaelis, G. ('1966) Stuttgart.

Ludus Latinus. Lese- und Übungsbuch (II A), $\left({ }^{13} 1969\right)$.

Ostia, Lateinisches Unterrichtswerk. Band 1, Siewert, W. et al. (1985) Stuttgart.

Ostia, Lehrerkommentar, Weddigen, K. et al. (1988) Stuttgart.

Prima. Gesamtkurs Latein (A), Utz, C. et al. ('2004) Bamberg.

Prima, Gesamtkurs Latein. Lehrerheft, Utz, C. et al. (2006) Bamberg.

Prima. Prüfungen 2, Zu den Lektionen 22-58, Burdich, J., Czimmek, R. (2008) Bamberg.

Roma, Unterrichtswerk für Latein als 1. Fremdsprache (I: Römisches Leben), Ernstberger, R., Ramersdorfer H. (21984) Bamberg/Munich.

Roma, Unterrichtswerk für Latein als 1. Fremdsprache (II: Sagen, Fabeln und Legenden), Bosch, W., Häring, L., (21985) Bamberg/Munich.

Roma, Unterrichtswerk für Latein als 1. Fremdsprache (III: Geschichten aus der alten Welt), Hertel, G., Wojaczek, G. (1985) Bamberg/Munich.

Roma, Unterrichtswerk, für Latein als 1. Fremdsprache (IV: Römisches Denken, Reden und Handeln), Brumberger, H. et al. ('1986) Bamberg/Munich.

Salvete. Lehrerbandbuch, Schmidt, W. (1996) Berlin.

Salvete, Texte und Übungen (Gesamtband), Schmidt, W. et al. (1995) Berlin.

Salvete, Texte und Übungen (Gesamtband.), Althoff, U. (2007) Berlin.

\section{VI: School editions of Germania}

Haug, A., Tacitus. De Origine et Situ Germanorum Liber, (1988) Frankfurt a.M.

Schulz, M.-W., Tacitus. De Origine et Situ Germanorum (1993) Stuttgart/Düsseldorf/Berlin/ Leipzig.

Städele, A., Cornelius Tacitus. De Origine et Situ Germanorum (1983) Bamberg. 